\title{
Delineation of Areas Contributing Recharge to Wells in Central Long Island, New York, by Particle Tracking
}

By Paul E. Misut and Steven M. Feldman

U.S. GEOLOGICAL SURVEY

Open-File Report 95-703

Prepared in cooperation with the SUFFOLK COUNTY WATER AUTHORITY

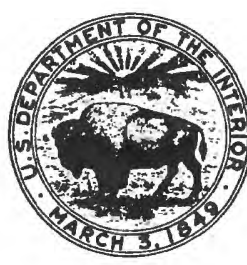




\section{U.S. DEPARTMENT OF THE INTERIOR BRUCE BABBITT, Secretary}

U.S. GEOLOGICAL SURVEY Gordon P. Eaton, Director

For additional information write to:

U.S. Geological Survey 2045 Route 112, Bldg. 4 Coram, NY 11727
Copies of this report may be purchased from:

U.S. Geological Survey Earth Science Information Center Open-File Reports Section P.O. Box 25286, MS 517 Denver Federal Center Denver, CO 80225 


\section{ERRATA}

Pg. 4, figure 2: Shift "GARDINERS CLAY" and "MONMOUTH GREENSAND" upward into adjacent geologic units.

Pg. 4, line 6: "10:1" should read "100:1"

Pg. 8, figure 9: Upper-glacial aquifer should be identified as aquifer containing the water table, and Gardiners Clay unit redrawn closer to sea level.

Pg. 9, lines 4-5: "calculated as direct runoff from precipitation minus evapotranspiration" should read "calculated as direct runoff and evapotranspiration subtracted from precipitation"

Pg. 15, table 2: Hydraulic conductivity range of Gardiners Clay/ Monmouth Greensand should read $0.313 \times 10^{-2}-0.515 \times 10^{-2}$.

Pg. 18, table 3: All outflows should be negative in "Flow rate" column.

Pg. 26, lines 19-20: "below the stage of a nearby stream" should read "at a nearby stream"

Pg. 27, line 17: "Vertical hydraulic conductivity" should read "Horizontal hydraulic conductivity" and "vertical hydraulic conductivity" should read "horizontal hydraulic conductivity" 



\section{CONTENTS}

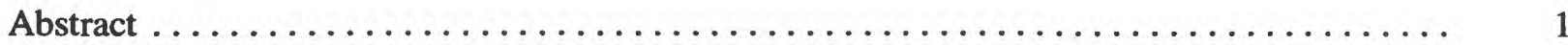

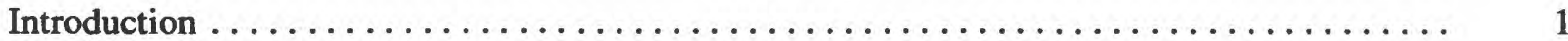

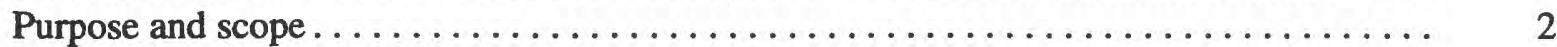

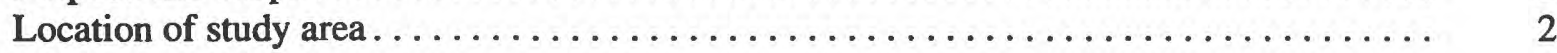

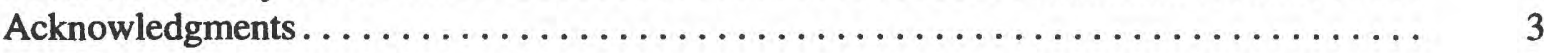

Ground-water-flow system in study area $\ldots \ldots \ldots \ldots \ldots \ldots \ldots \ldots \ldots \ldots \ldots \ldots \ldots$

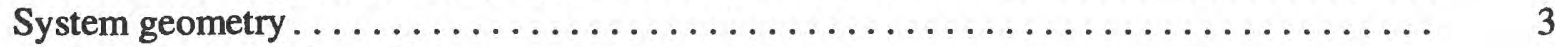

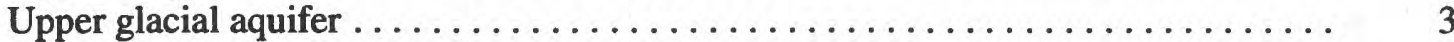

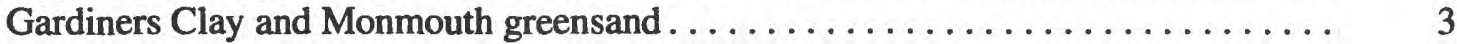

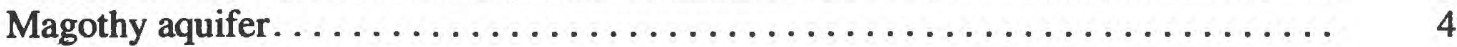

Raritan clay confining unit. . . . . . .

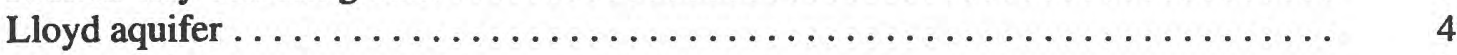

System boundaries. . . . . . . . . . . . . . . . . . .

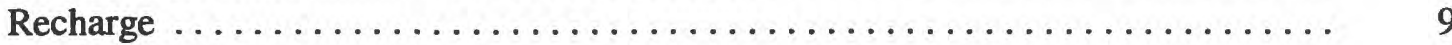

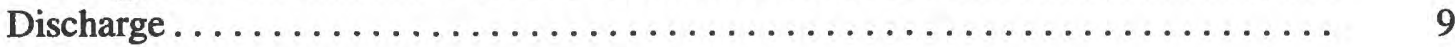

Ground-water-flow model . . . . . . . . . . . . . . . . . . . . . . . . . . 11

Model discretization and coupling. .......................... 11

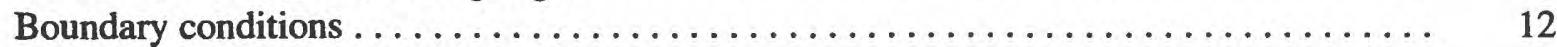

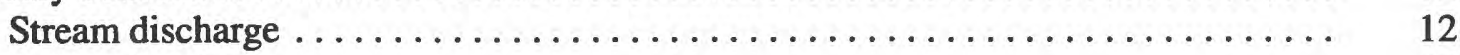

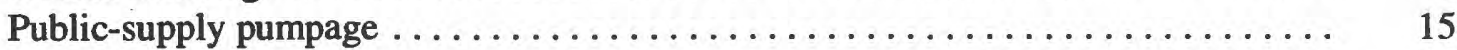

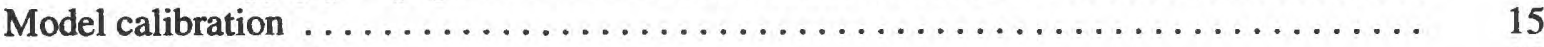

Model water budget. . . . . . . . . . . . . . . . . . . . . 18

Particle-tracking technique. . . . . . . . . . . . . . . . . . . . . . . . 19

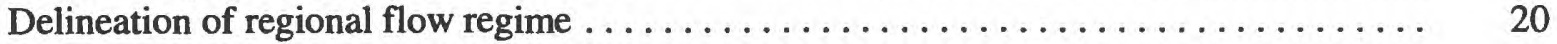

Factors that affect contributing areas. ........................ 24

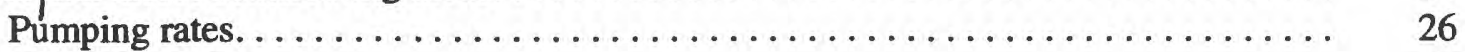

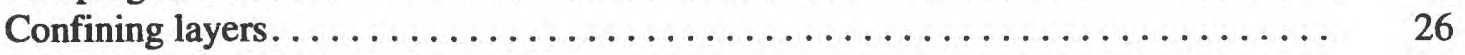

Proximity of well to flow boundaries. . . . . . . . . 26

Delineation of contributing areas to hypothetical wells. . . . . . . . . . . . . 26

Homogeneous zones of diversion (sites II, III) $\ldots \ldots \ldots \ldots \ldots \ldots \ldots \ldots \ldots \ldots$

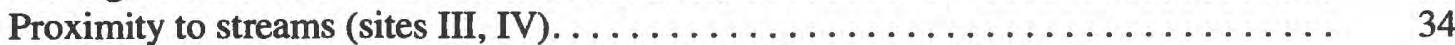

Proximity to shorelines (sites I, V)........................ 34

Heterogeneous zones of diversion (sites I, IV). . . . . . . . 34

Summary and conclusions $\ldots \ldots \ldots \ldots \ldots \ldots \ldots \ldots \ldots \ldots \ldots \ldots \ldots \ldots \ldots \ldots \ldots \ldots$

References cited..................................... 44

\section{FIGURES}

1. Map of Long Island, N.Y., showing location of study area in central Suffolk County and of the five hypothetical well sites. . . . . . . . . . . . . . . . . . . . . . .

2. Generalized north-south geologic section through study area............... 4 


\section{FIGURES (continued)}

3-8. Maps of study area showing:

3. 1983 water-table altitude and horizontal extent of Smithtown clay confining unit $\ldots \ldots \ldots 5$

4. Extent of Gardiners Clay and Monmouth greensand. . . . . . . . . . . . . . 5

5. Upper surface altitude of Magothy aquifer $\ldots \ldots \ldots \ldots \ldots \ldots \ldots \ldots \ldots \ldots \ldots \ldots \ldots \ldots \ldots \ldots$

6. Potentiometric-surface altitude of Magothy aquifer, March $1983 \ldots \ldots \ldots \ldots \ldots \ldots$

7. Upper surface altitude of Raritan clay confining unit $\ldots \ldots \ldots \ldots \ldots \ldots \ldots \ldots \ldots$

8. Potentiometric-surface altitude of Lloyd aquifer, March $1983 \ldots \ldots \ldots \ldots \ldots \ldots \ldots \ldots$

9. Generalized north-south hydrogeologic section through study area showing ground-water flow boundaries and directions of flow $\ldots \ldots \ldots \ldots \ldots \ldots \ldots \ldots \ldots \ldots \ldots \ldots$

10-11. Maps of study area showing:

10. Mean long-term annual recharge ........................ 10

11. Locations of surface-water bodies and hypothetical well sites $\ldots \ldots \ldots \ldots \ldots \ldots \ldots$

12. Grid of (A) regional Long Island model showing area represented by study-area model, and (B) study-area model showing principal geographic features of study area $\ldots \ldots \ldots \ldots \ldots$

13. Diagram showing model layering at eastern and western boundaries of study area ...... 13

14-18. Maps of study area showing:

14. Study-area-model recharge values as defined by regional Long Island model . . . . . . . 14

15. Head-dependent stream cells in study-area model $\ldots \ldots \ldots \ldots \ldots \ldots \ldots \ldots \ldots \ldots$

16. Simulated water-table altitude $($ model layer 1$) \ldots \ldots \ldots \ldots \ldots \ldots \ldots \ldots \ldots \ldots$

17. Simulated potentiometric surface in Magothy aquifer (model layer 5). . . . . . . 16

18. Simulated potentiometric surface in Lloyd aquifer (model layer 7 ) $\ldots \ldots \ldots \ldots \ldots$

19-20. Diagrams of:

19. Coordinate system and flow at faces of a MODFLOW finite-difference cell . . . . . . . . 19

20. Study-area model grid showing orientation of rows, columns, and layers as rendered in

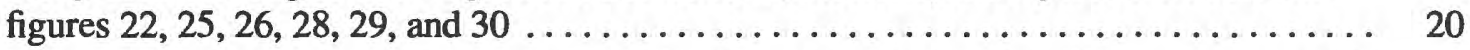

21. Map of study area showing recharge areas of the Magothy and Lloyd aquifers as generated by

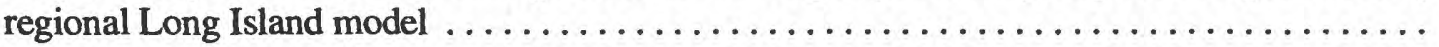

22-24. Diagrams of:

22. Model grid showing particle-tracking analyses of ground-water flowpaths along:

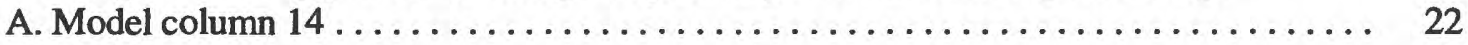

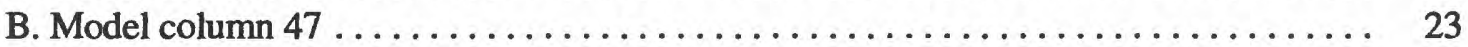

23. Zone of diversion and contributing area around a pumping well: (A) in plan view, and

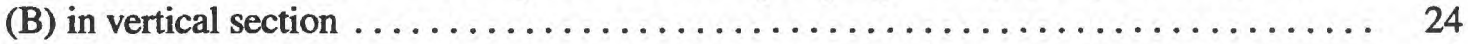

24. Particle flow: (A) in a single model cell specified as a weak sink, and

(B) a finely discretized cell specified as a strong sink . . . . . . . . . . . . . .

25. Study-area model grid at site II (Selden), near the regional ground-water divide, showing results of particle-tracking analyses for a hypothetical well screened in model layer 1:

A. Under unstressed (nonpumping) conditions . . . . . . . . . . . . . . 27

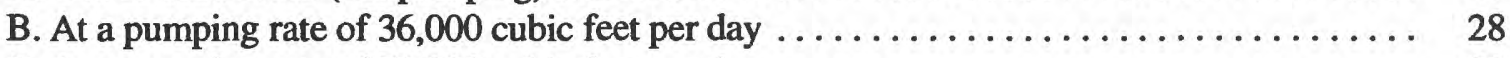

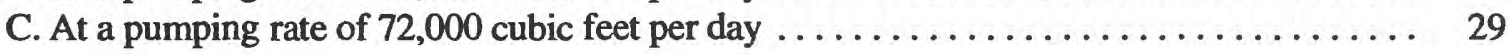


26. Study-area model grid at site III (Ridge), near the regional ground-water divide and adjacent to the Peconic River, showing results of particle-tracking analyses for a hypothetical well screened in model layers 4 and 6:

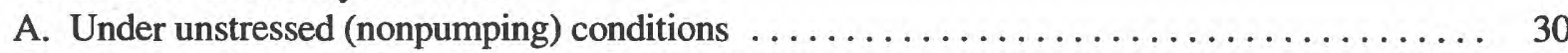

B. At a pumping rate of 36,000 cubic feet per day $\ldots \ldots \ldots \ldots \ldots \ldots \ldots \ldots \ldots \ldots \ldots \ldots \ldots \ldots$

C. At a pumping rate of 72,000 cubic feet per day from model layer $4 \ldots \ldots \ldots \ldots \ldots \ldots . \ldots \ldots$

D, At a pumping rate of 72,000 cubic feet per day from model layer $6 \ldots \ldots \ldots \ldots \ldots \ldots$

27. Maps of well site III (Ridge), near the Peconic River, showing cones of depression resulting from pumping rates of 36,000 and 72,000 cubic feet per day from model layer $1 \ldots \ldots \ldots \ldots$

28. Study-area model grid at site V (Moriches), near the southern shore, showing results of particle-tracking analyses for a hypothetical well screened in model layer 1:

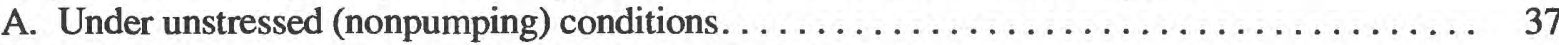

B. At pumping rates of 36,000 and 72,000 cubic feet per day $\ldots \ldots \ldots \ldots \ldots \ldots \ldots \ldots$

29. Study-area model grid at site IV (Patchogue), near the southern shore and adjacent to the Patchogue River, showing results of particle-tracking analyses for a hypothetical well screened in model layer 6:

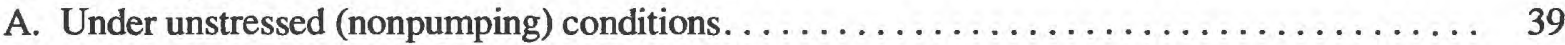

B. At a pumping rate of 36,000 cubic feet per day $\ldots \ldots \ldots \ldots \ldots \ldots \ldots \ldots \ldots \ldots \ldots \ldots \ldots \ldots$

C. At a pumping rate of 72,000 cubic feet per day $\ldots \ldots \ldots \ldots \ldots \ldots \ldots \ldots \ldots \ldots \ldots \ldots \ldots$

30. Study-area model grid at site I (Port Jefferson), $\mathrm{n}$ ear the northern shore, showing results of particle-tracking analyses for a hypothetical well screened in model layer 6:

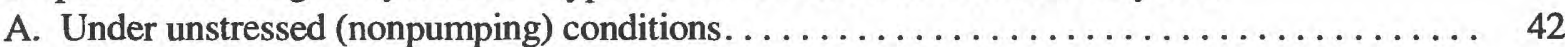

B. At pumping rates of 36,000 and 72,000 cubic feet per day $\ldots \ldots \ldots \ldots \ldots \ldots \ldots$

\section{TABLES}

1. Bays and streams represented by the study-area model $\ldots \ldots \ldots \ldots \ldots \ldots \ldots \ldots \ldots \ldots \ldots$

2. Range of hydraulic conductivity values used in regional model for each hydrologic unit

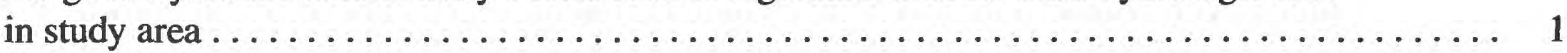

3. Simulated water budget for study area $\ldots \ldots \ldots \ldots \ldots \ldots \ldots \ldots \ldots \ldots \ldots \ldots \ldots \ldots \ldots$

4. Simulated discharges to selected surface-water bodies under unstressed (nonpumping) conditions, and the decrease in discharge that results from two pumping rates at hypothetical wells screened

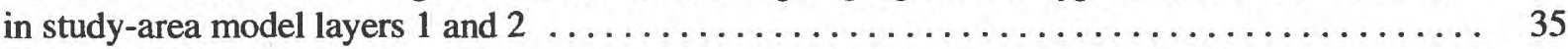

5. Public-supply-well locations in study-area model, Long Island, N.Y., and 1984-89 pumpage . . . . 46 
CONVERSION FACTORS, VERTICAL DATUM, AND ABBREVIATIONS

Multiply

\author{
foot (ft)
}

mile (mi)

square mile $\left(\mathrm{mi}^{2}\right)$

cubic foot per day $\left(\mathrm{ft}^{3} / \mathrm{d}\right)$

foot per day $(\mathrm{ft} / \mathrm{d})$

foot per mile $(\mathrm{ft} / \mathrm{mi})$
By

To Obtain

Length

0.3048

1.609

Area

2.590

Volume

28.32

liter per day

Hydraulic conductivity

0.3048

Gradient

0.1894 square kilometer

meter per day

meter

kilometer

meter per kilometer

Sea level: In this report, "sea level" refers to the National Geodetic Vertical Datum of 1929 (NGVD of 1929) - a geodetic datum derived from a general adjustment of the first-order level nets of the United States and Canada, formerly called Sea Level Datum of 1929. 


\title{
Delineation of Areas Contributing Recharge to Wells in Central Long Island, New York, by Particle Tracking
}

\author{
By Paul E. Misut and Steven M. Feldman
}

\begin{abstract}
Particle tracking was applied to a three-dimensional, seven-layer ground-water-flow model of a 270-square-mile area in central Long Island to delineate the recharge-contributing areas to five hypothetical well sites that represent a variety of hydrologic settings. These sites are (1) on the northern shore, (2) near the regional ground-water divide where a confining layer is present, (3) near the regional ground-water divide where no confining layer is present, (4) at the southern shore near the Patchogue River where a confining unit is present, and (5) at the southern shore near a tidal wetland where no confining unit is present. Ground-water flow at each site was simulated (1) under nonpumping conditions, and (2) at two pumping rates-36,000 and 72,000 cubic feet per day.

The model was calibrated to long-term, steady-state conditions and coupled to a previously developed Long Island regional model to obtain boundary flows and to define regional-scale system geometry. The study-area model has finer discretization than the regional model and can provide detailed flow-path resolution in the well-site areas. Particletracking analyses showed that the size and shape of the contributing areas to wells and the directions of ground-water flow can be significantly affected by (1) the presence or absence of a confining unit; (2) proximity to flow boundaries, such as streams, the shore, the saltwater-freshwater interface, and public-supply wells; and (3) pumping rates.
\end{abstract}

\section{INTRODUCTION}

Long Island's aquifer system is the sole source of potable water for the 2.6 million inhabitants of Nassau and Suffolk Counties (fig. 1). Public-supply pumping has created flow gradients that have increased the threat of aquifer contamination from surface sources and from saltwater encroachment. Public awareness of the need to protect the ground-water resources from further degradation has given rise to management efforts to delineate the water-table-recharge areas (contributing areas) that correspond to public-supply wells and to limit contaminant loading in these areas. Accurate delineation of contributing areas is essential because management strategies that are based on overly simplified characterizations could result in needless protection of areas that do not contribute water to wells and failure to protect areas that do. Flowpath analysis through use of computer models is useful for delineating contributing areas because the models can incorporate complexities of the ground-water flow system and thereby give more reliable results than simpler methods of estimation.

In October 1989, the U.S. Geological Survey (USGS), in cooperation with the Suffolk County Water Authority (SCWA), began a 3-year study to delineate the contributing areas to public-supply wells and identify the factors that affect the size and shape of the contributing areas. As part of the study, à groundwater-flow model was developed that incorporates a hypothetical pumping well in five selected areas, each representing a specific type of hydrologic setting. Ground-water flow at each site was simulated under 
unstressed (nonpumping) conditions at selected screen depths and at two pumping rates- $-36,000 \mathrm{ft}^{3} / \mathrm{d}$ and $72,000 \mathrm{ft}^{3} / \mathrm{d}$. A particle-tracking technique was applied to delineate the contributing area to each well. Site I (Port Jefferson) is on the northern shore, site II (Selden) is near the regional ground-water divide and has a confining unit, site III (Ridge) is near the ground-water divide but lacks a confining unit, site IV

(Patchogue) is at the southern shore near a river and has a confining unit, and site V (Moriches) is at the. southern shore near a minor stream and lacks a confining unit (fig. 1).

Objectives of the study were to (1) delineate contributing areas associated with each well site, (2) describe the effect of pumping on ground-water discharge and on the shape and size of the contributing area, and (3) evaluate the limitations of the particle-tracking technique that result from "weak-sink" conditions.

\section{Purpose and Scope}

This report presents a series of maps and vertical sections that depict stratigraphic relations and a set of model-grid diagrams showing particle flowpaths at the five hypothetical well sites in central Long Island. It describes (1) the hydrologic setting at the five sites, (2) the modeling approach and particle-tracking technique, (3) results of the particle-tracking analyses, and (4) the effects of confining units, nearby discharge boundaries, well-screen depth, and pumping rate on the size and shape of the contributing areas.

\section{Location of Study Area}

The study area (fig. 1) encompasses $270 \mathrm{mi}^{2}$ in the Town of Brookhaven, in central Suffolk County. It is ideal for representation by a long-term, steady-state flow model because hydraulic stresses from outside the study area are stable and do not substantially affect lateral boundary flow. Although the diversion of more

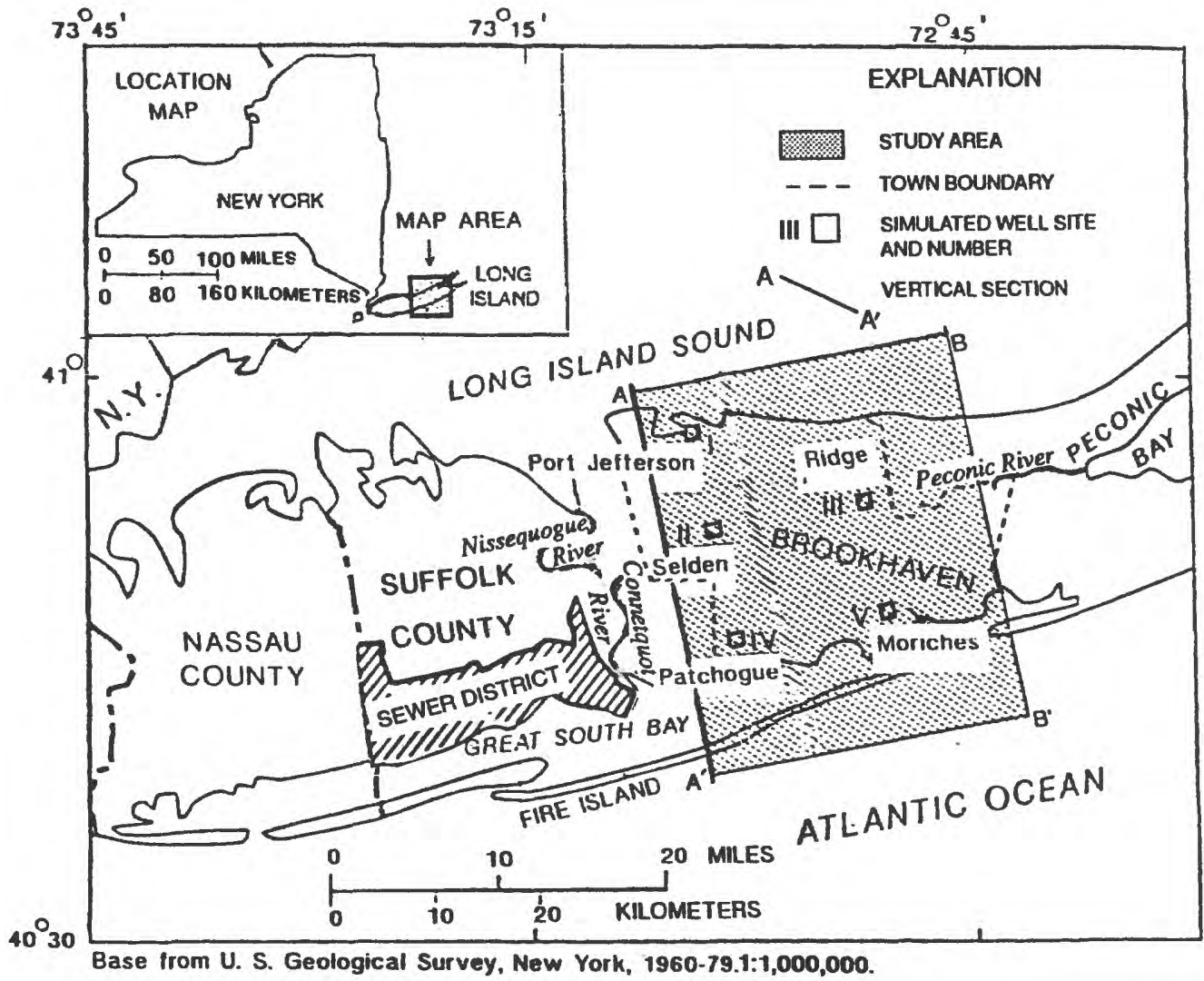

Figure 1. Location of study area in central Suffolk County, Long Island, N.Y., and of the five hypothetical well sites. 
than $40 \mathrm{ft}^{3} / \mathrm{s}$ of potential ground-water recharge to ocean outfall through the sanitary sewer system of southwestern Suffolk County (fig. 1) has been estimated to cause as much as $8 \mathrm{ft}$ of water-table drawdown locally (Buxton and Reilly, 1985), two of Long Island's largest streams-the Connetquot and Nissequogue Rivers (fig. 1)-lie between the sewer district and the study area and form a ground-water discharge area that extends into the center of the island, effectively stabilizing ground-water levels. The eastern boundary of the study area is mostly undeveloped pine barrens with stable ground-water conditions.

\section{Acknowledgments}

Thanks are extended to Julian Soren (USGS, retired) for providing information on the hydrogeologic framework of the area.

\section{GROUND-WATER-FLOW SYSTEM IN STUDY AREA}

Quantitative description of the ground-water-flow system requires (1) delineation of the extent, thickness, and hydraulic characteristics of the aquifers and confining units, and (2) definition of system boundary conditions, specifically (a) recharge associated with infiltration of precipitation and lateral inflow of ground water, and (b) discharge to gaining streams and the shore, and as subsea outflow and well pumpage. Characteristics of these flow-system components within the study area are described below.

\section{System Geometry}

The study area is underlain by unconsolidated materials of Pleistocene and Cretaceous age that range in thickness from about $800 \mathrm{ft}$ along the north shore to about 2,000 ft along the south-shore barrier beach (Fire Island) (fig. 1). The unconsolidated deposits are underlain by folded and faulted crystalline Precambrian bedrock. The bedrock surface dips southeastward at about $70 \mathrm{ft} / \mathrm{mi}$ (Smolensky and others, 1989).

A generalized north-south section through the study area is shown in figure 2. The upper Pleistocene hydrologic units consist of the upper glacial aquifer, the Smithtown clay confining unit, and the Gardiners Clay. These are underlain by Upper Cretaceous units, which are the Monmouth greensand, the Magothy aquifer, the Raritan clay confining unit, and the Lloyd aquifer. Hydrogeologic characteristics of the major units are described in the following paragraphs.

\section{Upper glacial aquifer}

The upper glacial aquifer consists of upper Pleistocene deposits of clay, sand, and gravel from the Ronkonkoma and Harbor Hill stades of the Wisconsin glaciation. The Smithtown clay unit was deposited between the Ronkonkoma and Harbor Hill moraines (fig. 2). Glacial outwash plains lie south of the Ronkonkoma terminal moraine and in the intermorainal zone. Horizontal hydraulic conductivity of the aquifer is about $270 \mathrm{ft} / \mathrm{d}$; average horizontal-to-vertical anisotropy is 10:1 (McClymonds and Franke, 1972). The water table is within the upper glacial aquifer; its altitude, as measured in 1983 (Doriski, 1986) is depicted in figure 3. The largest head values, about $65 \mathrm{ft}$ above sea level in 1983, are above the Smithtown clay unit near the ground-water divide. Heads decline to sea level at either shore. The steepest water-table slope $(30 \mathrm{ft} / \mathrm{mi}$ ) is in clayey moraine deposits north of the ground-water divide, and the gentlest slope ( 8 to $10 \mathrm{ft} / \mathrm{mi}$ ) is in outwash deposits south of the Ronkonkoma terminal moraine.

\section{Gardiners Clay and Monmouth greensand}

The Gardiners Clay and Monmouth greensand (fig. 4) are contiguous units consisting mostly of marine clay and silt. Average vertical hydraulic conductivity of both units is $0.001 \mathrm{ft} / \mathrm{d}$ (Smolensky and others, 
1989). These units have a combined thickness of about $150 \mathrm{ft}$ at Fire Island and pinch out just north of the south shore of Long Island.

\section{Magothy aquifer}

The Magothy aquifer extends throughout the study area and consists of deltaic deposits of mainly sand with interbedded silt and clay layers. The aquifer's average horizontal hydraulic conductivity is $50 \mathrm{ft} / \mathrm{d}$ (Franke and Cohen, 1972), and its horizontal-to-vertical anisotropy is estimated to be 10:1 (Smolensky and others, 1989). Aquifer thickness varies locally as a result of glacial erosion and ranges from about $100 \mathrm{ft}$ beneath the intermorainal zone to $800 \mathrm{ft}$ or more beneath the outwash plain (fig. 2). The surface configuration of the Magothy is depicted in figure 5. In the southern part of the study area, the Magothy is overlain by the Gardiners Clay/Monmouth greensand. The potentiometric-surface altitude in the Magothy, as measured in March 1983 (Doriski, 1986), is depicted in figure 6.

\section{Raritan clay confining unit}

The Raritan clay confining unit overlies and confines the Lloyd aquifer throughout the study area. Thickness ranges from 100 to $200 \mathrm{ft}$, and average vertical hydraulic conductivity is about $0.001 \mathrm{ft} / \mathrm{d}$ (Smolensky and others, 1989). The upper surface altitude of the Raritan clay is depicted in figure 7.

\section{Lloyd aquifer}

The Lloyd aquifer overlies bedrock. It ranges in thickness from 200 to $400 \mathrm{ft}$ and has a horizontal hydraulic conductivity of $40 \mathrm{ft} / \mathrm{d}$ (Franke and Cohen, 1972). Horizontal-to-vertical anisotropy is estimated to be 10:1 (McClymonds and Franke, 1972). The potentiometric-surface altitude in the Lloyd, as measured in March 1983 (Doriski, 1986), is depicted in figure 8.

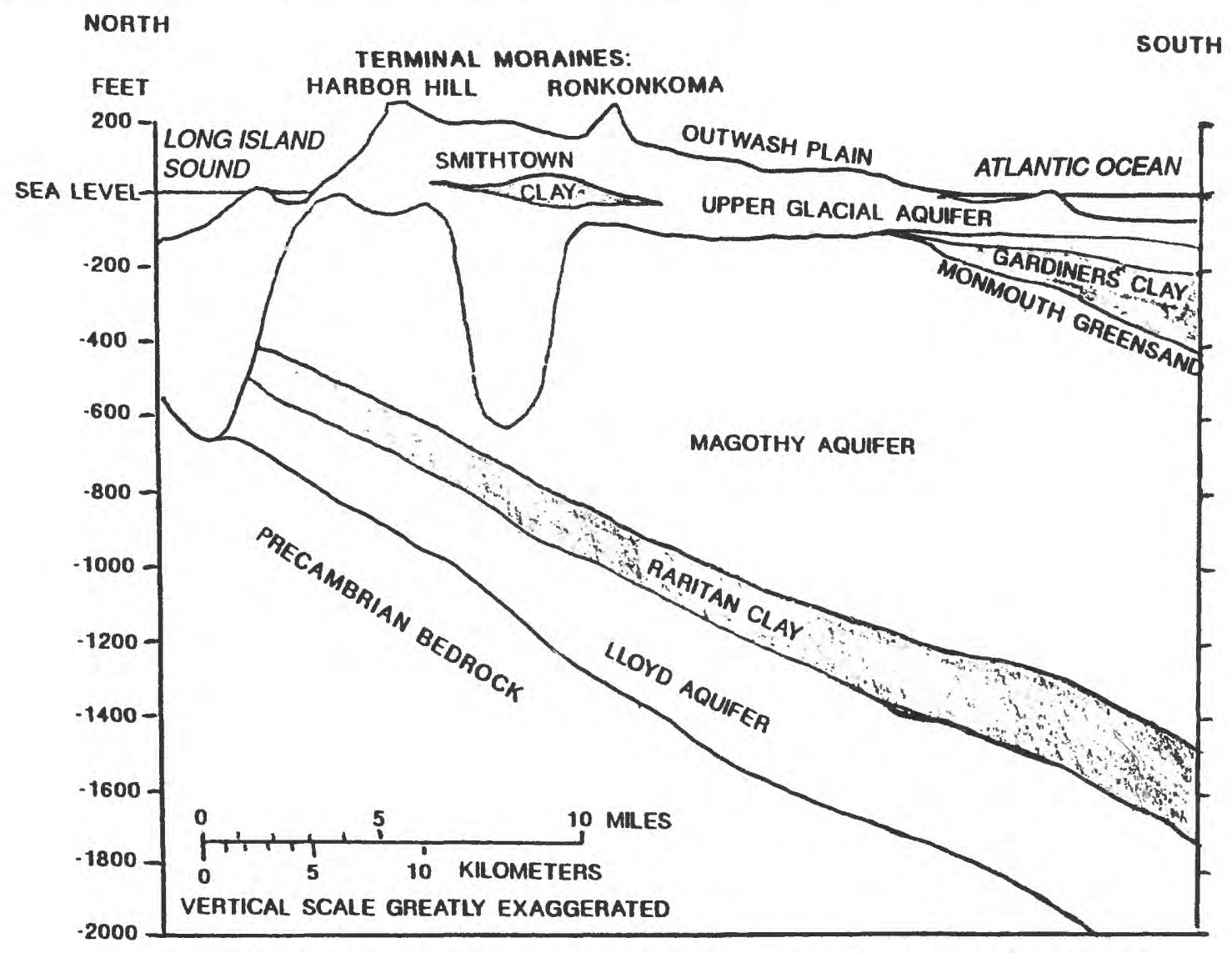

Figure 2. Generalized north-south geologic section through study area, Long Island, N.Y. (Modified from Smolensky and others, 1989, sheet 1.) 


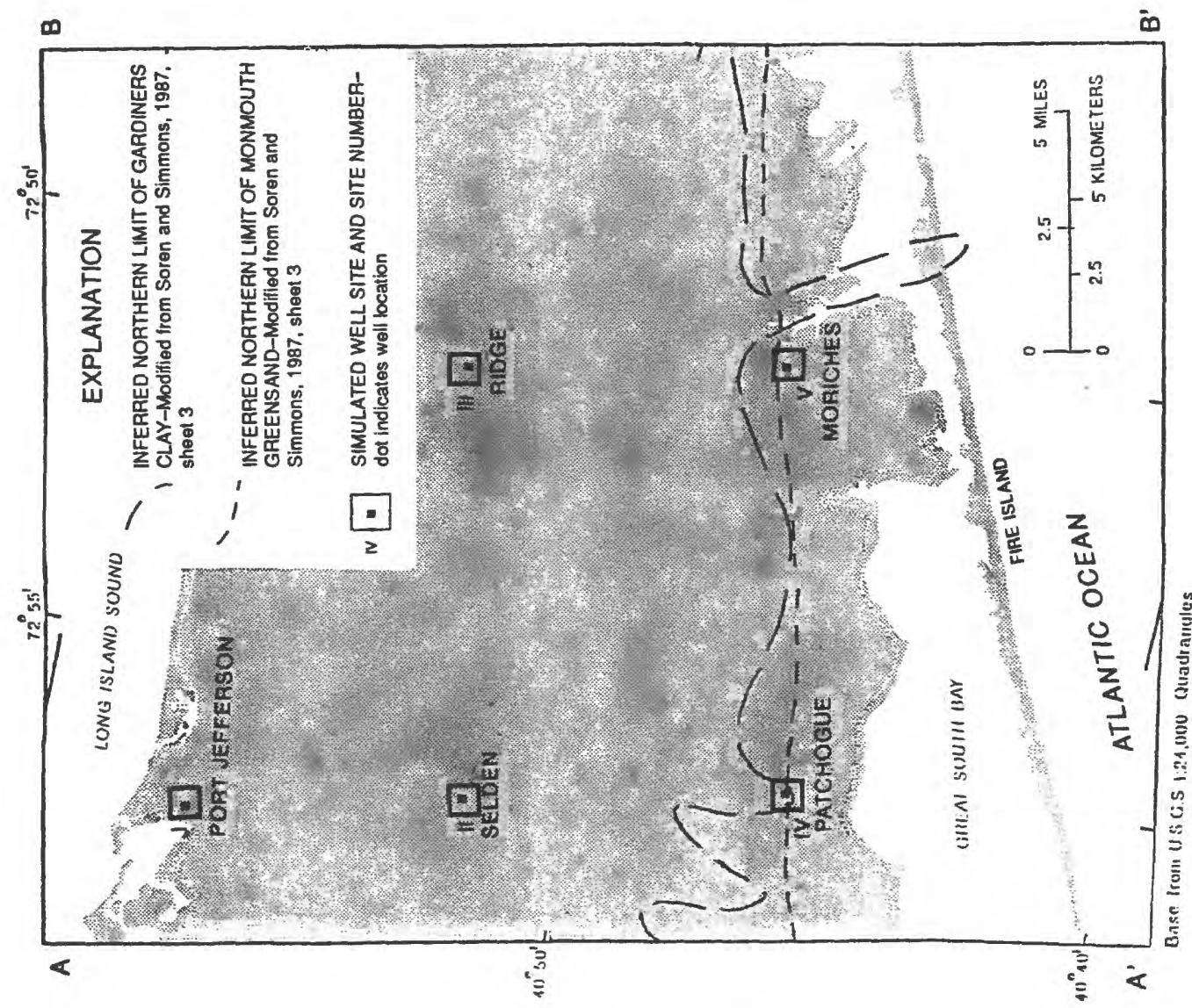

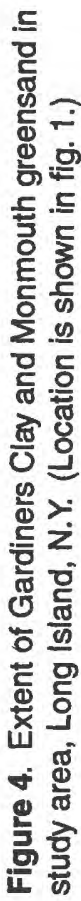

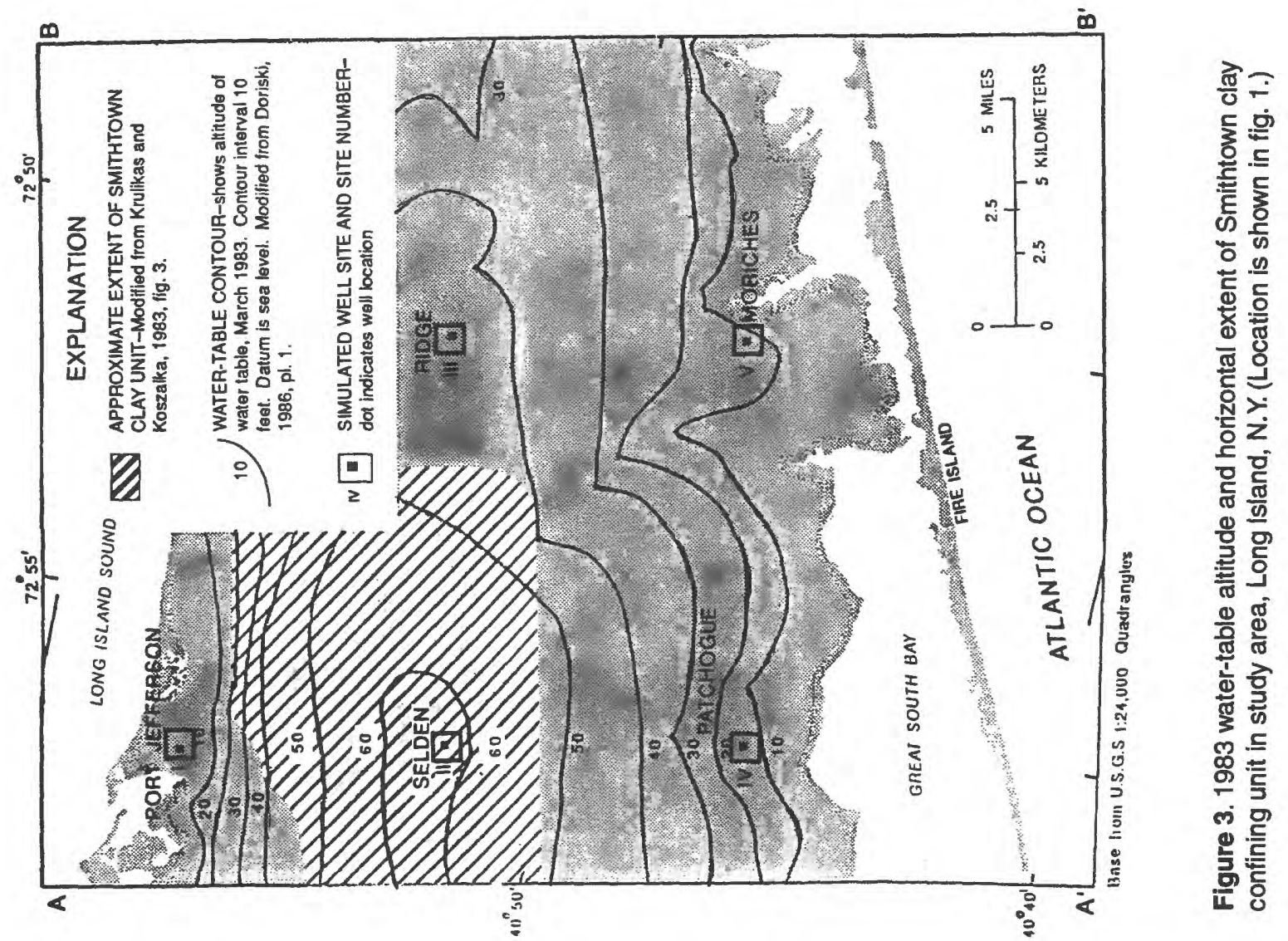



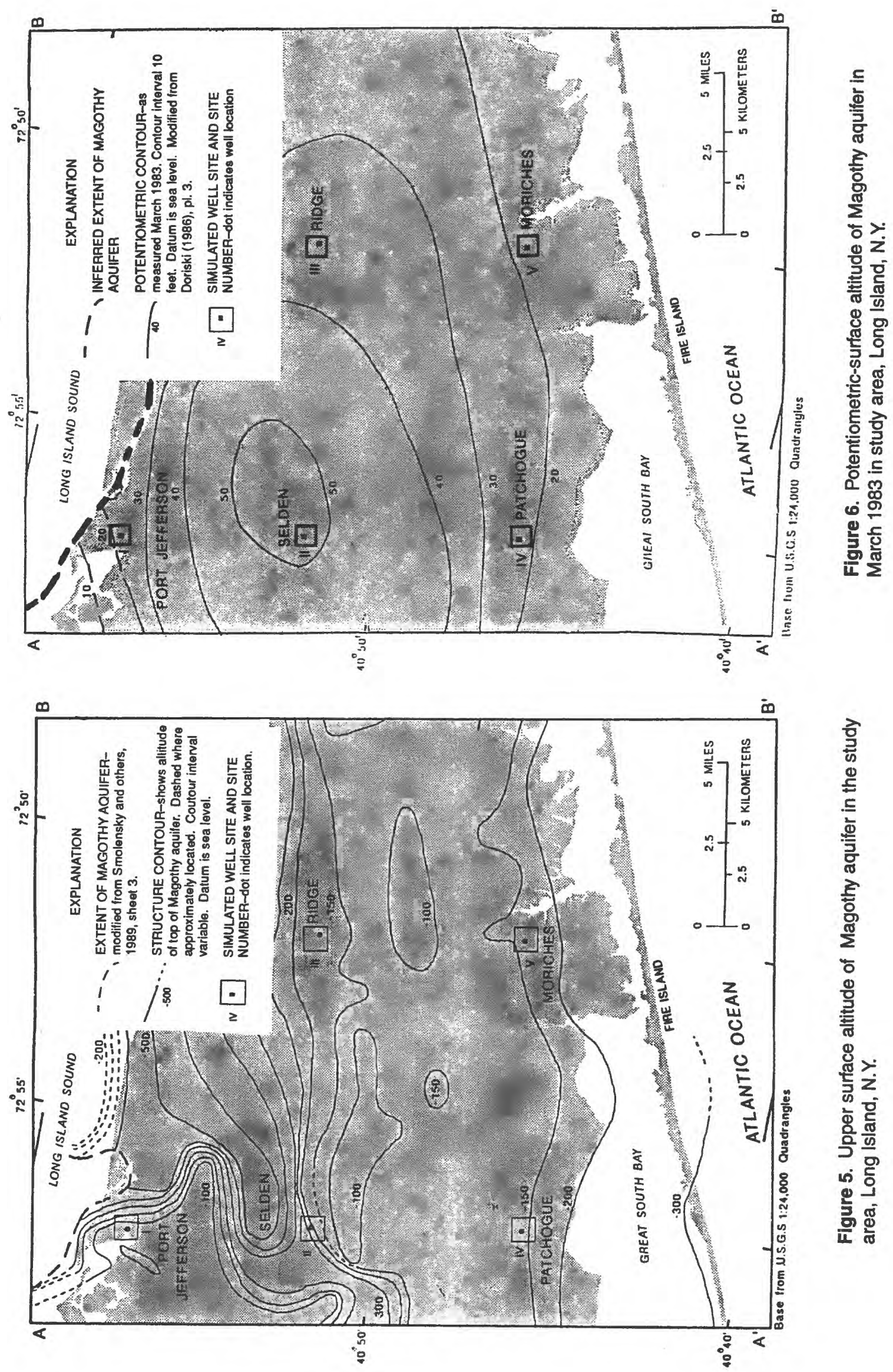

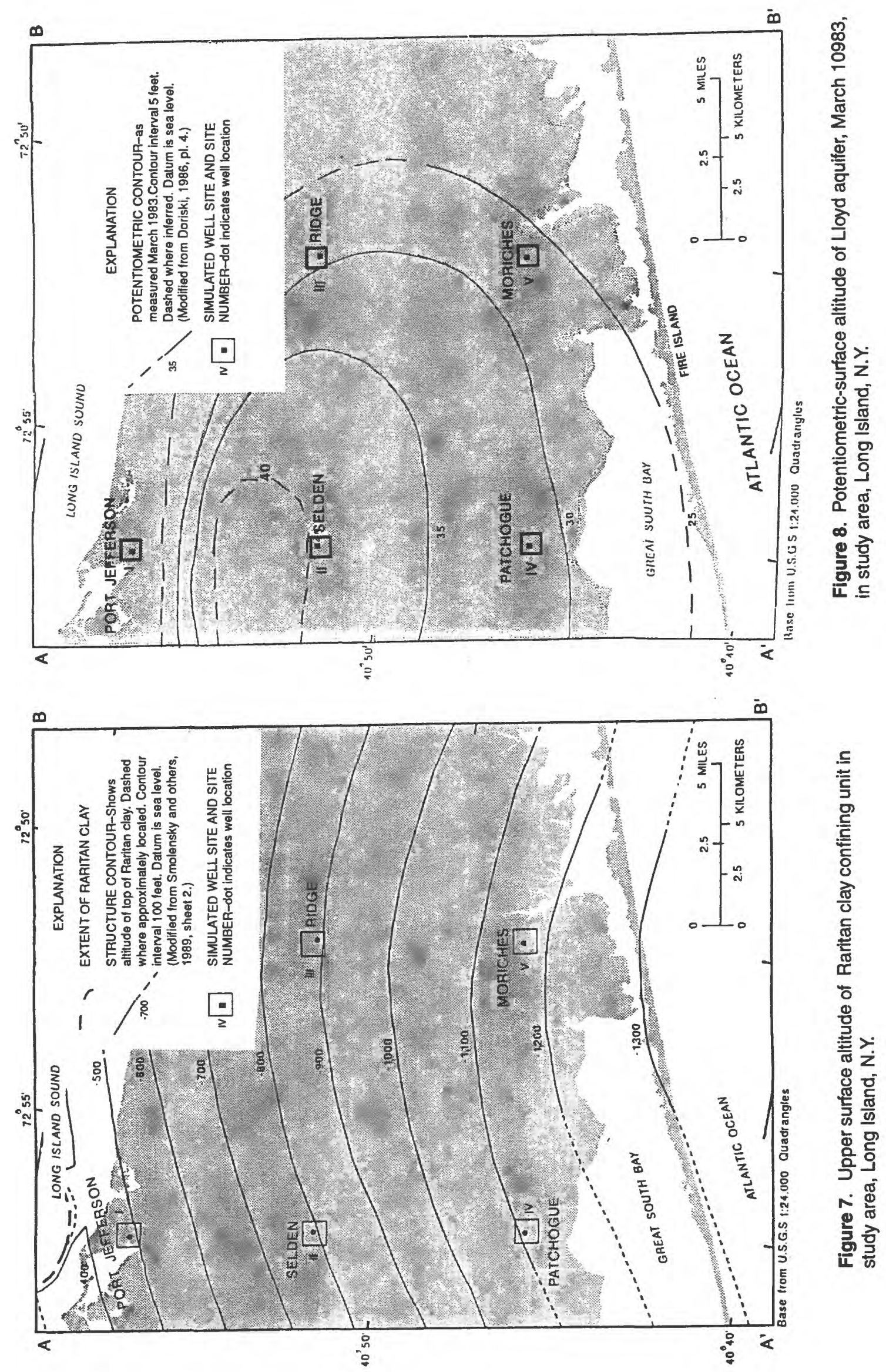


\section{System Boundaries}

Before development, the ground-water system of Long Island was under steady-state conditions, wherein the inflow (recharge) balanced the sum of outflows (discharge), and water levels remained relatively constant (Franke and McClymonds, 1972). Since then, flows at system boundaries and aquifer storage have responded to stresses that result from pumping, sewering, and local recharge by stormwaterdisposal systems. Boundary flows associated with the ground-water system in the study area are depicted in figure 9; ground-water flow rate and direction are affected by proximity to these boundaries. The zone of freshwater on Long Island is separated from the surrounding saltwater by a relatively narrow transition zone, referred to as the saltwater-freshwater interface, the position of which is determined largely by the relative densities and hydraulic heads of the two waters. The increased hydraulic pressure beneath confining layers moves the interface seaward.

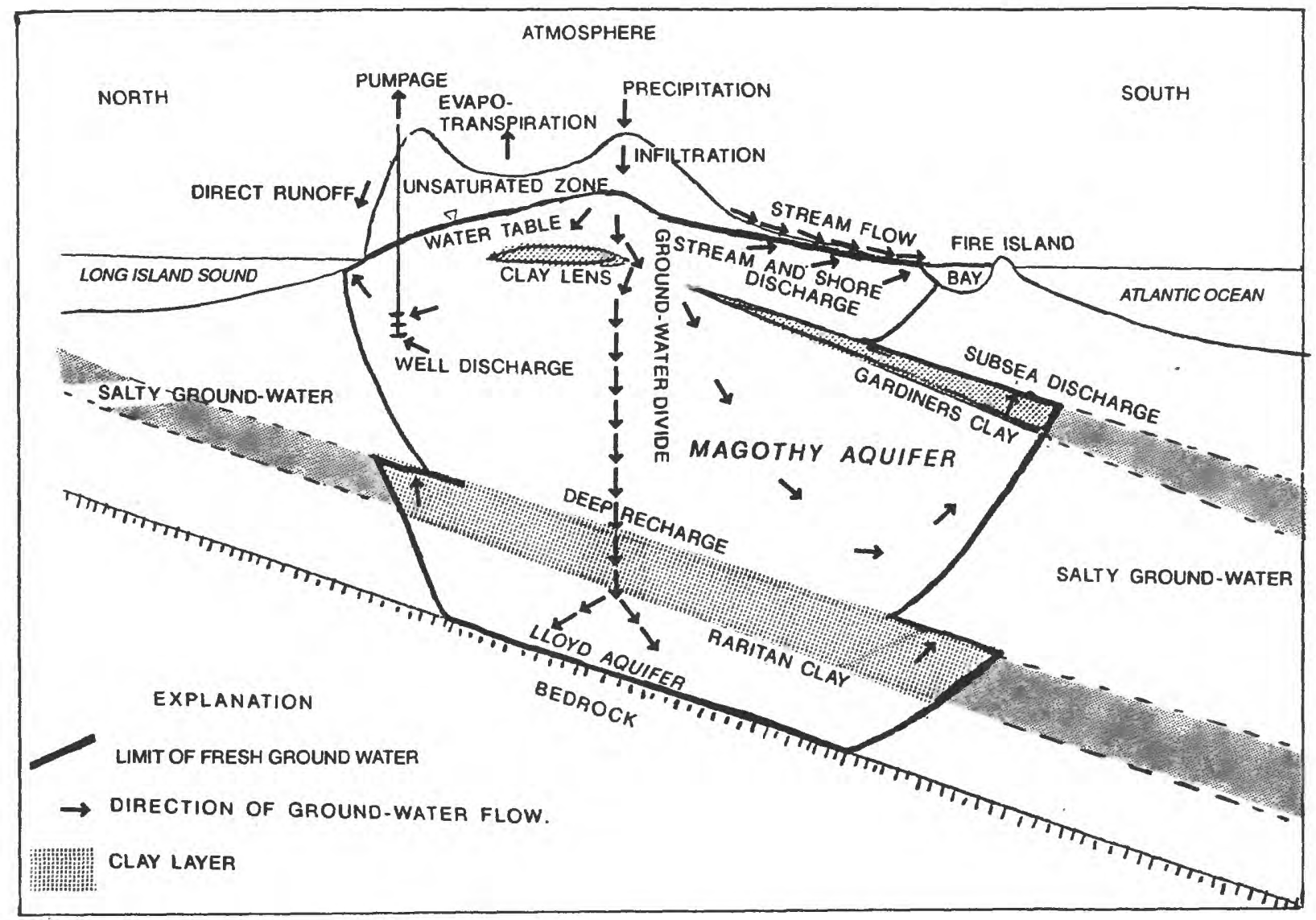

NOT TO SCALE

Figure 9. Generalized north-south hydrogeologic section through study area, Long Island, N.Y., showing ground-water flow boundaries and directions of flow. (Modified from Franke and McClymonds, 1972, fig. 3.) 


\section{Recharge}

Precipitation is the source of all freshwater in central and eastern Long Island. Mean long-term annual precipitation on Long Island is about 44 in., and annual precipitation since 1890 has ranged from 27 to 59 in. (Peterson, 1987). The range of spatial variability is about 5 in. Mean long-term annual evapotranspiration is about 50 percent of precipitation. Mean long-term annual natural recharge, calculated as direct runoff from precipitation minus evapotranspiration, is given in figure 10.

\section{Discharge}

Ground water discharges at land surface by (1) seepage into streams and tidewater bodies, and (2) evapotranspiration. Evapotranspiration occurs in the zone where plant roots intersect the water table; this zone is generally near surface-water bodies. Locations of surface-water bodies and streamflowgaging stations represented in the study-area model are shown in figure 11; the names of streams and bays are listed in table 1 . Subsurface discharge occurs as (1) pumpage, and (2) diffusion into saltwater bodies. The average total public-supply well pumpage for 1984-89 is about 5 million $\mathrm{ft}^{3} / \mathrm{d}$ (New York State Department of Environmental Conservation, written commun., 1990). Of the 140 wells represented in this study, 78 pump from the upper glacial aquifer; the other 62 pump from the Magothy aquifer. Nine of the Magothy wells are on Fire Island.

Table 1. Bays and streams represented by the study-area model, Long Island, N.Y.

[Numbers in parentheses correspond to numbers shown in fig. 11]

\section{BAYS}

Conscience Bay (1)

Port Jefferson Harbor (2)

\begin{tabular}{lll}
\hline STREAMS & & \\
\hline Wading River (3) & Howells Creek (11) & Mud Creek/Old Neck (19) \\
Sans Succi Lakes (4) & Motts Brook (12) & Terrel River (20) \\
Purgatory Creek/Corey Creek (5) & Beaverdam Creek (13) & Little Seatuck Creek (21) \\
Tuthills Creek (6) & Little Neck Run (14) & Seatuck Creek (22) \\
Little Creek (7) & Yapahank Creek (15) & Swan Pond/Cranberry Bogs (23) \\
Mud Creek/Robinson Pond (8) & Lawrence Creek (16) & Sandy Pond (24) \\
Abets Creek (9) & Forge River (17) & Grassy Pond (25) \\
Hedges Creek (10) & Ely Creek (18) & \\
\hline
\end{tabular}



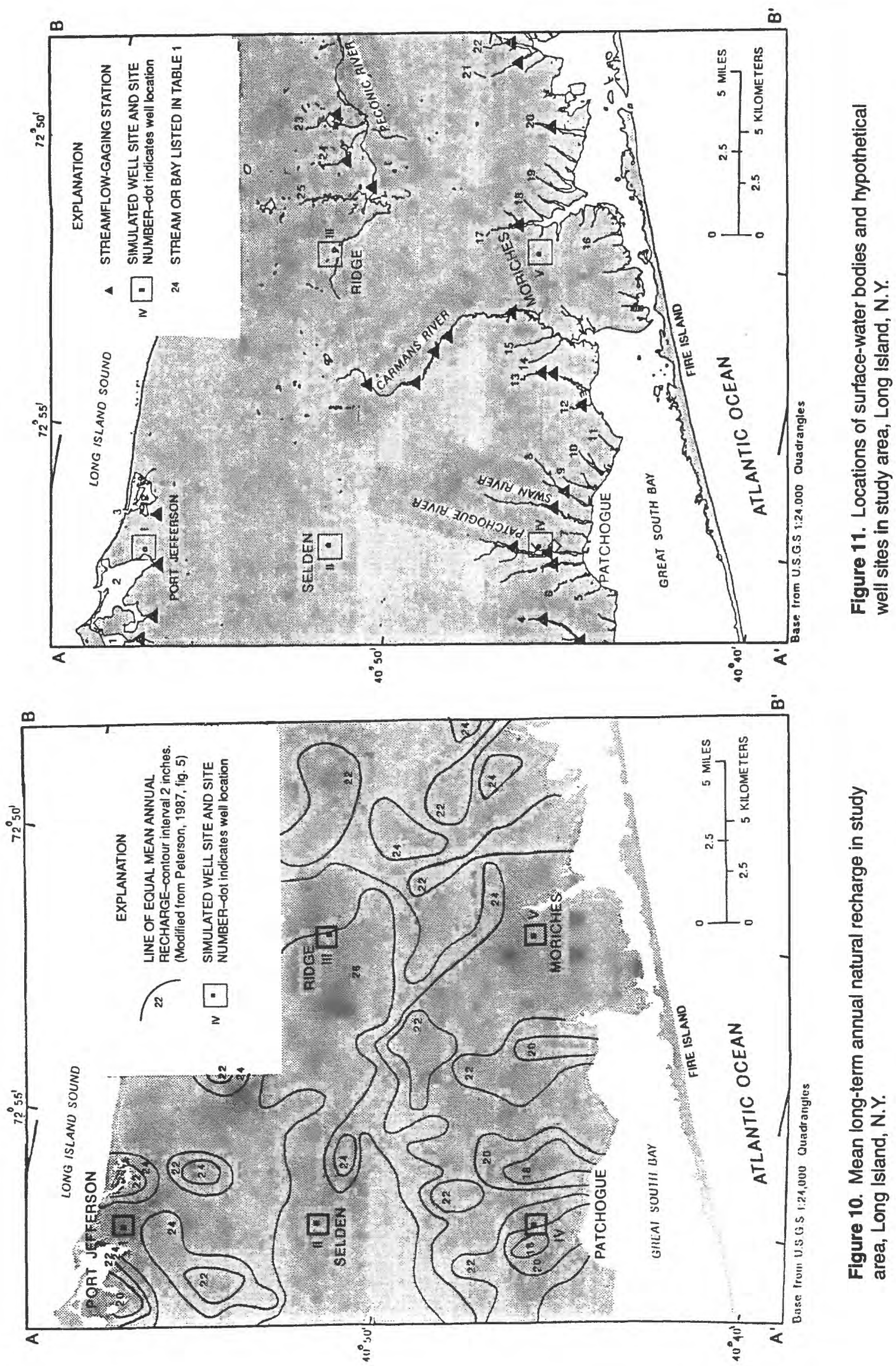


\section{GROUND-WATER-FLOW MODEL}

A four-layer model of regional ground-water-flow on Long Island under general steady-state conditions is described by Buxton and others (1991). In the present study, a seven-layer steady-state ground-water-flow model of the study area was developed with finer discretization than the regional model to allow more detailed representation of the hydrogeologic framework, hydraulic properties, and boundary conditions; the finer discretization also allowed for a more detailed particle-tracking analysis.

The study-area model was calibrated to conditions prevailing in 1983, a period that was representative of long-term average recharge conditions and similar to the steady-state condition simulated in the regional model. Many of the hydraulic characteristics of the regional model were incorporated in the study-area model. The modular finite-difference program (MODFLOW) of McDonald and Harbaugh (1988) was used. The following sections describe the discretization, boundary conditions, and calibration of the study-area model and include a water budget.

\section{Model Discretization and Coupling}

The study-area model has 49,896 cells of varying sizes within a specified area of the regional model that has 3,744 cells of uniform size. All boundaries of the study-area model except the land surface are aligned with cell faces of the regional model. The regional model (fig. 12A) consists of 46 rows and 118

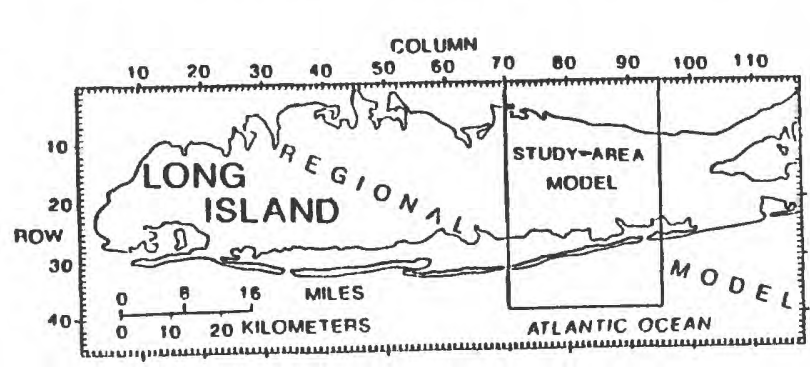

A. Regional model grid

EXPLANATION

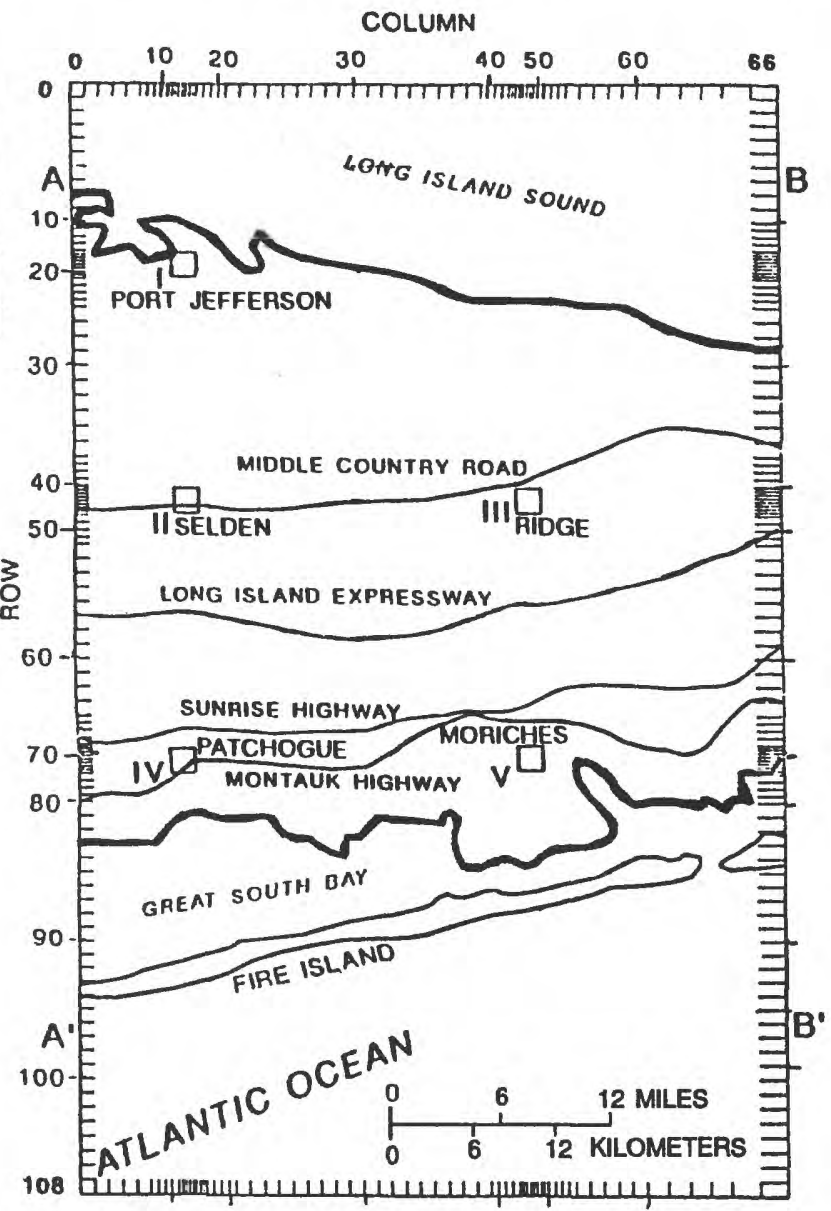

B. Study-area model grid.

Figure 12. (A) Grid of regional Long Island model showing area represented by study-area model.

(B) Grid and principal geographic features of study-area model. 
columns with a uniform grid spacing of $4,000 \mathrm{ft}$; the study-area model (fig. 12B) consists of 66 rows and 108 columns with variable grid spacing ranging from 500 to $5,000 \mathrm{ft}$. Each of the five hypothetical well sites (fig. 12B) consists of 8 rows and 8 columns of 500-by-500-ft cells and is equal to the area of an individual regional model cell $\left(4,000 \mathrm{ft}^{2}\right)$. To simulate subsea discharge from the deep flow system, the study-area model grid is extended beyond the Long Island coast, at land surface, as illustrated in figure 12.

Model geometry was interpolated from the regional model for all units except the upper glacial aquifer. The study-area model represents land-surface topography and the Smithtown clay in greater detail than the regional model. The seven-layer geometry at the eastern and western boundaries of the study area (sections A- $\mathrm{A}^{\prime}$ and $\mathrm{C}-\mathrm{C}^{\prime}$ in fig. 1) is depicted in figure 13.

In the study-area model, layers 1 and 2 represent the upper glacial aquifer. Confining layers and lenses are represented implicitly by the vertical leakance between adjacent layers such that flow between aquifer layers is restricted. (The vertical leakance of a confining layer is defined as its vertical hydraulic conductivity divided by thickness.) The Smithtown clay, in the western part of the area (fig. 3), lies between layers 1 and 2; its thickness and extent are given by Krulikas and Koszalka (1983). The Gardiners Clay and Monmouth greensand are between aquifer layers 2 and 3 (fig. 13). Layers 3 through 6 represent the Magothy aquifer but include some deep sections of the upper glacial aquifer in the northern part of the study area. Layer 7 represents the Lloyd aquifer, which is separated from layer 6 by the Raritan clay confining layer (fig. 13).

\section{Boundary Conditions}

As shown in figures 3,6, and 8, the hydraulic-head gradient along the eastern and western boundaries of the study area runs primarily north and south from the ground-water divide. The small component of flow into or out of these lateral boundaries was estimated from the method of Buxton and Reilly (1987), wherein regional model flows are apportioned and applied as specified fluxes to the finer grid cells of the study-area model. Freshwater-saltwater interfaces along the northern and southern boundaries of the study area model are represented as no-horizontal-flow boundaries, as in the regional model (Buxton and others, 1991). Areas of ground-water discharge to saline surface-water bodies, wetlands, or where freshwater discharges across confining layers and mixes with salty ground water are represented as constant-head boundaries. The position of the freshwater-saltwater interface at lateral boundaries is illustrated in figure 13. Movement of the saltwater interface is of major concern in coastal areas because, if salty water enters the zone of diversion of pumping wells, it can render the freshwater impotable. In the steady-state model, a certain rate of subsea discharge through the top face of active cells overlain by confining layers is maintained to provide a stationary saltwater interface. Neither the locations of, nor the discharges from, central Long Island's subsea interfaces in the study area are measurable and, therefore, must be inferred from system geometry, natural hydrologic conditions, and water-use history. The bottom model boundary, between the Lloyd aquifer and bedrock, is represented as a no-flow boundary.

Recharge on Long Island is not distributed uniformly; rather, it varies locally, depending on precipitation and evapotranspiration. The recharge applied to the study area is equivalent to that in the regional model, as shown in figure 14.

\section{Stream Discharge}

Most streamflow on Long Island consists of ground-water discharge (base flow); the amount derived from storm runoff is negligible, although it could increase if the number of storm sewers that discharge to streams were to increase as a result of future urbanization. The largest streams in the study area (Patchogue, Swan, Peconic, and Carmans Rivers, fig. 15) were simulated by the drain package of MODFLOW (McDonald and Harbaugh, 1988). In this procedure, the streambed altitude is specified as model input. If head in the aquifer is above the altitude of the streambed, ground water discharges to the stream, but if head decreases as a result of pumping from a nearby well, discharge to the stream decreases and will cease when head is drawn down below the streambed altitude. Minor streams were simulated by specified fluxes in 


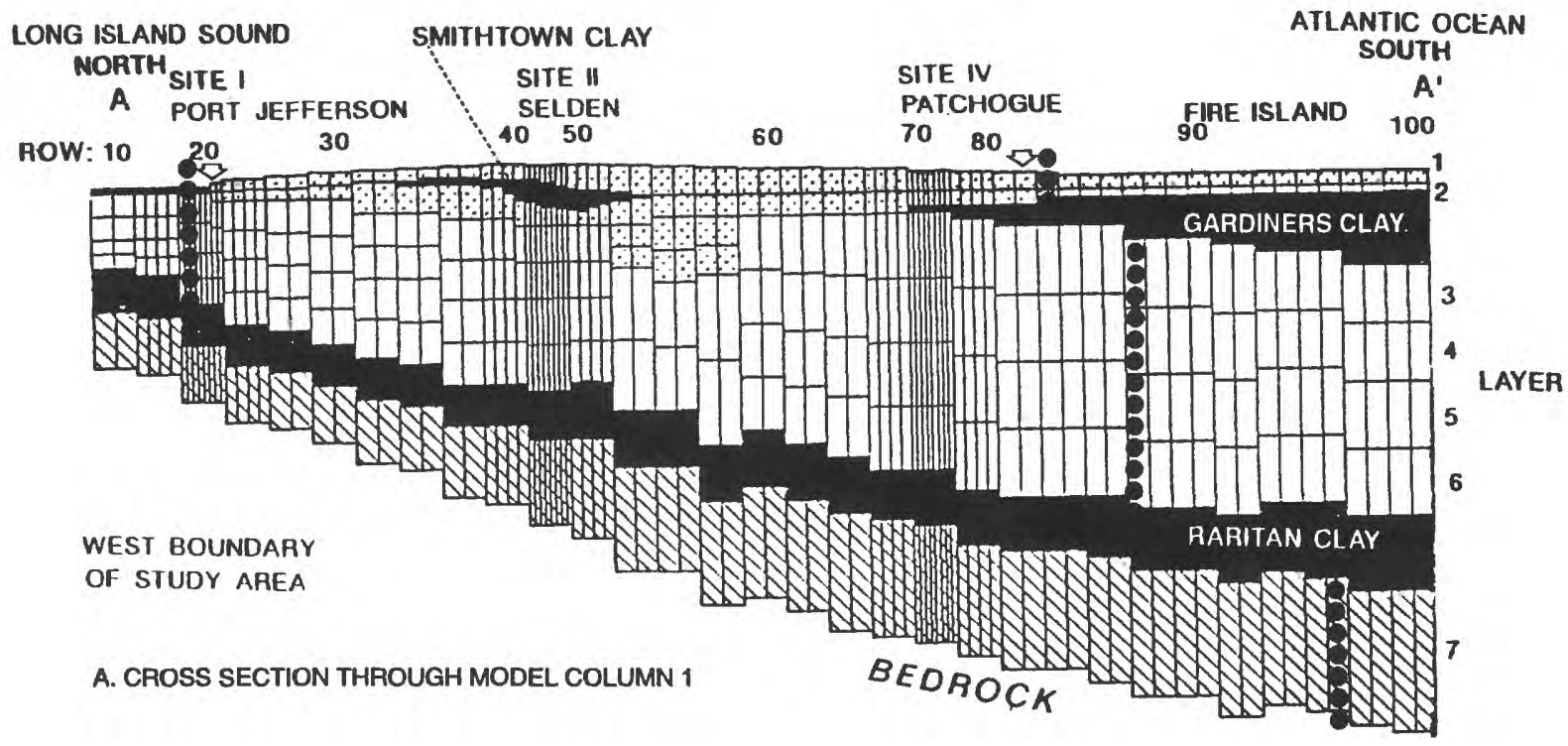

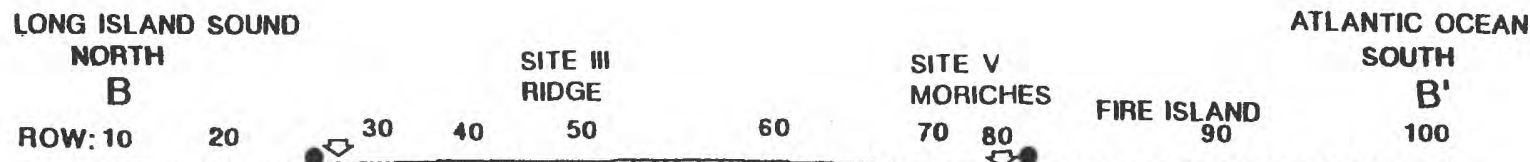

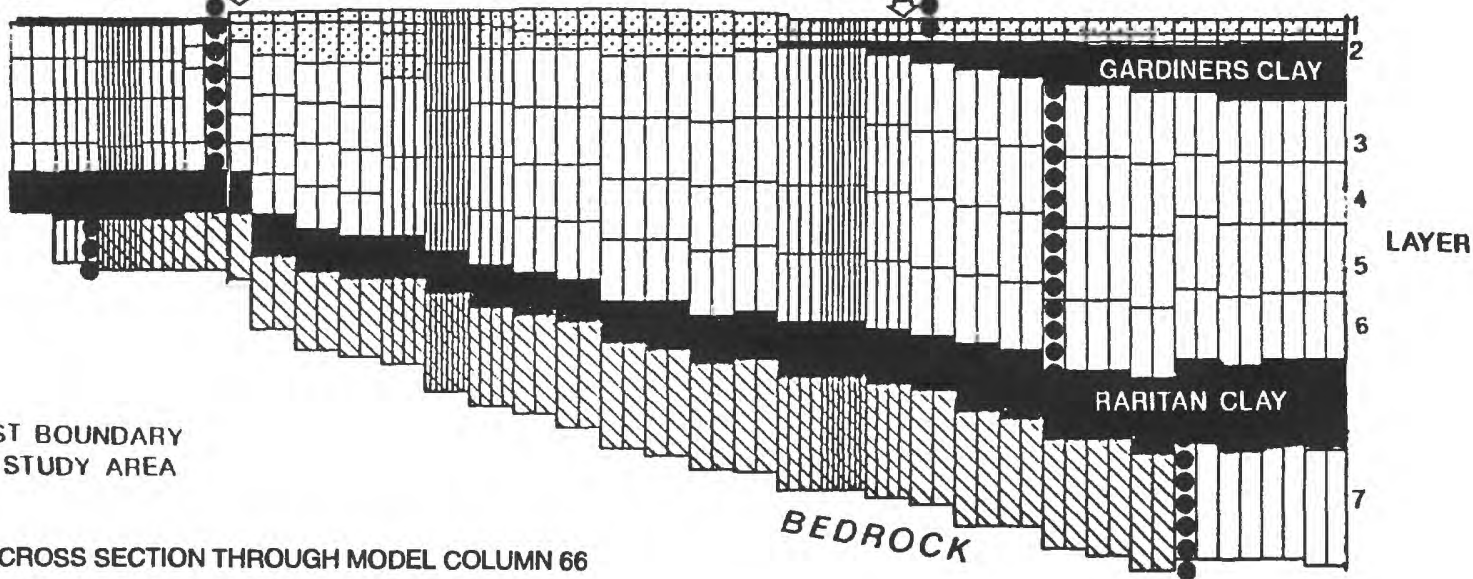

(VERTICAL EXAGGERATION: 25X)

EXPLANATION

$\because$ UPPER GLACIAL AQUIFEH CELL

CONFINING LAYER

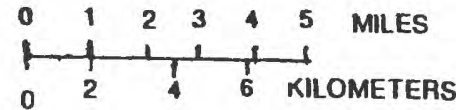

$\square$ MAGOTHY AQUIFER CELL

NV LLOYD AQUIFER CELL

- CONSTANT-HEAD CELL

8 FRESHWATER/SALTWATER INTERFACE

Figure 13. Model layering at western and eastern boundaries of study area, Long Island, N.Y. (Section locations are shown in fig. 1.) 

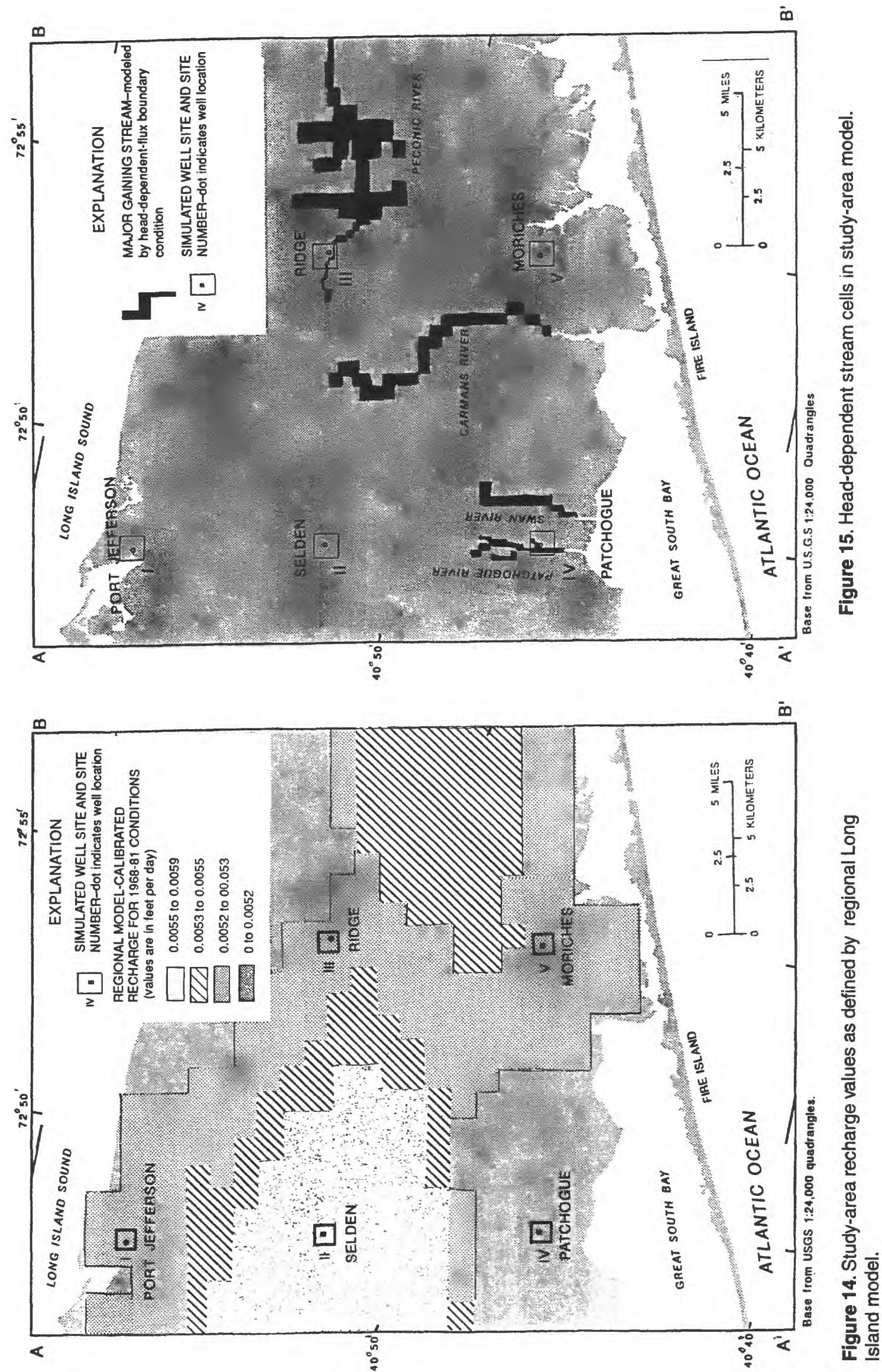
accordance with the regional-model approach. The magnitude and extent of the fluxes along stream reaches were based on stream-discharge measurements that reflect recent flow conditions and surveys of start-offlow locations.

\section{Public-Supply Pumpage}

Discharges from public-supply wells were simulated as the average pumpage for 1984-89, as calculated from data provided by the SCWA. Total pumpage in the study area accounts for about 12 percent of total model discharge. Pumping rates and model-cell locations for each public-supply well are given in table 5 (at end of report).

\section{Model Calibration}

The model was calibrated through a conservative trial-and-error adjustment of hydraulic properties and boundary conditions to fit measured head and flow data. Regional-model values were used in areas of sparse data. The ranges of regional-model hydraulic-conductivity values that were used as initial estimates for calibration of the study-area model are given in table 2 .

Table 2. Range of hydraulic conductivity values used in regional model for each hydrologic unit in study area, Long Island, N.Y.

\begin{tabular}{lcc}
\hline \multicolumn{1}{c}{ Unit } & $\begin{array}{c}\text { Regional model } \\
\text { layer }\end{array}$ & $\begin{array}{c}\text { Hydraulic conductivity } \\
\text { range } \\
\text { (feet per day) }\end{array}$ \\
\hline \hline Upper glacial aquifer & 1 & $48-267$ \\
Upper glacial aquifer (including Smithtown clay) & 1 & $23-48$ \\
Gardiners Clay/Monmouth greensand & $*$ & $0.313 \times 10^{-4}-0.515 \times 10^{-4}$ \\
Magothy aquifer & 2,3 & $35-57$ \\
Raritan clay & $*$ & $0.12 \times 10^{-2}$ \\
Lloyd aquifer & 4 & $35-50$ \\
\hline
\end{tabular}

*Confining units are simulated by vertical conductance between aquifers; value given represents vertical hydraulic conductivity.

The water-table altitude (fig. 3 ) and potentiometric-surface altitudes of the Magothy and Lloyd aquifers in the spring of 1983 (figs. 6 and 8, respectively) were representative of average long-term steady-state levels. The best-fit simulated heads for the upper glacial, Magothy, and Lloyd aquifers are shown in figures 16,17 , and 18 , respectively. Study-area-model geometry is nearly identical to that of the regional model with two exceptions: (1) the study-area model uses a higher hydraulic conductivity value for the upper glacial aquifer in the Smithtown area than the regional model and represents the Smithtown clay as a confining layer with vertical hydraulic conductivity of 0.035 to $0.07 \mathrm{ft} / \mathrm{d}$, and (2) hydraulic conductivity values for the Lloyd aquifer in the study-area model are 15 percent lower than in the regional model.

Simulated streamflows (head-dependent flow to drains) were compared with discharge measurements made at continuous-record and low-flow partial-record stations (Spinello and others, 1984) (fig. 11) and were within 10 percent of the corresponding 1983 measurements at Peconic, Swan, Patchogue, and Carmans Rivers. The sensitivity of simulated stream discharge to hypothetical well pumpage is discussed in a later section. 

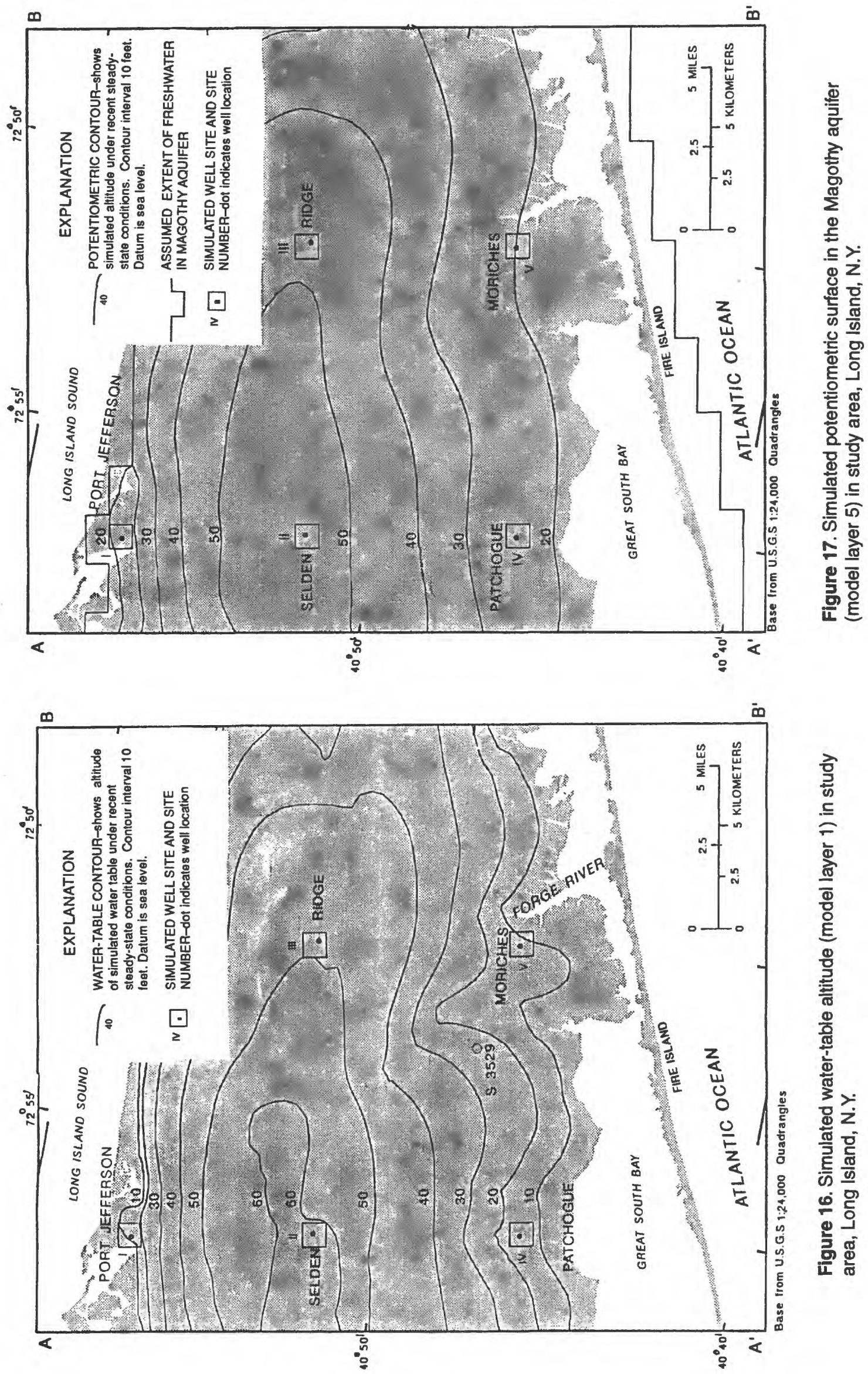


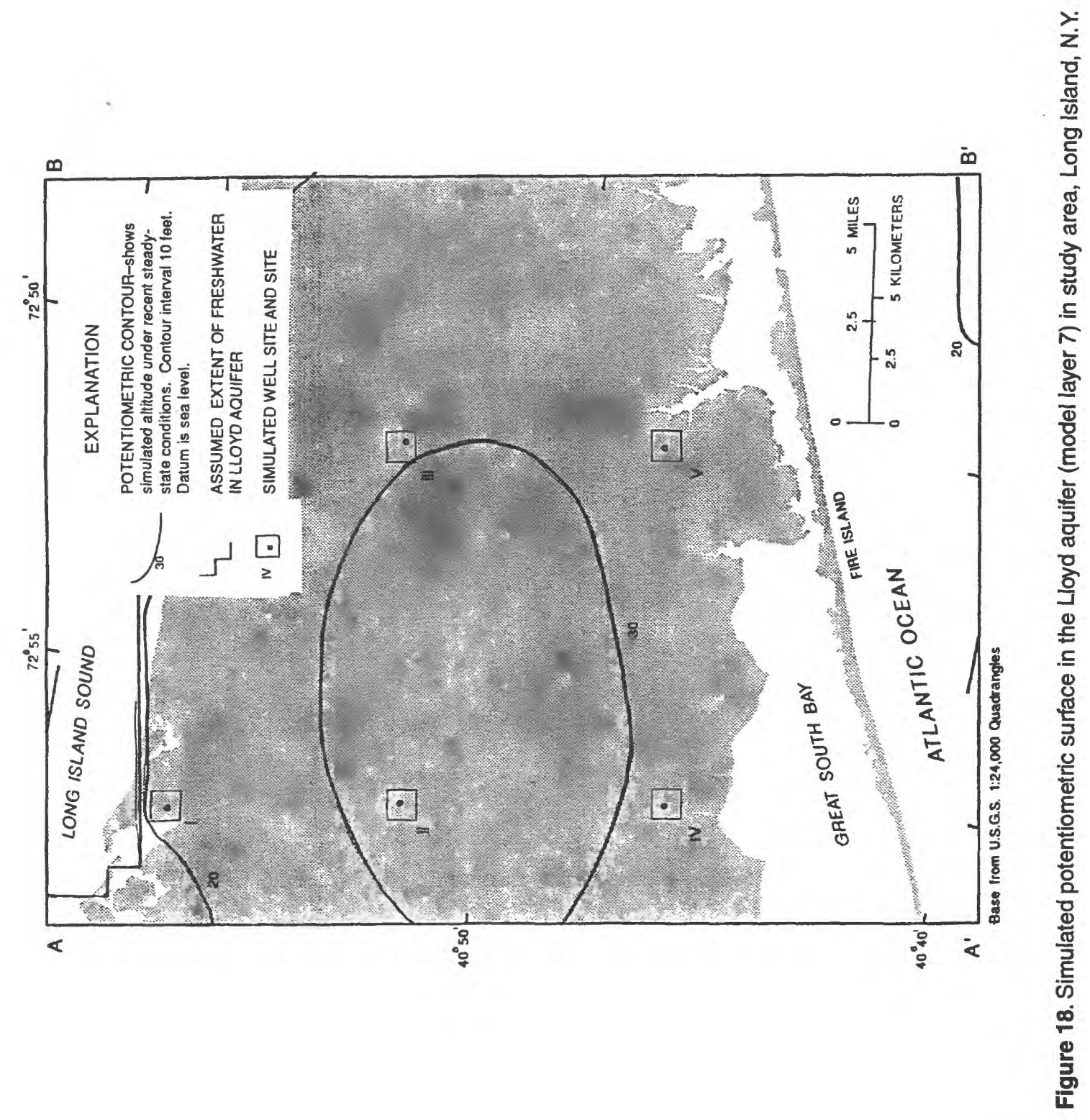




\section{Model Water Budget}

The simulated water budget is presented in table 3. Lateral boundaries, minor streams, water-table recharge, and well pumpage are specified as constant fluxes, and changes in stress can potentially alter these actual fluxes. Hypothetical pumping areas are placed a sufficient distance from lateral boundaries to avoid altering fluxes simulated by the regional model and are not expected to generate conditions that affect the yield of present supply wells. Alteration of the water-table-recharge flux was not considered in this study. Therefore, simulated water-budget adjustments to hypothetical pumpage results from changes in storage and in discharge from the sea floor, the shoreline, and major streams. Local effects of pumping on minor stream discharge are discussed in a later section.

Table 3. Simulated water budget for study area, Long Island, N.Y.

\begin{tabular}{|c|c|c|c|}
\hline Budget component & $\begin{array}{c}\text { Flow rate } \\
\text { (cubic feet per day) }\end{array}$ & $\begin{array}{l}\text { Direction } \\
\text { of flow }\end{array}$ & $\begin{array}{l}\text { Percentage of total } \\
\text { inflow or outflow }\end{array}$ \\
\hline \multicolumn{4}{|c|}{ Boundary flows (by regional model layer) } \\
\hline \multicolumn{4}{|l|}{ East face } \\
\hline Layer 1 & 365,418 & Inflow & 0.8 \\
\hline Layer 2 & 370,816 & Outflow & .9 \\
\hline Layer 3 & 577,925 . & Outflow & 1.3 \\
\hline Layer 4 & 181,206 & Outflow & .4 \\
\hline \multicolumn{4}{|l|}{ West face } \\
\hline Layer 1 & 179,700 & Outflow & .4 \\
\hline Layer 2 & 71,881 & Inflow & .2 \\
\hline Layer 3 & 159,790 & Inflow & .4 \\
\hline Layer 4 & 136,431 & Inflow & .3 \\
\hline Recharge from precipitation & $42,709,000$ & Inflow & 98.3 \\
\hline Pumpage & $-5,162,078$ & Outflow & 11.9 \\
\hline \multicolumn{4}{|l|}{ Streams } \\
\hline Constant-flux cells & $-4,508,395$ & Outflow & 10.4 \\
\hline Head-dependent cells & $-9,706,400$ & Outflow & 22.3 \\
\hline Shoreline and subsea outflow & $-22,756,000$ & Outflow & 52.4 \\
\hline
\end{tabular}




\section{PARTICLE-TRACKING TECHNIQUE}

The particle-tracking technique generates ground-water pathlines and traveltime from a numerical flow simulation and can be incorporated into solute-transport models to account for the advective component of transport (Pollock, 1989). Application of particle-tracking simulation requires specification of intercell volumetric flow rates for the horizontal, vertical, and depth planes $-\mathrm{Q}_{\mathrm{x}}, \mathrm{Q}_{\mathrm{y}}$, and $\mathrm{Q}_{\mathrm{z}}$-as calculated by MODFLOW. The face-flow terms and their coordinate system are illustrated in figure 19.

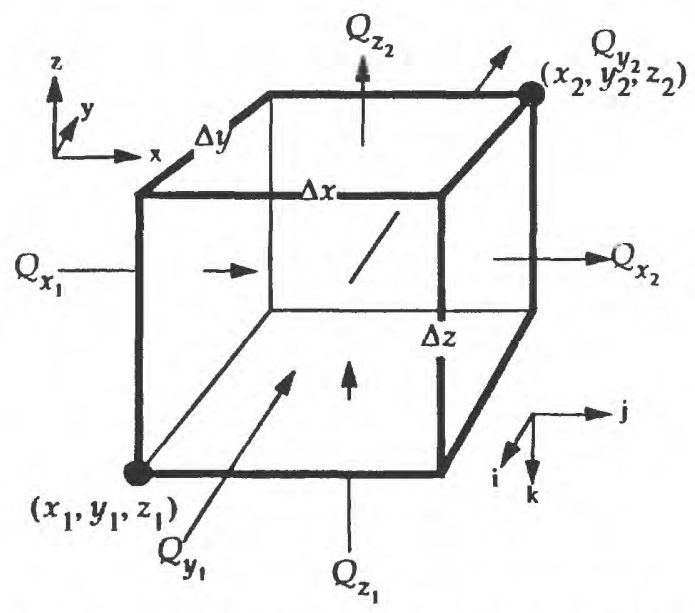

Figure 19. Coordinate system and flow at faces of a MODFLOW finite-difference cell. (From Pollock, 1989, fig. 1.)

The ground-water velocity vector components at point $x_{p}, y_{p}, z_{p}$, denoted by $V_{x_{p}}, V_{y_{p}}$, and $V_{z_{p}}$, depend on the hydraulic characteristics of the model cell, including porosity (n) and cell-face areas ( $\Delta \mathrm{x}, \Delta \mathrm{y}$, and $\Delta \mathrm{z})$.

Model porosity values of 30 percent were assigned to the upper glacial and Magothy aquifers, and values of 25 percent were assigned to confining layers and the Lloyd aquifer. The finite-difference approximation of the $\mathrm{x}$-component of velocity at point $\mathrm{p}$ is obtained by linear interpolation of the flow velocities at the cell faces, that is:

$$
\frac{\left(V_{x_{2}}-V_{x_{1}}\right)\left(x_{p}-x_{1}\right)}{\Delta x}+V_{x_{1}}
$$

where $\mathrm{V}_{\mathrm{x}_{1}}=\mathrm{Q}_{\mathrm{x}_{1}} / \mathrm{n}(\Delta \mathrm{x} \Delta \mathrm{z})$, and $\mathrm{V}_{\mathrm{x}_{2}}=\mathrm{Q}_{\mathrm{x}_{2}} / \mathrm{n}(\Delta \mathrm{x} \Delta \mathrm{z})$. The $\mathrm{y}$ and $\mathrm{z}$ components are treated similarly (Pollock, 1989). The movement of particles in three dimensions can be tracked forward or backward along their pathlines.

Movement of a particle through the velocity-vector field from its position at time $t, x_{p}\left(t_{1}\right)$, over a time interval $\Delta t$, to its position at time $t_{2}, x_{p}\left(t_{2}\right)$, requires time-coordinate locations. At time $t_{2}=t_{1}+\Delta t$, the particle is moved to $\mathrm{x}_{\mathrm{p}}\left(\mathrm{t}_{2}\right)$, by adding the change in particle location to the initial location $\mathrm{x}_{1}$, that is:

$$
\mathrm{x}_{\mathrm{p}}\left(\mathrm{t}_{2}\right)=\mathrm{x}_{\mathrm{p}}\left(\mathrm{t}_{1}\right)+\Delta \mathrm{x}_{\mathrm{p}}
$$

The change in the particle $\mathrm{x}$-component location is

$$
\Delta \mathrm{x}_{\mathrm{p}}=1 / \mathrm{A}_{\mathrm{x}}\left[\mathrm{V}_{\mathrm{x}_{\mathrm{p}}}\left(\mathrm{t}_{1}\right) \exp \left(\mathrm{A}_{\mathrm{x}} \Delta \mathrm{t}-\mathrm{V}_{\mathrm{x}_{1}}\right)\right],
$$

where $A_{x}=\left(V_{x_{2}}-V_{x_{1}}\right) / \Delta x$ is the gradient of the $x$-component velocity across the cell, and $V_{x_{p}}\left(t_{1}\right)$ is the time rate of change of the $\mathrm{x}$ location of the particle at $t_{1}$; similar equations apply for the $\mathrm{y}$ and $\mathrm{z}$ coordinates. 
The sections that follow include a series of diagrams that depict pathlines in three dimensions; the orientation of these diagrams is depicted in figure 20. Particle-tracking graphics generated by MODPATH are transformed into horizontal layers of constant thickness through a normalizing/averaging procedure, described in Pollock (1989), that is unlike the vertical section in figure 13, in which the grid is deformed in the vertical direction to allow cells to conform to stratigraphic units that are not horizontal and that vary in thickness. Confining layers, represented as spaces between aquifer layers, are similarly transformed.

A. Horizontal face.

B. Vertical face.
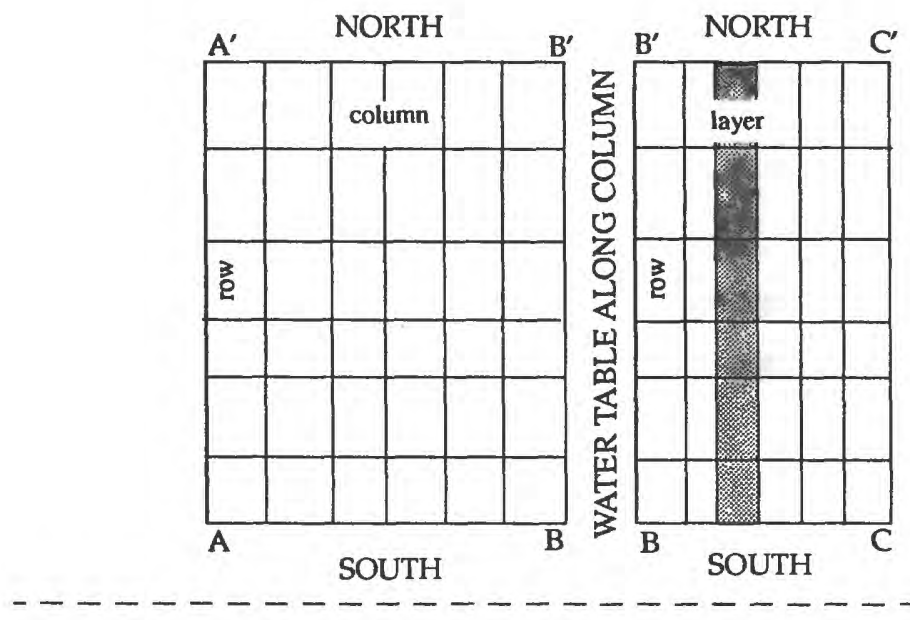

SOUTH

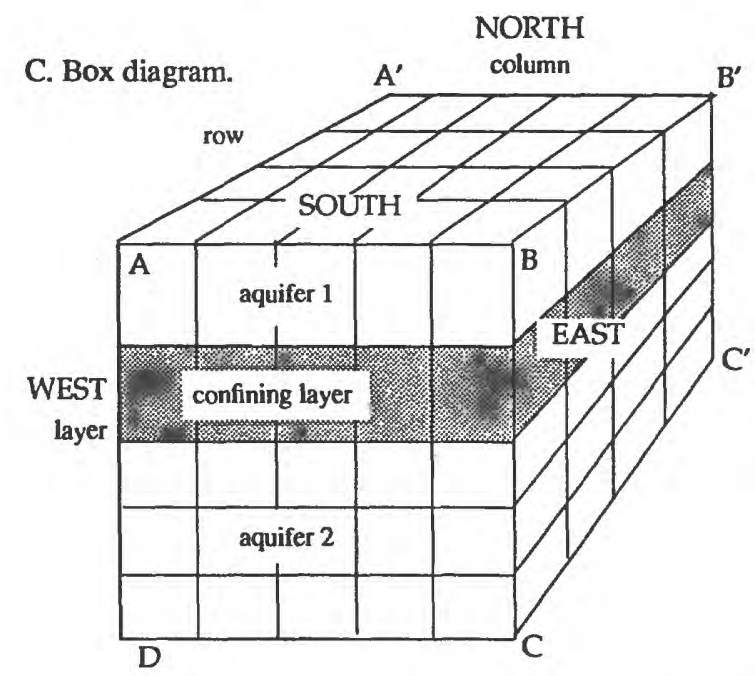

Figure 20. Study-area model grid showing orientation of rows, columns, and layers as rendered in figures $22,25,26,28,29$, and 30 .

\section{Delineation of Regional Flow Regime}

The particle-tracking technique has been applied to the regional model to delineate recharge areas to the Magothy and Lloyd aquifers (Buxton and others, 1991). In this procedure, an array of 16 particles is placed at the water-table surface of each model block, and the paths of these particles are tracked through MODPATH. The starting locations of particles that enter the Magothy and Lloyd aquifers are identified and 
represent recharge areas under simulated predevelopment conditions; these areas are shown in figure 21. Recharge that does not enter the Magothy aquifer flows only within the upper glacial aquifer and discharges directly to shallow boundaries.

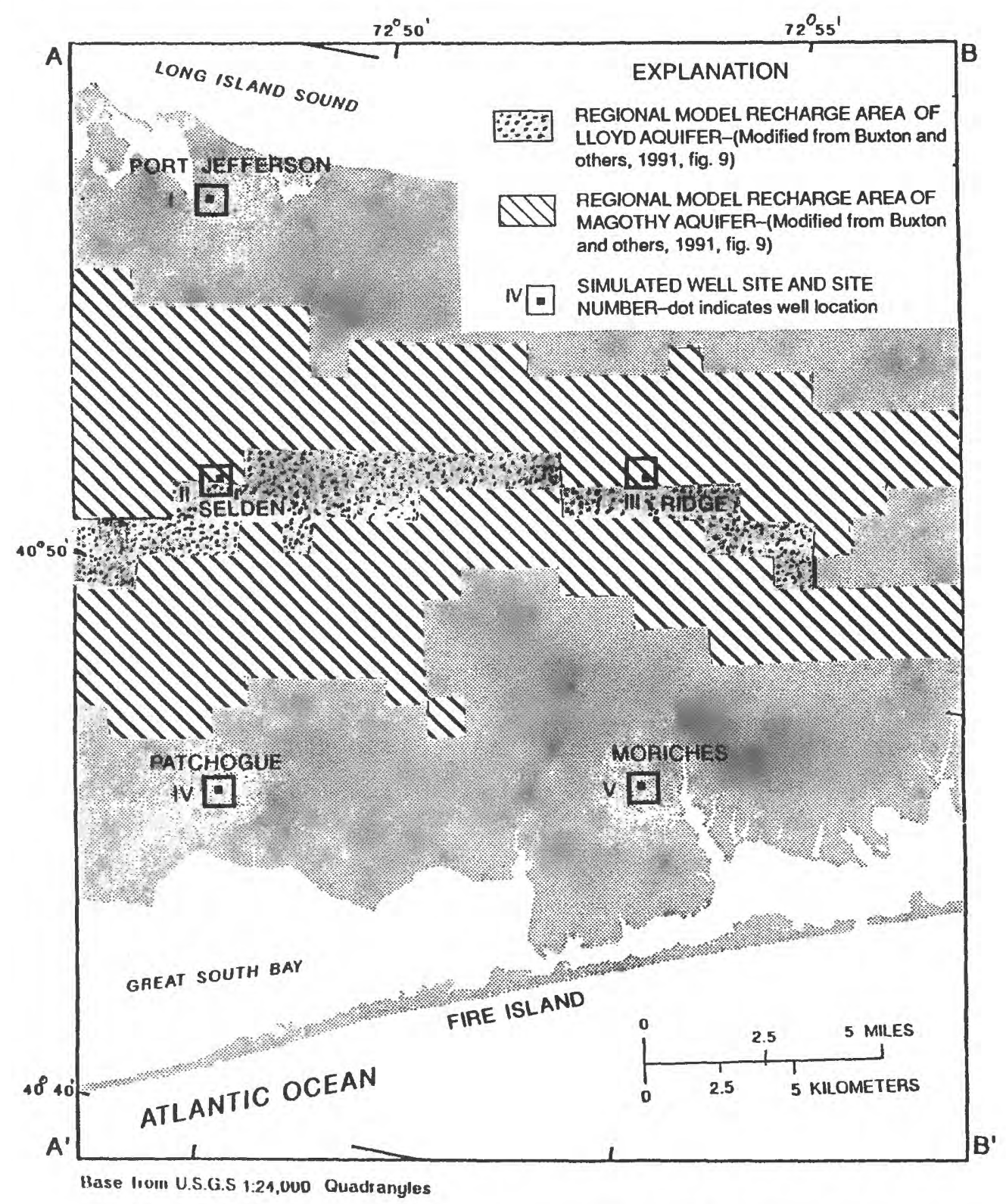

Figure 21. Recharge areas of the Magothy and Lloyd aquifers in the study area, as generated by regional Long Island model.

Particle pathlines simulated by the study-area model and projected along a north-south section through each of the five hypothetical well sites are shown in figure $22 \mathrm{~A}$ (column 14, for sites I, III, IV) and 22B (column 47, for sites II and V). Particles are started at the water table of all cells along the two columns and tracked forward to discharge points (as fluxes out of lateral study-area boundaries or to wells, streams, wetlands, or salty ground water through confining layers). Residence times range from less than 1 year for particles near a discharge boundary in the upper glacial aquifer, to several thousand years for particles traveling deep into the system beneath Fire Island. 


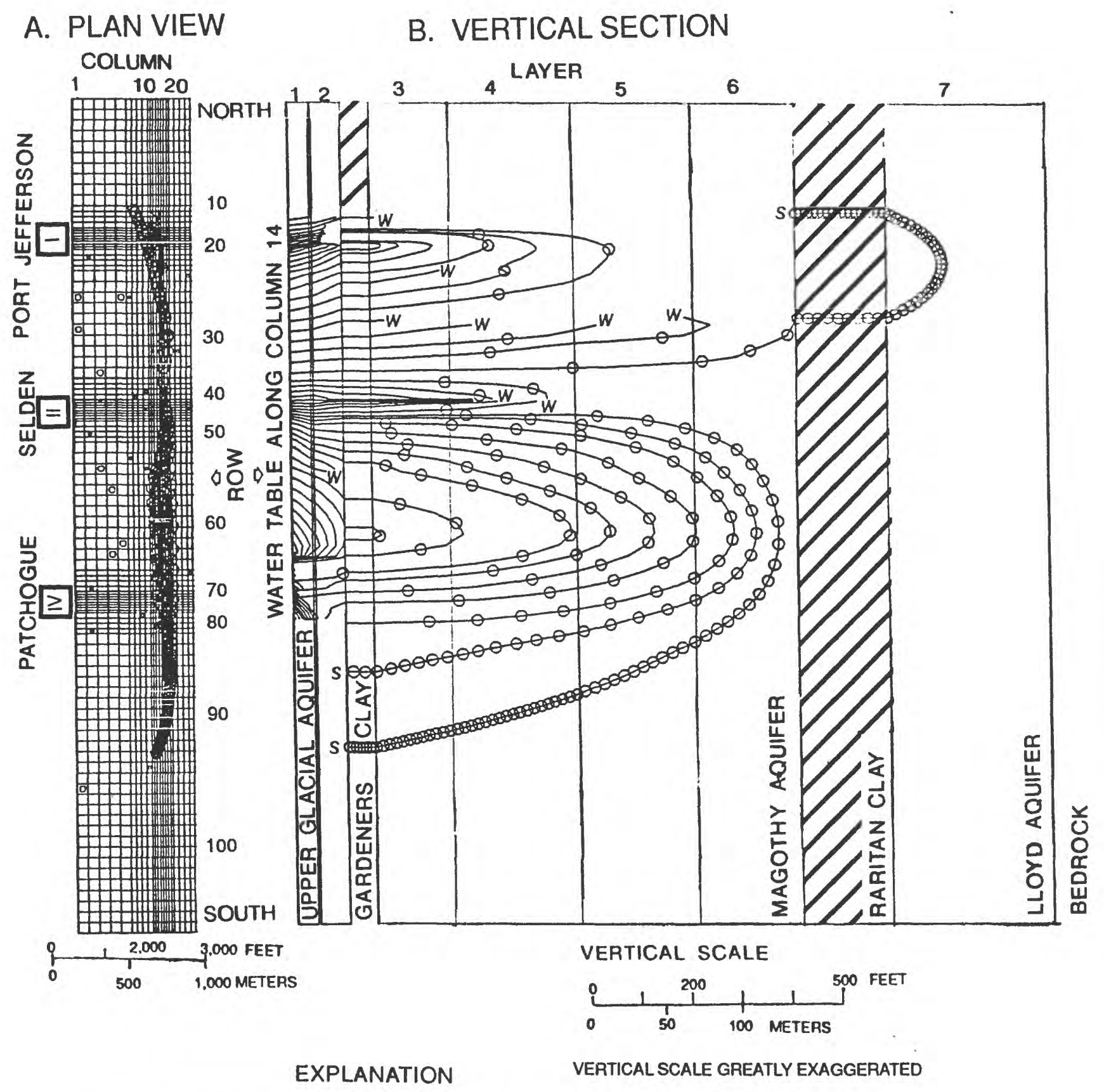

W-o PARTICLE PATHLINE-forward tracked from water table to discharge at W (public-supply well in Magothy aquifer) or S (upward through confining layer into salty ground water). Circles denote 50-year traveltime.

回 MODEL CELL WITH SIMULATED PUBLIC-SUPPLY WELL

II SIMULATED WELL SITE AND SITE NUMBER

Figure 22A. Particle-tracking analysis of ground-water flowpaths along study-area model column 14, Long Island, N.Y. (Orientation is depicted in fig. 20.) 
A. PLAN VIEW

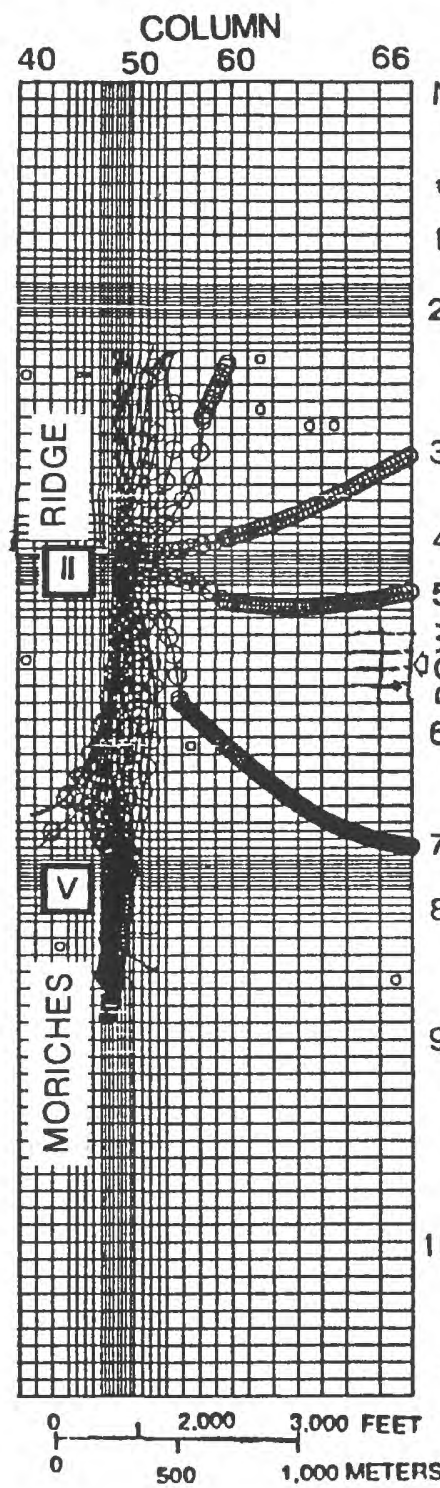

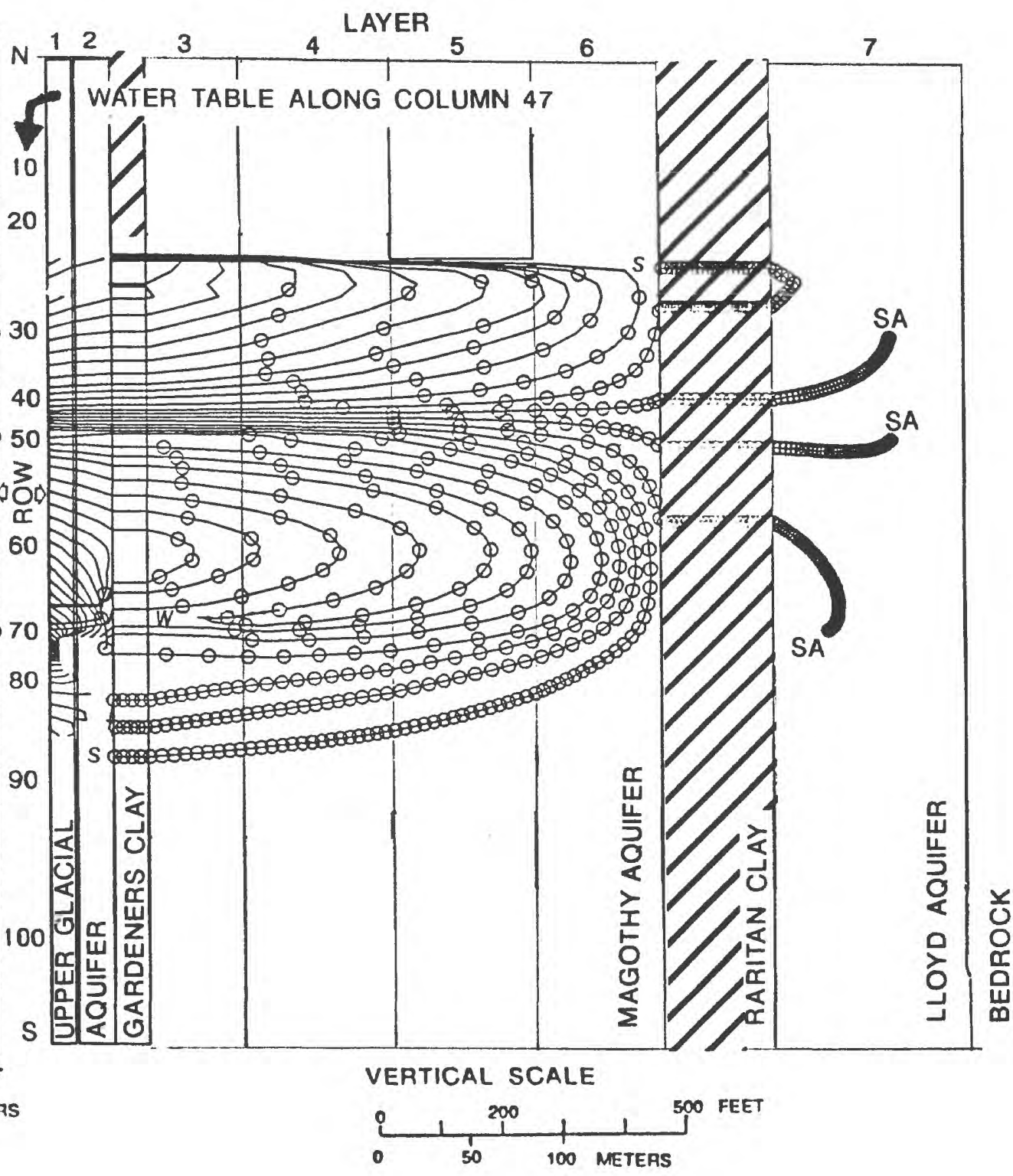

EXPLANATION

VERTICAL SCALE GREATLY EXAGGERATED

W-a PARTICLE PATHLINE-forward tracked from water table to discharge at W (public-supply well in Magothy aquiler) or S (upward through confining layer into salty ground water). Circles denote 50-year traveltime.

을 MODEL CELL WITH SIMULATED PUBLIC-SUPPLY WELL

III SIMULATED WELL SITE AND SITE NUMBER

Figure 22B. Particle-tracking analysis of ground-water flowpaths along study-area model column 47, Long Island, N.Y. (Orientation is depicted in fig. 20.) 


\section{Factors that Affect Contributing Areas}

The boundaries of the three-dimensional conduit through which water flows toward the well define the zone of diversion, and the corresponding land surface is the contributing area (fig. 23). The contributing area to a pumping well can be delineated through backward particle tracking of individual pathlines, or groups of pathlines, that discharge to the well screen. Pathlines represent the movement of water entering the aquifer system as recharge at the water table; therefore, tracking particles backward from the well to their point of entry at the water table results in a map of the contributing area. In the presence of a regional flow gradient, the zone of diversion becomes elliptical about the well, and water beyond this ellipse is not captured. An idealized zone of diversion (in vertical section) is aligned with the corresponding contributing area (in plan view) in figure 23. A cone of depression forms in the vicinity of the well, where head is decreased by pumping. The contributing area extends upgradient to the ground-water divide (Morrissey, 1987).

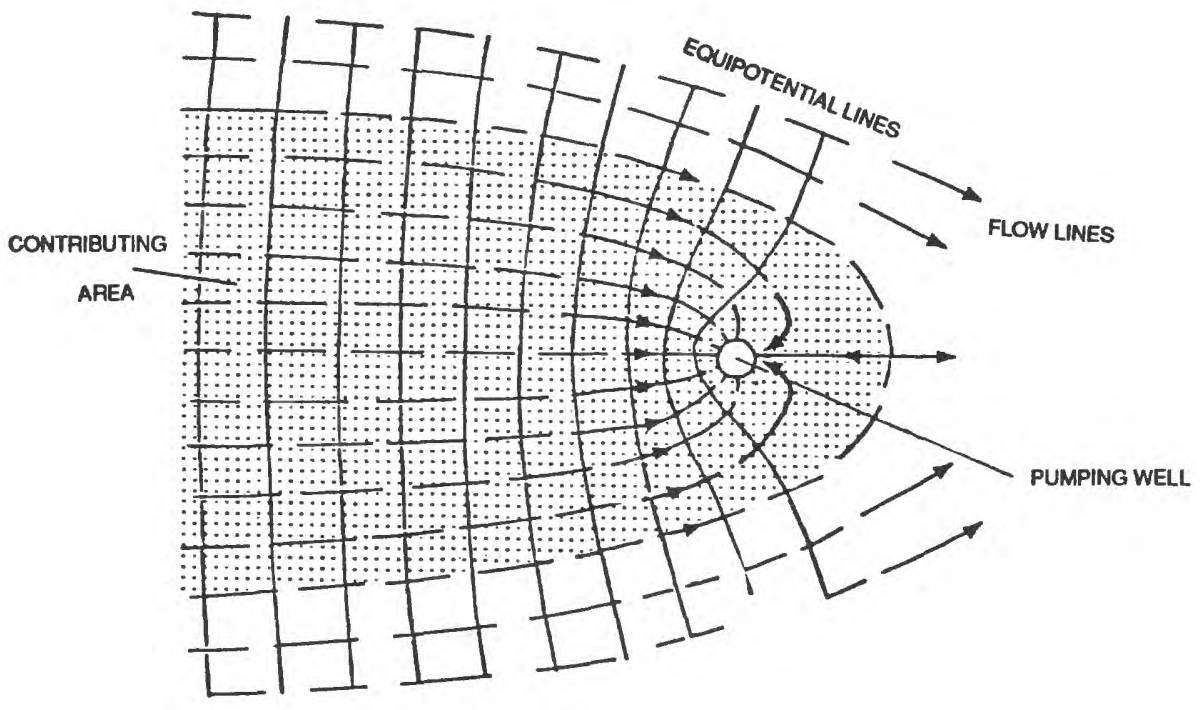

A. PLAN VIEW SHOWING CONTRIBUTING AREA AT LAND SURFACE

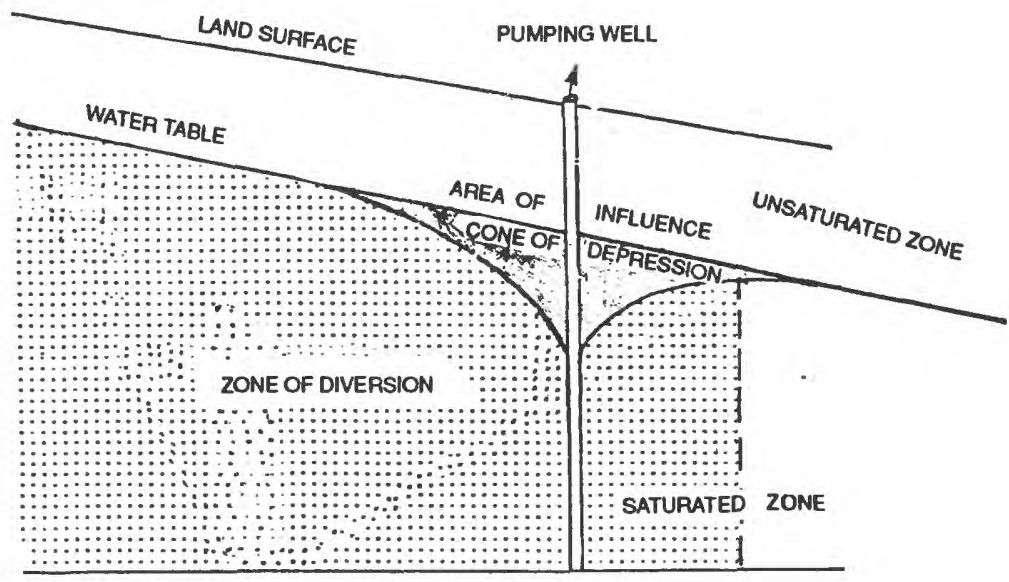

B. VERTICAL SECTION ALONG CENTERAXIS OF PLAN VIEW SHOWING ZONE OF DIVERSION IN SATURATED ZONE

Figure 23. Zone of diversion and contributing area around a pumping well: A. In plan view. B. In vertical section. (Modified from Morrissey, 1987, fig. 7.) 
The accuracy of a simulated contributing area depends on the accuracy of the ground-water-flow model, and any factor that affects ground-water flow patterns can affect the shape of the contributing area. The degree of model discretization can affect particle pathways through "weak sinks" (cells from which only part of the inflow discharges to a sink such as a well; the rest discharges to other points). In particle tracking, the contributing area to an internal-boundary sink, such as a pumped well, gaining stream, or drain consists of the area containing particles that enter the flow system and that discharge to that sink. If weak sinks are present, contributing-area delineations based on coarse model discretization cannot determine whether or not a particle entering a weak sink should discharge to the sink (Pollock, 1989). Sufficiently fine model discretization causes weak sinks to become strong sinks (cells in which all inflow discharges to the sink), as illustrated in figure 24 . In the analysis that follows, the model-grid spacing of $500 \mathrm{ft}$ in the vicinity of the hypothetical well sites is small enough that hypothetical wells are strong sinks, and the effect of weak sinks is minimal. In other parts of the model, however, where grid spacing is larger, the effect of weak sinks can be more pronounced.

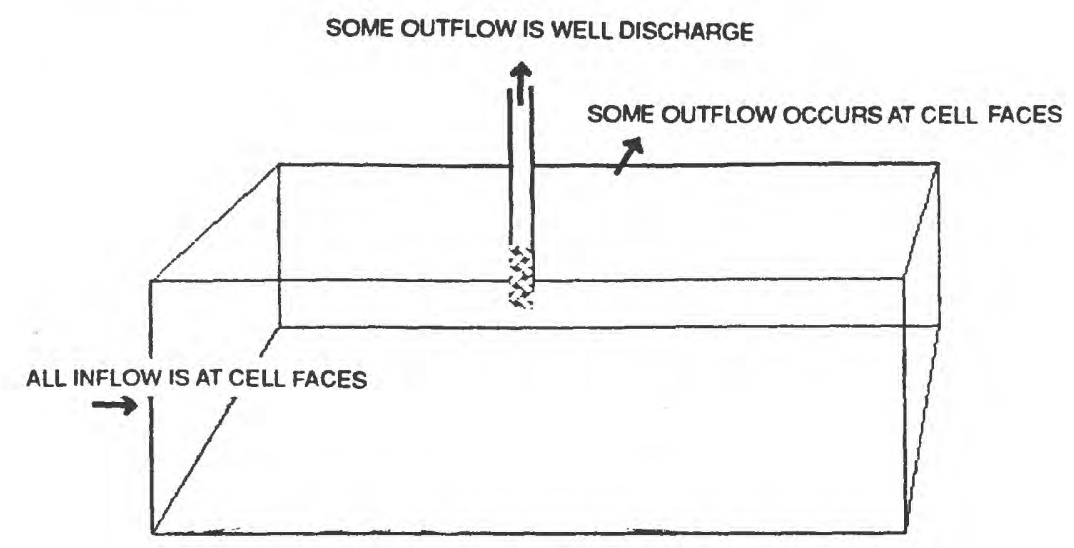

A. SINGLE CELL WITH WEAK-SINK CONDITION: Outflow-particle position is Indeterminate

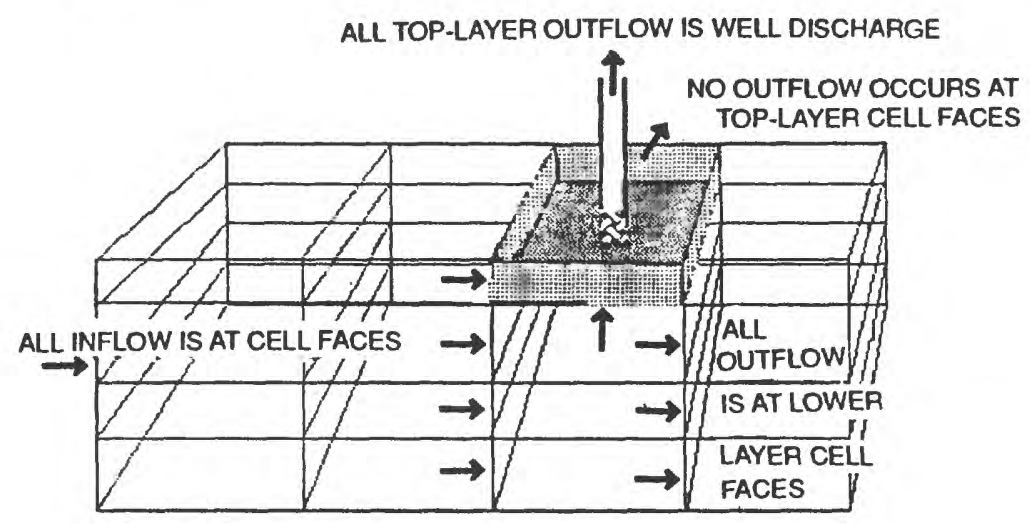

B. MULTIPLE CELLS ELIMINATE WEAK-SINK CONDITION: outflow-particle position is specific

\section{EXPLANATION}

WELL SCREEN

BOTTOM FACE OF TOP-LAYER CELL-strong sink

$\rightarrow$ DIRECTION OF FLOW

Figure 24. Particle flow: A. In a single model cell specified as a weak sink. B. in finely discretized cells that include a strong sink. 


\section{Pumping Rates}

Pumping rate has a direct effect on the shape and size of contributing areas because recharge to the contributing area balances the amount of water discharged from the well. The size of the area $A$ from which recharge is supplied under uniform, steady-state conditions of water-table recharge at a rate $R$ is described by

$$
A=Q / R
$$

where $\mathrm{A}=$ size of contributing area $\left(\mathrm{L}^{2}\right)$, and

$Q=$ rate of discharge to well $\left(\mathrm{L}^{3} / \mathrm{T}\right)$.

\section{Confining Layers}

When a well is pumped, the pressure decrease in the aquifer can be propagated unevenly through the system as a result of refraction by layers of low permeability. A well screened beneath a confining layer, for example, will produce a larger cone of depression than a well pumping at an equal rate from a similar depth in an unconfined unit because confined aquifers have less storage capacity-specific yield of unconfined aquifers is about 1,000 times larger than the storage coefficient of confined aquifers.

\section{Proximity of Well to Flow Boundaries}

The size and shape of a well's contributing area also depends, in part, on proximity of the well to sources of induced recharge and to discharge boundaries. Losses of water through pumping are balanced by decreased outflow to discharge boundaries and (or) increased inflow at recharge boundaries. An example of change in outflow to a nearby flow boundary is when a pumping well causes the water table to decline below the stage of a nearby stream - the decreased discharge of ground water to the stream will result in diminished streamflow, and, if the water table declines below the streambed altitude, the gradient between stream and aquifer will reverse, causing water from the stream to move into the aquifer and toward the well. Similarly, a wetland can go dry if drawdown in the vicinity causes the water table to decline below the root zone.

\section{Delineation of Contributing Areas to Hypothetical Wells}

Particle-tracking analyses were completed for each of the five hypothetical well sites to delineate contributing areas to the pumping wells under a variety of hydrologic settings. Results are presented for (1) wells screened in homogeneous zones of diversion such that water flows directly to the well through aquifers without traversing confining units, and (2) wells screened in heterogeneous zones such that water must flow through confining units to be captured. Particle-tracking analyses of wells screened in homogeneous zones include wells screened in the upper glacial aquifer (sites II, III, and V), and the Magothy aquifer (site III). The upper glacial aquifer sites illustrate the effect of hypothetical pumping rates on cones of depression, stream and shore discharge, and water-table mounding above the Smithtown clay. The Magothy aquifer site (site III) illustrates the effect of downward vertical gradient associated with the regional ground-water divide. Analysis of wells screened in heterogeneous zones is limited to wells screened in the Magothy aquifer; these analyses illustrate the effects of interference by public-supply wells, leakage through the Smithtown clay, and artesian conditions beneath the Gardiners Clay/Monmouth greensand.

\section{Homogeneous Zones of Diversion (Sites II and III)}

Site II.-Particle-tracking analysis of a hypothetical well at site II (Selden, model row 44, column 14, layer 1) assumed an aquifer porosity of 30 percent. Flowpaths and traveltime at 5-year intervals from the well to the point of entry (recharge location) under unstressed (nonpumping) conditions and at two pumping rates $\left(36,000\right.$ and $\left.72,000 \mathrm{ft}^{3} / \mathrm{d}\right)$ are depicted in plan view and vertical section in figure 25 . Eight starting points were uniformly distributed throughout the well cell and backtracked to the recharge 
locations. The contributing areas are delineated by (1) the endpoints of 8,000 particles backtracked from the well in plan view, and (2) by forward tracking of particles started at the water table in cells that were completely covered by backtracking endpoints in plan view and vertical section. The forward-tracking representation is a conservative estimate of the contributing area for the two pumping rates and includes additional representative pathlines and traveltimes. The maximum residence time of particles is about 10 years.

The column 14 simulation (fig. 22A) illustrates the unstressed regional flow vector. Site II (Selden) is in an area of recharge to the Magothy aquifer, and flow is mainly downward. Beneath layer 1, the Smithtown clay slightly restricts flow, and the water table is near the maximum altitude for the study area (fig. 16). Horizontal flow is southeastward. The simulation of pumping at this site illustrates the effect of a single stress that does not induce recharge at nearby flow boundaries. As described by equation 1, doubling the pumping rate causes the contributing area to double in size.

Site III.- This site is in the intermorainal zone at Ridge, 9 mi east of Selden (fig. 1). Particle-tracking analyses of wells in model row 44, column 47 and screened separately in Magothy aquifer layers 4 and 6 (fig. 26) assumed aquifer porosity of 30 percent. Recharge in this area reaches the Magothy aquifer without restriction by confining units. Total traveltimes for nonpumping and pumping conditions are tens of years for the layer- 4 well and hundreds of years for the layer- 6 well. Vertical hydraulic conductivity of the upper glacial aquifer layers 1 and 2 is about $250 \mathrm{ft} / \mathrm{d}$, and the horizontal-to-vertical anisotropy is 10:1; vertical hydraulic conductivity of Magothy layers 3 through 6 is $40 \mathrm{ft} / \mathrm{d}$, and the horizontal-to-vertical anisotropy is 100:1. Contributing areas are centered slightly north of the well's land-surface position and bounded on the north by the regional ground-water divide (fig. 22B). The land surface directly above the cell at row 44 , column 47 , is not part of the contributing area to the well screened in layer 6 but is part of the contributing area to the well screened in layer 4. Contributing areas do not surround the wellhead when its screened interval is deeper than model layer 4. The shape of the layer-4 contributing area is also more circular than that of the deep (layer 6) well. These differences occur because the stresses from deep pumping are dissipated over large volumes of the ground-water system before reaching the water table and thereby result in relatively flat cones of water-table depression and little convergence of shallow flow on the well location in the cell.
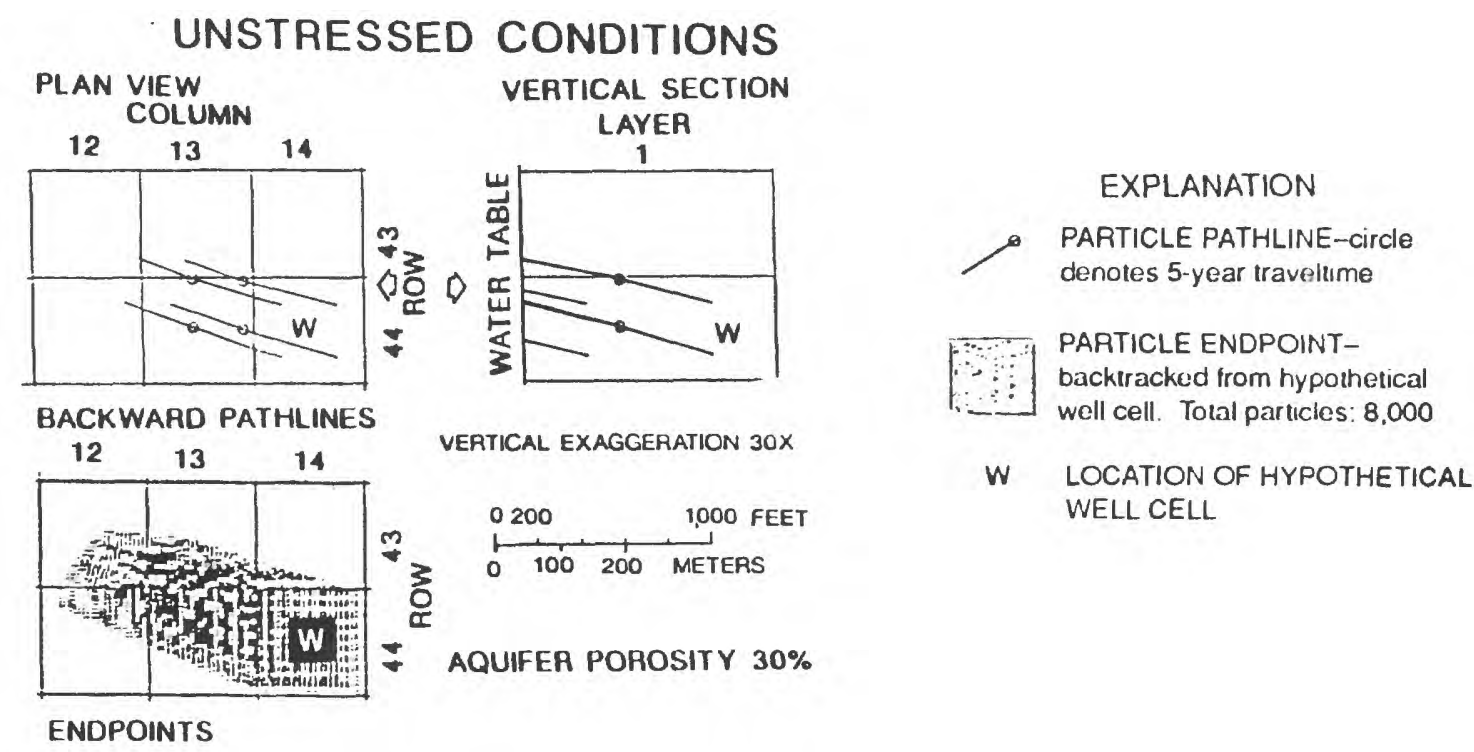

Figure 25A. Study-area model grid at site II (Selden), near the regional ground-water divide, showing results of particle-tracking analysis for a hypothetical well screened in model layer 1 under unstressed (nonpumping) conditions. (Orientation of vertical sections is shown in fig. 20). 


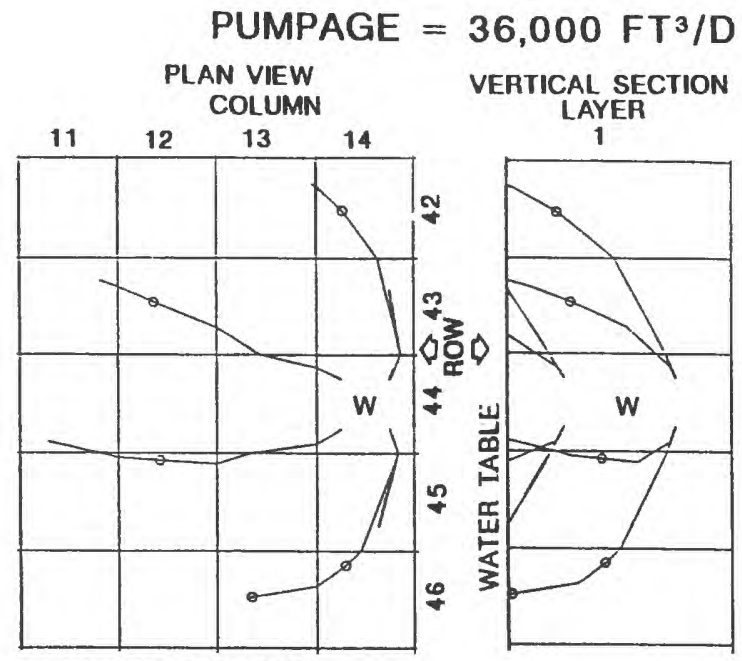

BACKWARD PATHLINES

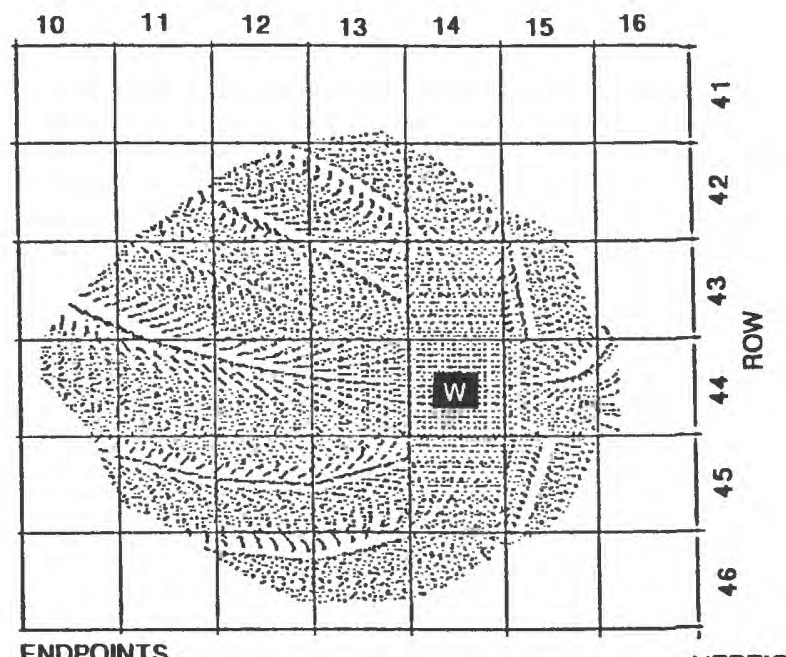

EXPLANATION

PARTICLE PATHLINE-circle denotes 5-year traveltime

PARTICLE ENDPOINT-backtracked from hypothetical well cell. Total particles: 8,000

W LOCATION OF HYPOTHETICAL WELL CELL

CAL SECTION

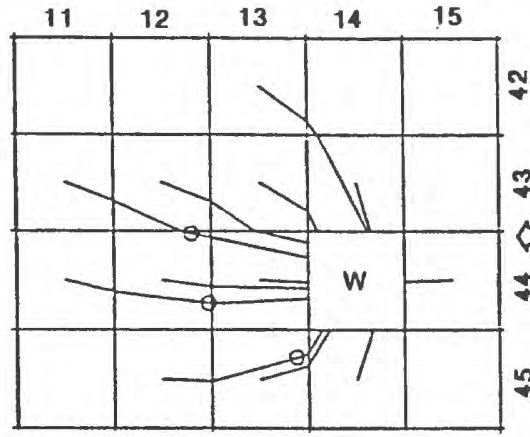

FORWARD PATHLINES

Figure 25B. Study-area model grid at site II (Selden), near the regional ground-water divide, showing results of particle-tracking analysis for a hypothetical well screened in model layer 1 at a pumping rate of 36,000 cubic feet per day. (Orientation of vertical sections is shown in fig. 20.) 

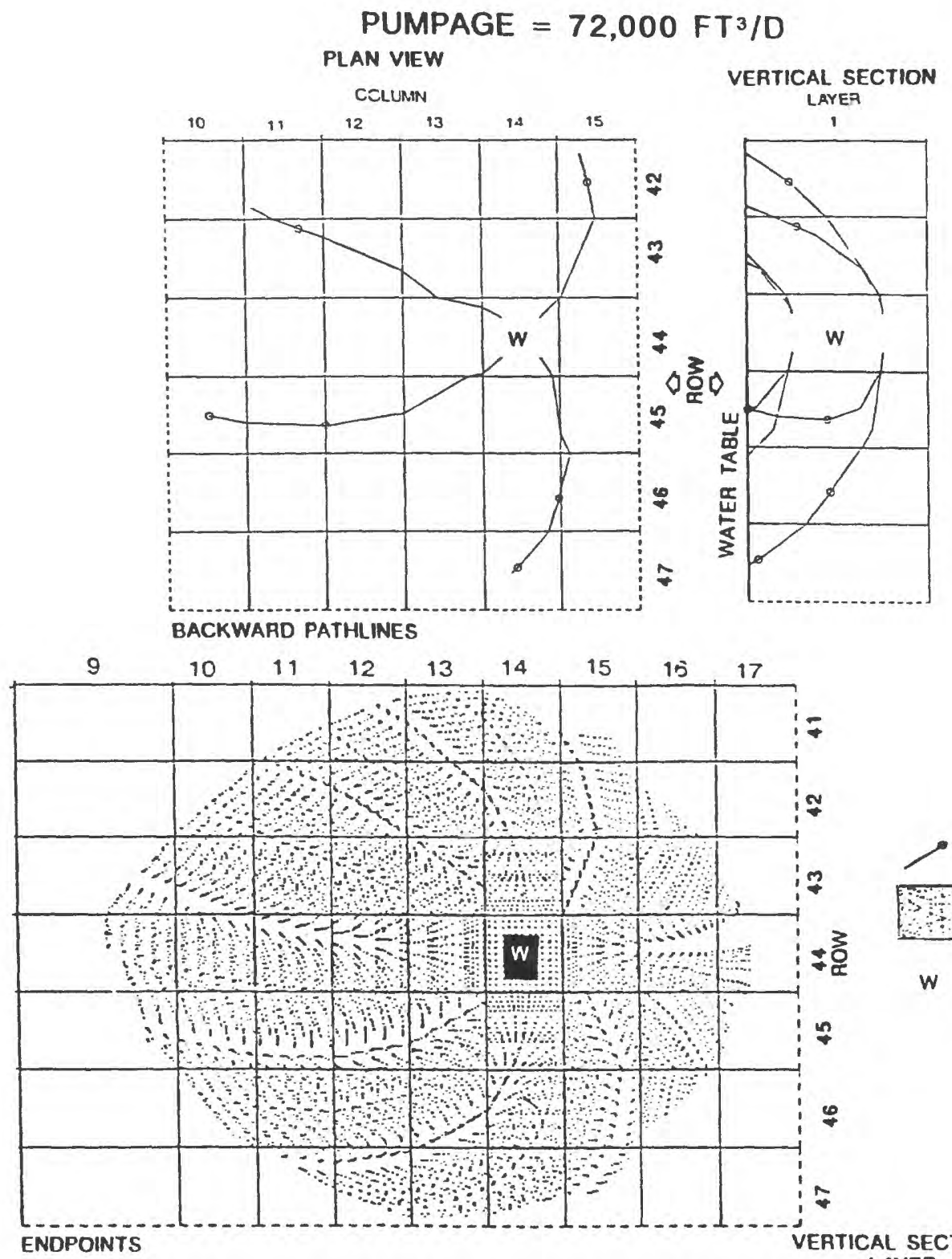

EXPLANATION

PARTICLE PATHLINE-circle denotes 5-year traveltime

PARTICLE ENDPOINTbacktracked from hypothencal well cell. Total particles. 8,000

LOCATION OF HYPOTHETICAL WELL CELL

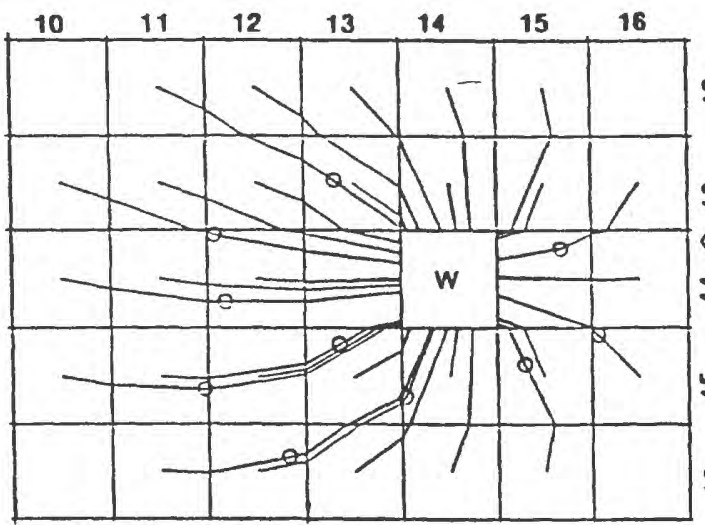

AL SECTION

LAYER

FOAWARD PATHLINES

Figure 25C. Study-area model grid at site II (Selden), near the regional ground-water divide, showing results of particle-tracking analysis for a hypothetical well screened in model layer 1 at a pumping rate of 72,000 cubic feet per day. (Orientation of vertical sections is shown in fig. 20.) 


\section{UNSTRESSED CONDITIONS}

PLAN VIEW COLUMN

$45 \quad 46 \quad 47$

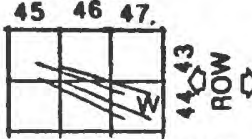

W VERTICAL SECTION

BACKWARD PATHLINES

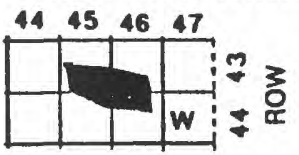

ENDPOINTS

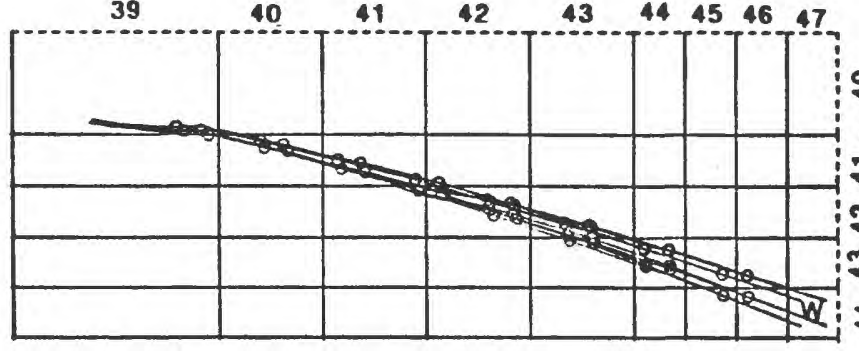

BACKWARD PATHLINES
VERTICAL SECTION

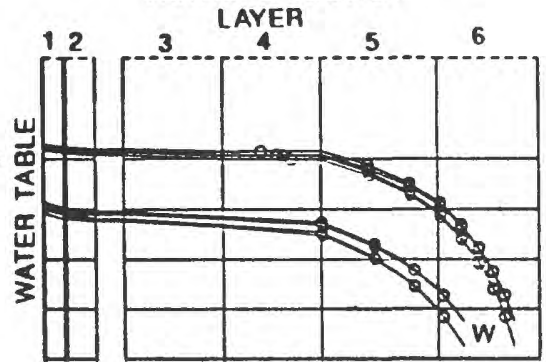

VERTICAL EXAGGERATION $5 X$

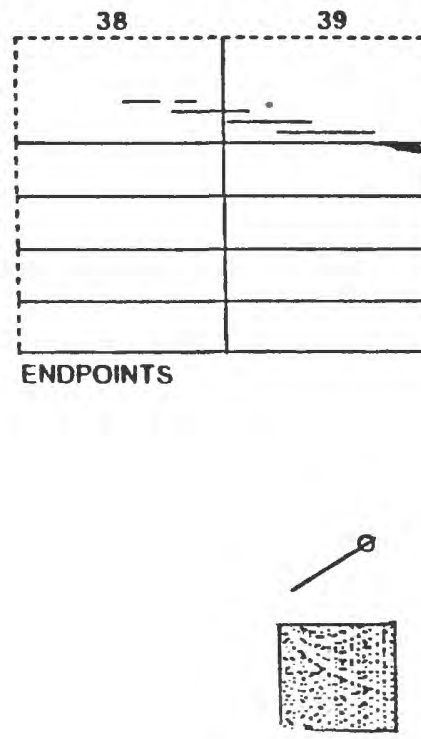

w

EXPLANATION

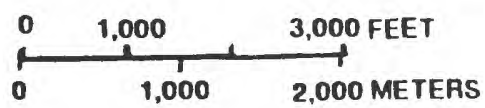

AQUIFER POROSITY $30 \%$

PARTICLE PATHLINE-. Circle denotes 5-year traveltime.

PARTICLE ENDPOINT -- Backtracked from hypothetical well cell. Total particles: 8,000 .

Figure 26A. Study-area-model grid at site III (Ridge), near the regional ground-water divide and adjacent to the Peconic River, showing results of particle-tracking analysis for a hypothetical well screened in model layer 4 (top) and layer 6 (bottom) under unstressed (nonpumping) conditions. (Orientation of vertical sections is shown in fig. 20.) 


\section{EXPLANATION}

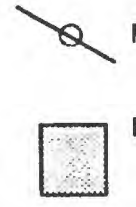

PARTICLE PATHLINE--circle denotes

5-year iraveltime.

PARTICLE ENDPOINT-backtracked from hypothetical well cell. Total number of particles: 8.000

W LOCATION OF HYPOTHETICAL WELL CELL
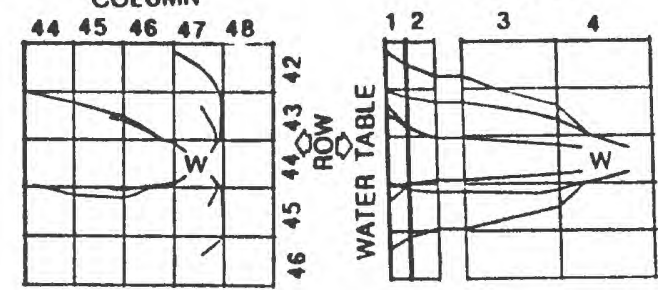

43

BACKWARD PATHLINES
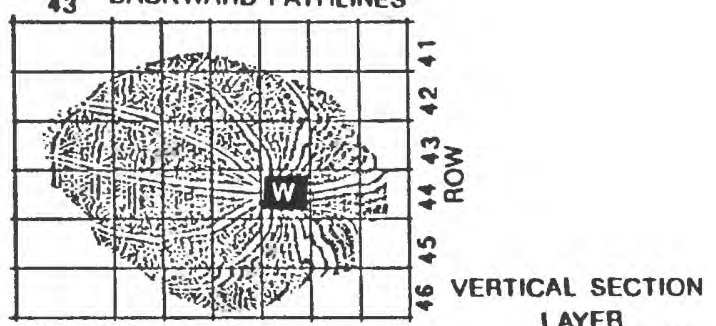

ENDPOINTS $46 \quad 47 \quad 48$

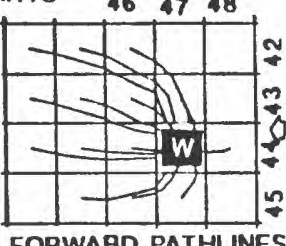
LAYEA
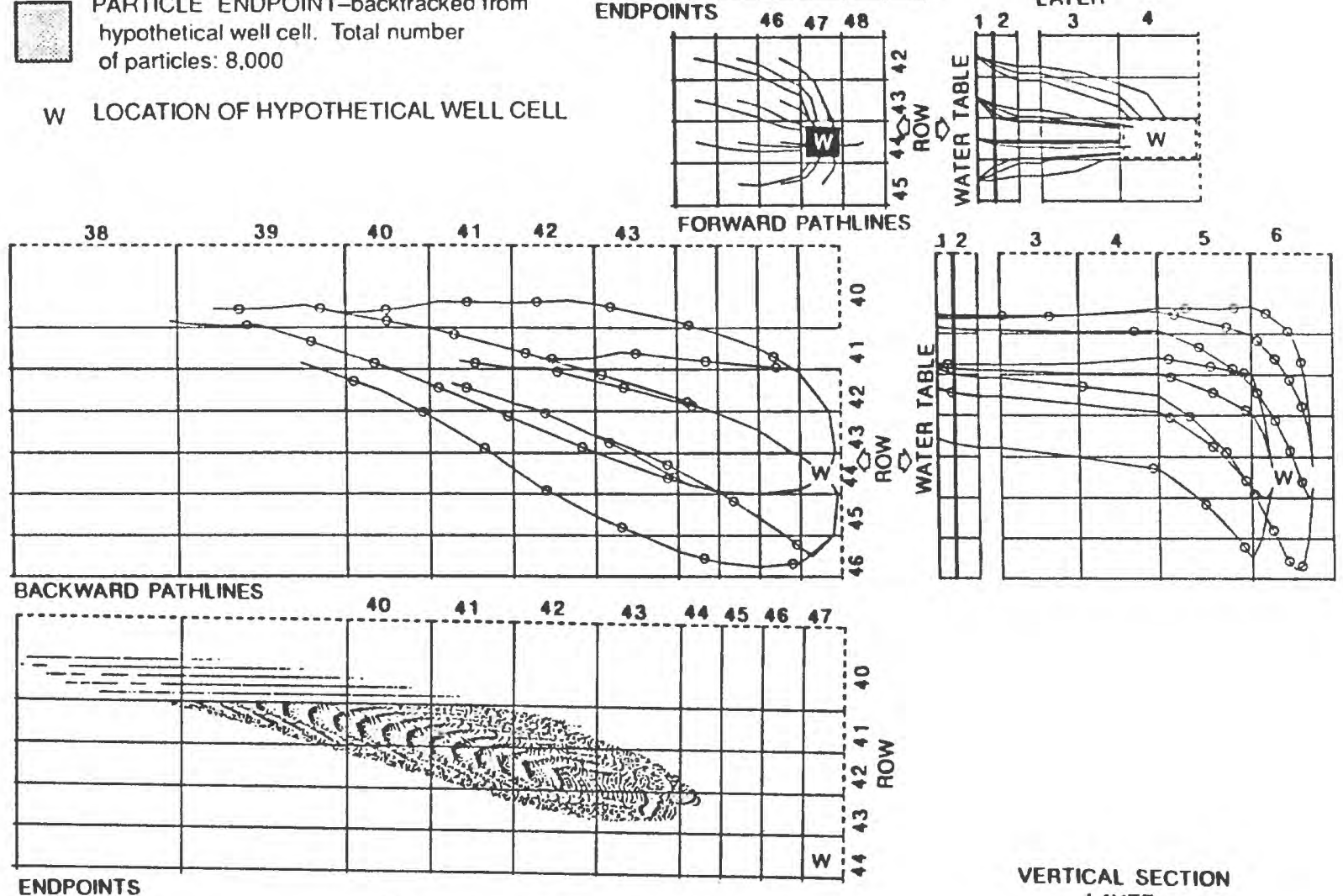

VEATICAL SECTION

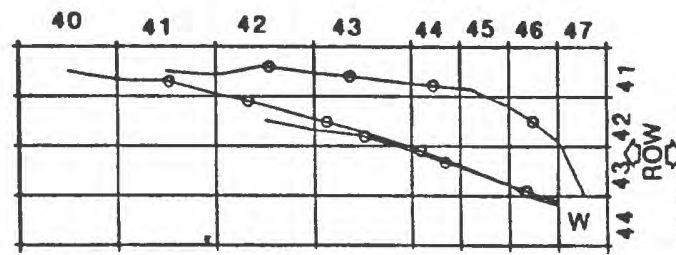

FOAWARD PATHLINES

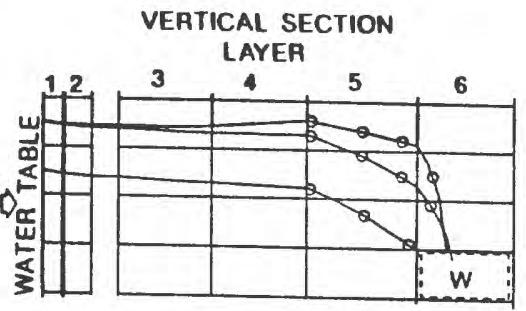

Figure 26B. Study-area-model grid at site III (Ridge), near the regional ground-water divide and adjacent to the Peconic River, showing results of particle-tracking analysis for a hypothetical well screened in model layer 4 (top) and layer 6 (bottom), at a pumping rate of 36,000 cubic feet per day . (Orientation of vertical sections is shown in fig. 20.) 


\section{PUMPAGE $=72,000 \mathrm{FT}^{3} / \mathrm{D}$ \\ SHALLOW WELL}
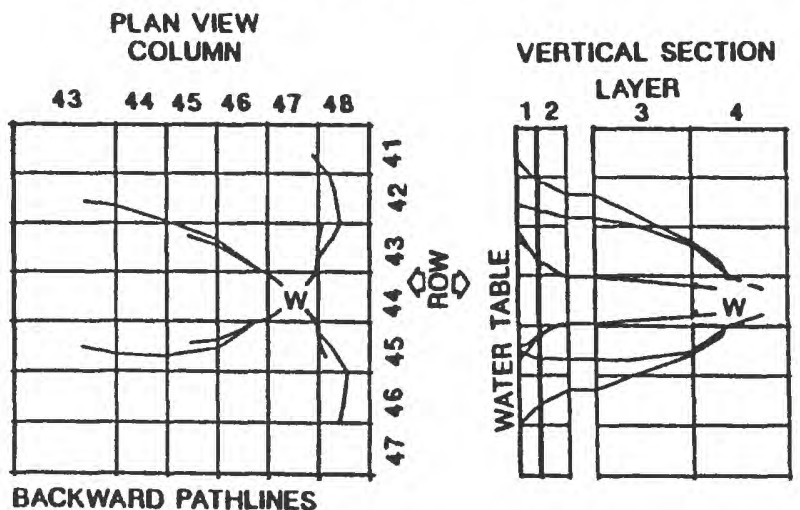

\section{BACKWARD PATHLINES}
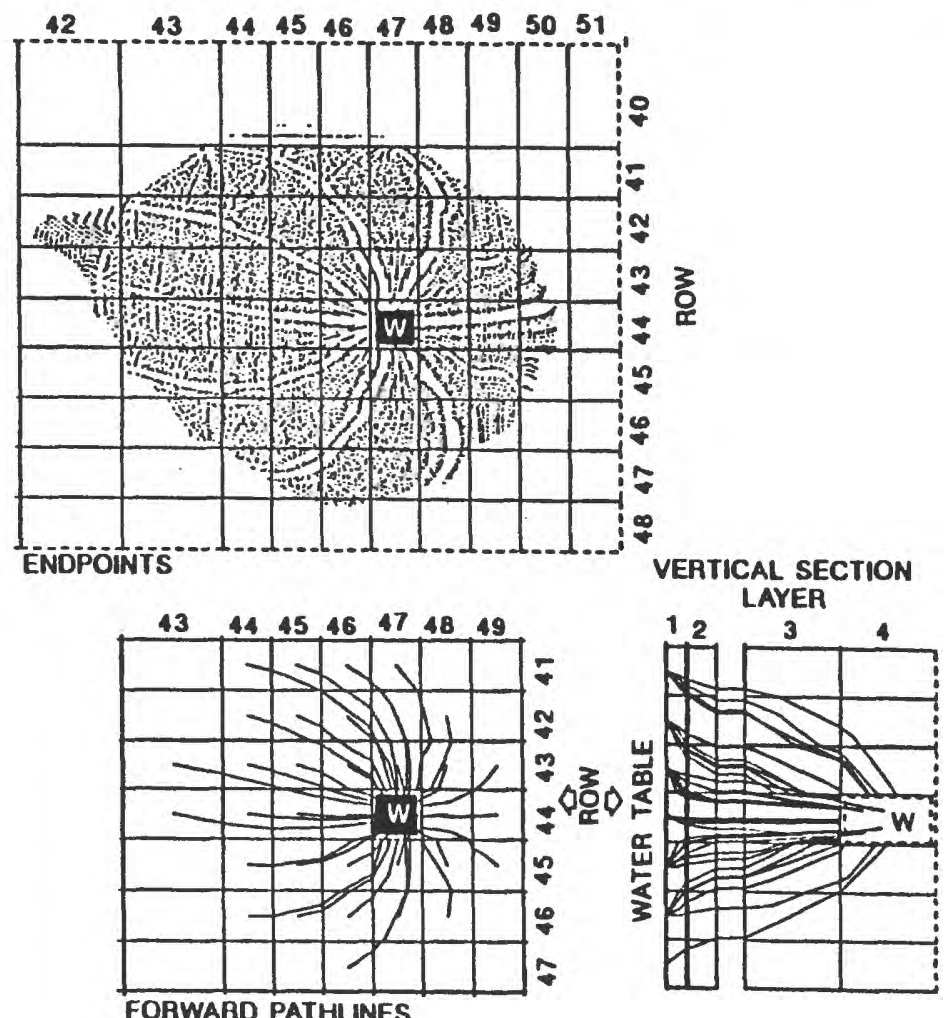

EXPLANATION

PARTICLE PATHLINE--circle denotes 5-year traveltime.

PARTICLE ENDPOINT-backtracked from hypothetical well cell. Total number of particles: 8,000

W LOCATION OF HYPOTHETICAL WELL CELL

Figure 26C. Study-area-model grid at site III (Ridge), near the regional ground-water divide and adjacent to the Peconic River, showing results of particle-tracking analysis for a hypothetical well screened in model layer 4 , at a pumping rate of 72,000 cubic feet per day. (Orientation of vertical sections is shown in fig. 20.) 


\section{Proximity to Streams (Sites III, IV)}

The Peconic, Carmans, Swan, and Patchogue Rivers were modeled with head-dependent flux boundaries (fig. 15). Total simulated discharge to the Patchogue and Peconic Rivers under nonpumping conditions, and the decrease in discharge that results from nearby hypothetical pumping at sites III (Ridge) and IV (Patchogue), are summarized in table 4. Pumping wells near rivers capture ground water that would have discharged to the rivers under nonpumping conditions and can induce infiltration of river water into the aquifer if pumpage is sufficient. The cones of depression resulting from two simulated pumping rates from a well screened in layer 1 at site III (Ridge), near the Peconic River, are illustrated in figure 27. The smaller drawdown near stream cells than at locations farther from the stream reflects the head dependence of the stream boundary. The streambed (drain) at row 48 , column 49 (fig. 27) is $48.6 \mathrm{ft}$ above sea level, and the simulated water-table altitude under nonpumping conditions is $49.1 \mathrm{ft}$; thus, ground water discharges to the stream. As shown in figure 27 , the drawdown at this cell for a pumping rate of $36,000 \mathrm{ft}^{3} / \mathrm{d}$ is about 0.3 $\mathrm{ft}$, which lowers the simulated water level to about $48.8 \mathrm{ft}$ and causes the simulated discharge to the Peconic River to decrease. The drawdown for a doubled pumping rate of $72,000 \mathrm{ft}^{3} / \mathrm{d}$ at the same cell is about $0.7 \mathrm{ft}$, which places the water level $(48.4 \mathrm{ft}$ ) below the streambed (drain) elevation and causes simulated discharge to cease. Although not simulated, this condition would result in induced infiltration from the stream.

A similar condition at site IV (Patchogue) was simulated, in which a pumping well was placed in layer 1 near the Patchogue River. The resulting decrease in ground-water discharge to streams at both sites (table 4) accounts for 33 to 44 percent of the flow necessary to balance the pumping stress; the rest is accounted for by a decrease in simulated discharge to constant-head and head-dependent flux boundaries throughout the entire model.

\section{Proximity to Shorelines (Sites I, V)}

Pumping wells near shorelines capture ground water that would have discharged to tidewater under nonpumping conditions. Reversal of boundary flow and subsequent capture of salty water can occur if pumpage is sufficiently high. Shorelines are represented as constant-head discharge boundaries. Discharges at critical constant-head cells near wells were examined; discharges under nonpumping conditions to the north-shore peninsula region of site I (Port Jefferson) and to the south-shore wetlands of site V (Moriches), and the decreases that result from two pumping rates, are given in table 4. Hypothetical pumpage of $72,000 \mathrm{ft}^{3} / \mathrm{d}$ did not generate any constant-head boundary inflows at shorelines.

Site $\mathrm{V}$ is near the southern shore of Long Island at Moriches. The particle-tracking analyses of a hypothetical well in model row 72, column 47 , layer 1 used an assumed aquifer porosity of 30 percent. Results of the nonpumping simulation (fig. 28) illustrate the flow system of the upper glacial aquifer (layers 1 and 2) in this area, which discharges without restriction by confining units into the Great South Bay. Total traveltimes under nonpumping conditions are 5 years or less. Results of the pumpage simulations $\left(36,000\right.$ and $\left.72,000 \mathrm{ft}^{3} / \mathrm{d}\right)$ indicate particles to be diverted from shoreline discharge toward well capture. Drawdown is evidenced by localized decreases in shoreline discharge, as given in table 4 . The maximum decrease ( 8 percent) occurs at row 71 , column 52, and results from the pumpage of $72,000 \mathrm{ft}^{3} / \mathrm{d}$. Total traveltimes for this pumping rate are 50 years or less. This well captures older particles than a shallow well screened in the deep recharge area (sites II and III). The regional flow regime is mainly horizontal near shorelines and the well captures particles from below that have traveled large horizontal distances

\section{Heterogeneous Zones of Diversion (Sites I, IV)}

Confining layers restrict ground-water movement. Measured heads in the Lloyd aquifer beneath the Raritan clay are at least $10 \mathrm{ft}$ lower than in the basal Magothy aquifer in the divide area, where the Lloyd aquifer is recharged, and have been as much as $20 \mathrm{ft}$ higher at Fire Island, south of Long Island in an area of Lloyd discharge. The restriction of upward flow through confining layers maintains the position of the saltwater interface seaward of Long Island, and particles that travel deep into the ground-water system, beneath confining units, can discharge several miles beyond the Long Island shore. 
The Gardiners Clay/Monmouth greensand (between the upper glacial and Magothy aquifers) and the Smithtown clay (within the upper glacial aquifer) extend only partly across the study area (fig. 4). Flow restriction by the Gardiners Clay/Monmouth greensand (where present) generates an offshore saltwater interface in the underlying Magothy aquifer; downward flow restriction by the Smithtown clay generates a water-table mound (fig. 16). Particle-tracking analyses of a hypothetical deep well at site IV (Patchogue) that taps the lowest Magothy model layer are given in figure 29, which shows the contributing area to be about $8 \mathrm{mi}$ north of the well site. Residence time of particles traveling from the water-table mound in this vicinity to the well is several hundred years (fig. 29). Flow paths to the well traverse the Smithtown confining layer (between aquifer model layers 1 and 2) near the well's contributing area; the Smithtown clay induces a 10-ft head difference. Above the Smithtown layer, the southernmost particles travel southward from the mound, then, after entering layer 2 , travel vertically downward to the lower Magothy.

The pathlines and contributing area at site I (northern shore, Port Jefferson) are affected by the operation of a deep-screened SCWA pumping well (table 5) in addition to water-table mounding above the Smithtown clay near the recharge area. Particle-tracking analysis of a hypothetical well at row 18 ,

Table 4. Simulated discharge to selected surface-water bodies under nonpumping conditions, and the decrease in discharge that results from two pumping rates at hypothetical wells screened in model layers 1 and 2 .

[ $\mathrm{ft}^{3} / \mathrm{d}$, cubic feet per day. Locations are shown in fig. 15.]

\begin{tabular}{|c|c|c|c|c|}
\hline $\begin{array}{c}\text { Initial } \\
\text { discharge } \\
\left(\mathrm{ft}^{3} / \mathrm{d}\right)\end{array}$ & $\begin{array}{l}\text { Model } \\
\text { layer }\end{array}$ & $\begin{array}{l}\text { Pumping } \\
\text { rate } \\
\left(\mathrm{ft}^{3} / \mathrm{d}\right)\end{array}$ & $\begin{array}{l}\text { Decrease in } \\
\text { stream discharge } \\
\left(\mathrm{ft}^{3} / \mathrm{d}\right)\end{array}$ & $\begin{array}{c}\text { Percentage of } \\
\text { total } \\
\text { pumpage }\end{array}$ \\
\hline \multicolumn{5}{|c|}{ A. Peconic River: RIDGE (SITE III) } \\
\hline \multirow[t]{4}{*}{$1,786,517$} & 1 & 36,000 & 15,036 & 42 \\
\hline & 2 & 36,000 & 15,002 & 42 \\
\hline & 1 & 72,000 & 27,334 & 38 \\
\hline & 2 & 72,000 & 27,324 & 38 \\
\hline \multicolumn{5}{|c|}{ B. Patchogue River: PATCHOGUE (SITE IV) } \\
\hline \multirow[t]{4}{*}{$1,332,685$} & 1 & 36,000 & 11,712 & 33 \\
\hline & 2 & 36,000 & 11,719 & 33 \\
\hline & 1 & 72,000 & 23,436 & 33 \\
\hline & 2 & 72,000 & 23,421 & 33 \\
\hline \multicolumn{5}{|c|}{ C. Long Island Sound: PORT JEFFERSON (SITE I) } \\
\hline \multirow[t]{4}{*}{199,125} & 1 & 36,000 & 9,003 & 25 \\
\hline & 2 & 36,000 & 8,941 & 25 \\
\hline & 1 & 72,000 & 18,898 & 26 \\
\hline & 2 & 72,000 & 18,787 & 26 \\
\hline \multicolumn{5}{|c|}{ D. Great South Bay: MORICHES (SITE V) } \\
\hline \multirow[t]{4}{*}{$1,161,219$} & 1 & 36,000 & 18,970 & 53 \\
\hline & 2 & 36,000 & 18,949 & 53 \\
\hline & 1 & 72,000 & 37,938 & 53 \\
\hline & 2 & 72,000 & 37,889 & 53 \\
\hline
\end{tabular}


column 14 , layer 6 , is shown in figure 30 . Forward-tracking analysis was infeasible because contributing areas do not cover the water table of any model cells. Simulated well pumpage of $43,030 \mathrm{ft}^{3} / \mathrm{d}$ from a SCWA production well at row 31, column 15, layer 5 acts as a weak sink (fig. 30). The water-budget and boundary flows for this cell indicate that well discharge is the dominant outflow and that particles entering this cell are most likely captured by the SCWA well. Particles traversing this cell probably represent a source of water to the SCWA well because about 90 percent of the inflow discharges to the well. Pathlines traversing cells adjacent to the weak-sink cell are affected by pumping but represent the source of water to the hypothetical well. Ring-shaped contributing areas to the hypothetical well are delineated by endpoints of 8,000 backtracked particles. The area inside the ring represents a conservative estimate of the contributing area to the SCWA pumping well because particles near the inside of the ring may have flowed through the weak sink.

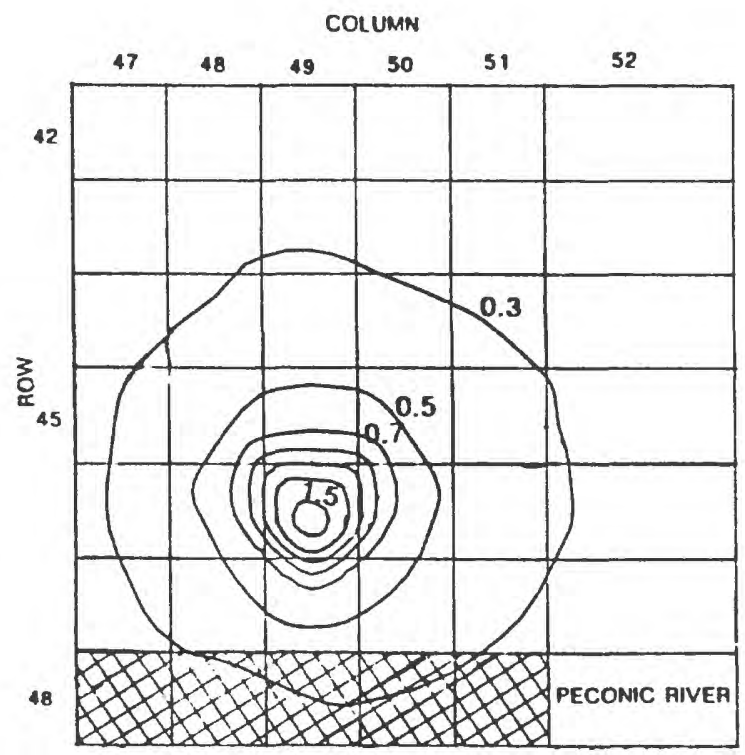

A. PUMPING RATE 36,000 CUBIC FEET PER DAY

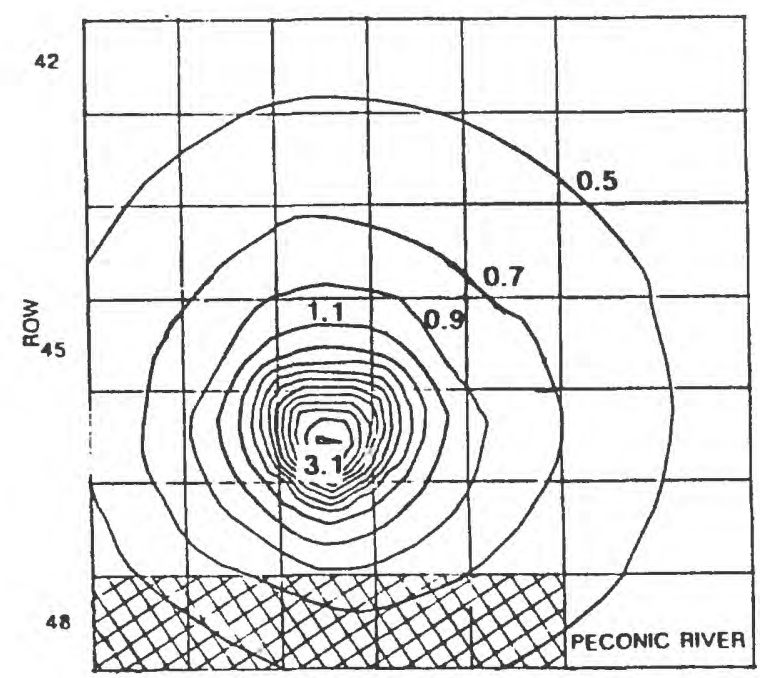

\section{EXPLANATION}

0.7

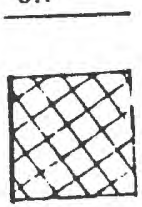

LINE OF EQUAL DRAWDOWN.

Contour interval 02 feet

STREAM BOUNDARY--Headdependent drain.

B. PUMPING RATE 72,000 CUBIC FEET PER DAY

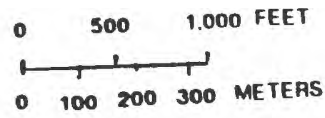

Figure 27. Cones of depression resulting from pumping rates of 36,000 and 72,000 cubic feet per day from model layer 1 at site III (Ridge), adjacent to the Peconic River. 


\section{UNSTRESSED CONDITIONS}
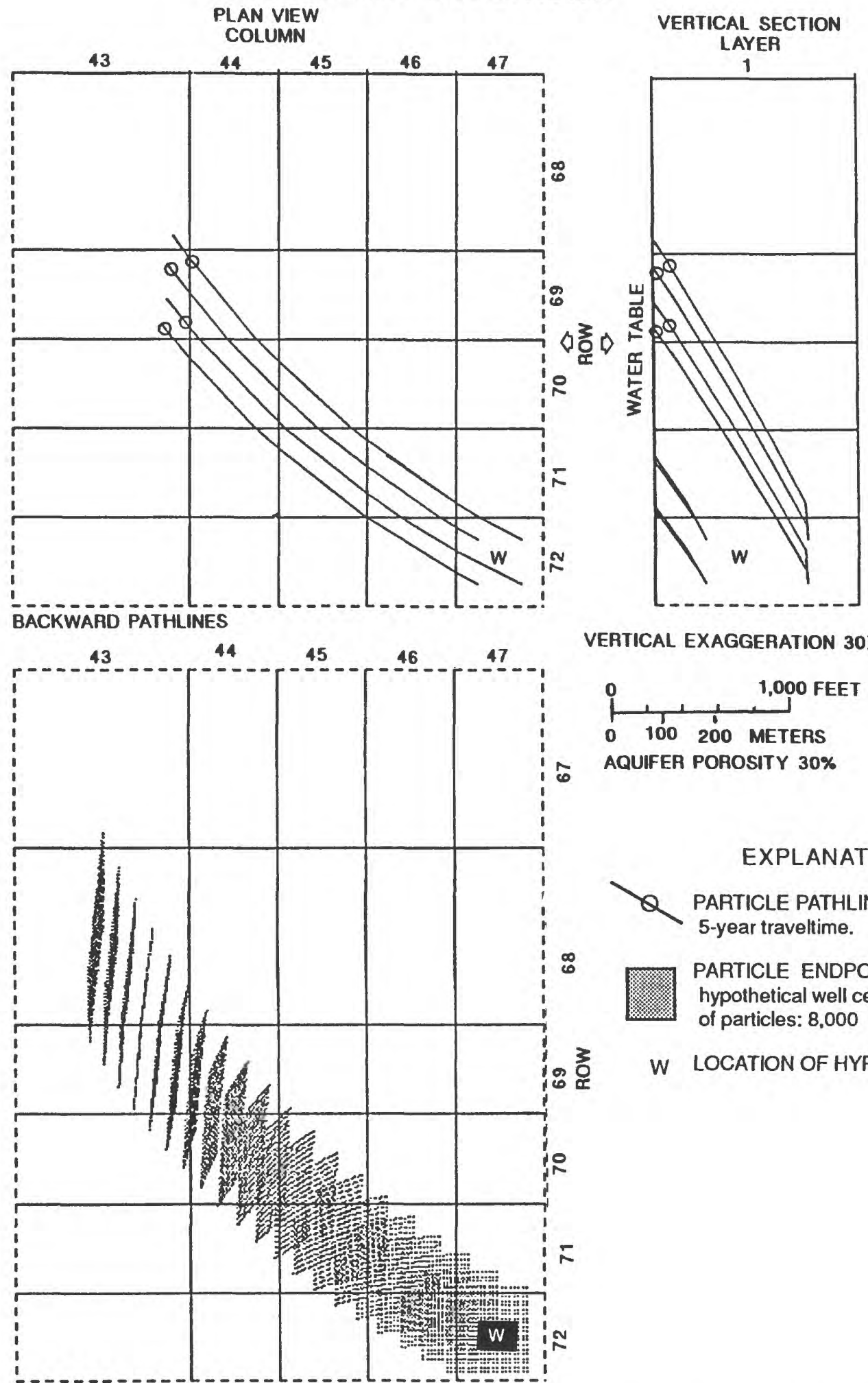

VERTICAL EXAGGERATION $30 X$
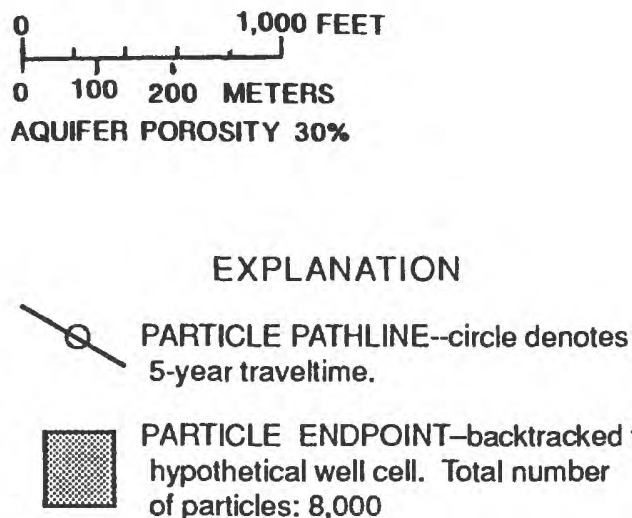

PARTICLE ENDPOINT-backtracked from hypothetical well cell. Total number of particles: 8,000

W LOCATION OF HYPOTHETICAL WELL

ENDPOINTS

Figure 28A . Study-area-model grid at site $V$ (Moriches), near the southern shore, showing results of particle-tracking analysis for a hypothetical well screened in model layer 1, under unstressed (nonpumping) conditions. (Orientation of vertical sections is shown in fig. 20.) 

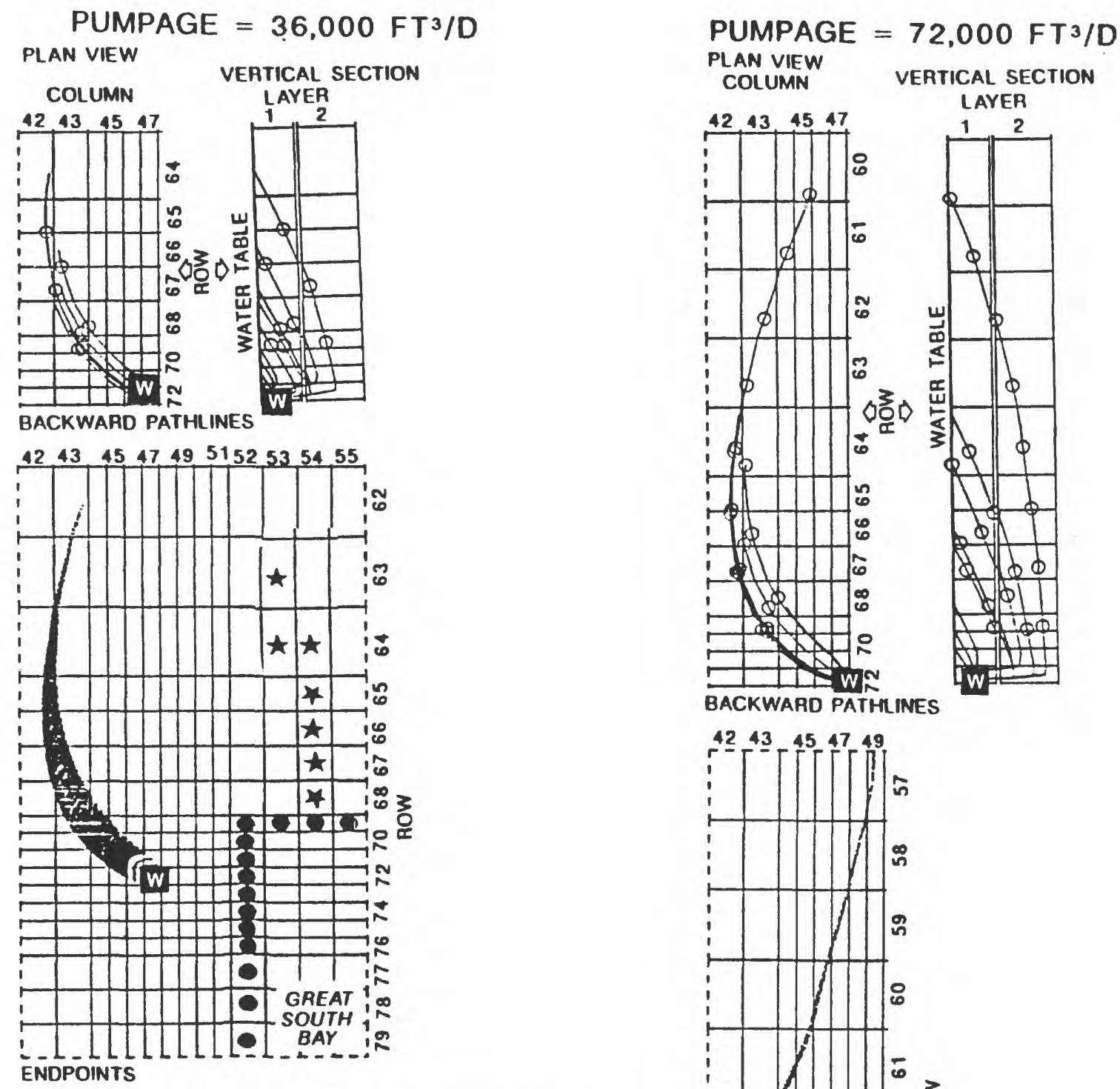

VERTICAL EXAGGERATION $30 X$
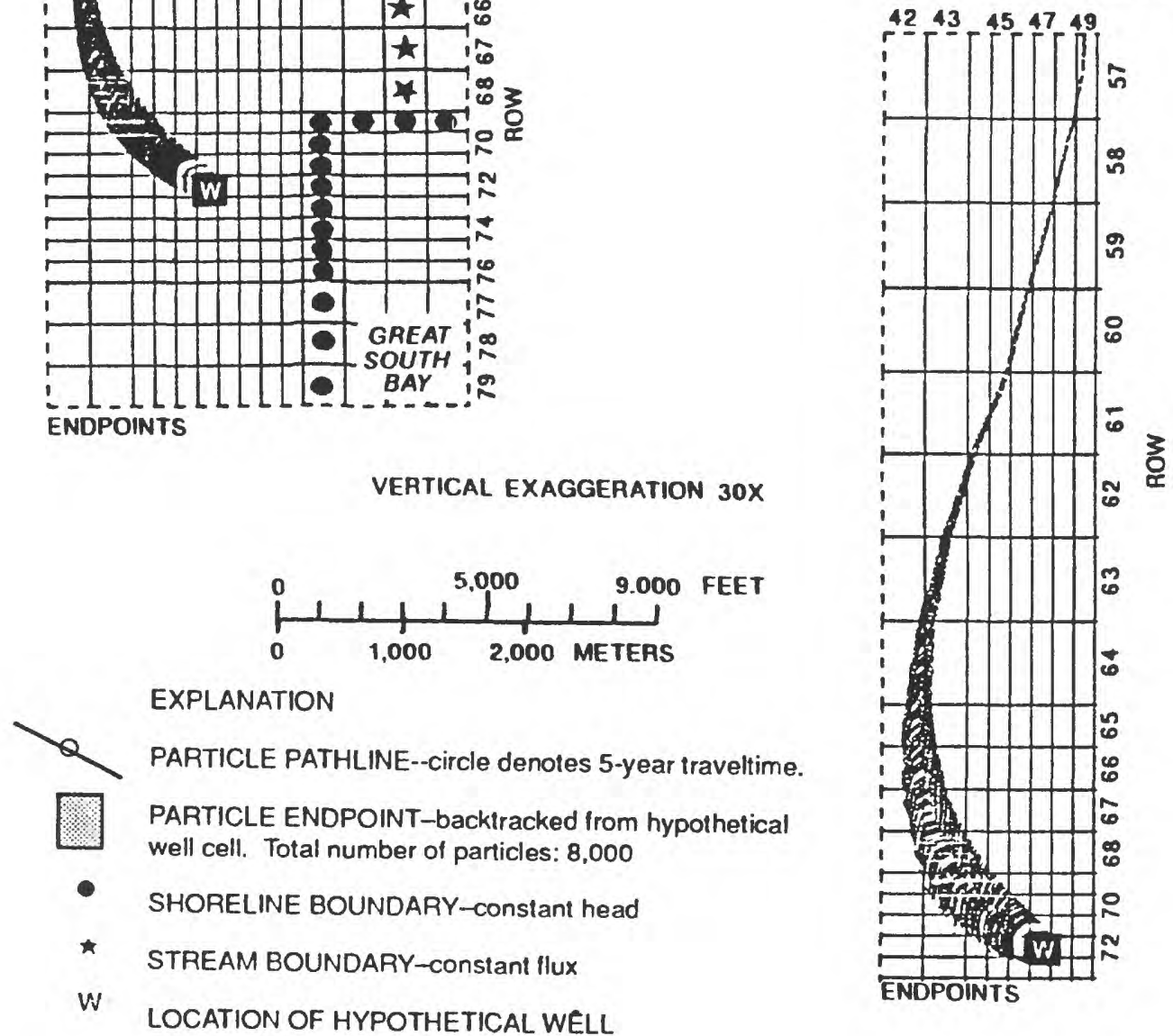

Figure 28B. Study-area-model grid at site $V$ (Moriches), near the southern shore, showing results of particle-tracking analyses for a hypothetical well screened in model layer 1 at pumping rates of 36,000 and 72,000 cubic feet per day. (Orientation of vertical sections is shown in fig. 20.) 


\section{UNSTRESSED CONDITIONS}

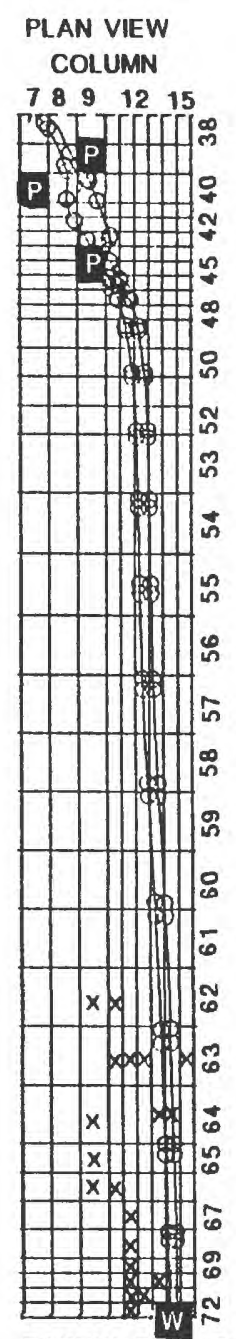

BACKWARD PATHLINES

VERTICAL EXAGGERATION $10 \mathrm{X}$

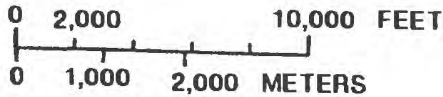

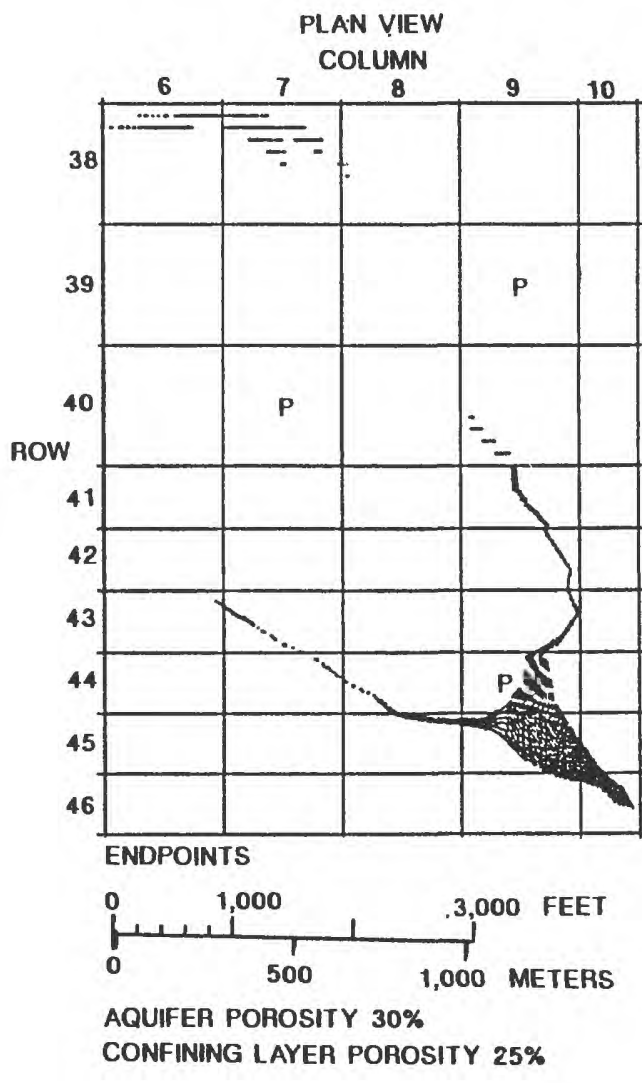

EXPLANATION

PARTICLE PATHLINE--Circle denotes 50 year traveltime.

PARTICLE ENDPOINT--Backtracked from hypothetical well cell. Total particles: 8,000 .

$x$

STREAM BOUNDARY-Head-dependent drain.

W LOCATION OF HYPOTHETICAL WELL CELL

P LOCATION OF SIMULATED PUBLICSUPPIY WELL

Figure 29A. Study-area-model grid at site IV (Patchogue), near the southern shore and adjacent to the Patchogue River, showing results of particle-tracking analysis for a hypothetical well screened in model layer 6 , under unstressed (nonpumping) conditions. (Orientation of vertical sections is shown in fig. 20.) 

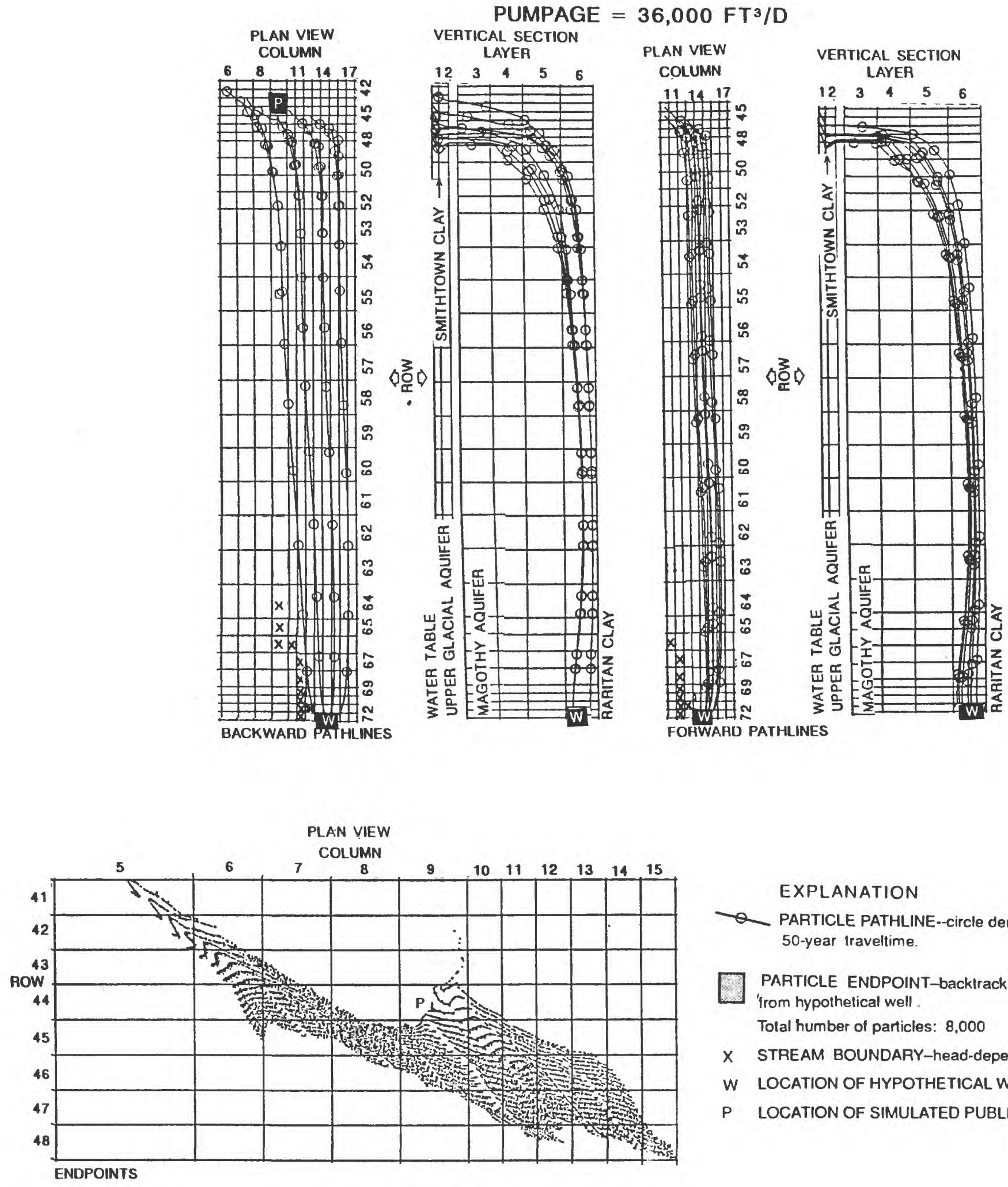

\section{EXPLANATION}

Q PARTICLE PATHLINE--circle denotes 50-year Iraveltime.

PARTICLE ENDPOINT-backtracked 'from hypothetical well.

Tolal humber of particles: 8,000

$X$ STREAM BOUNDARY-head-dependent drain

$W$ LOCATION OF HYPOTHETICAL WELL

P LOCATION OF SIMULATED PUBLIC-SUPPLY WELL

Figure 29B. Study-area-model grid at site IV (Patchogue), near the southern shore and adjacent to the Patchogue River, showing results of particle-tracking analysis for a hypothetical well screened in model layer 6 , at a pumping rate of 36,000 cubic feet per day. (Orientation of vertical sections is shown in fig. 20.) 


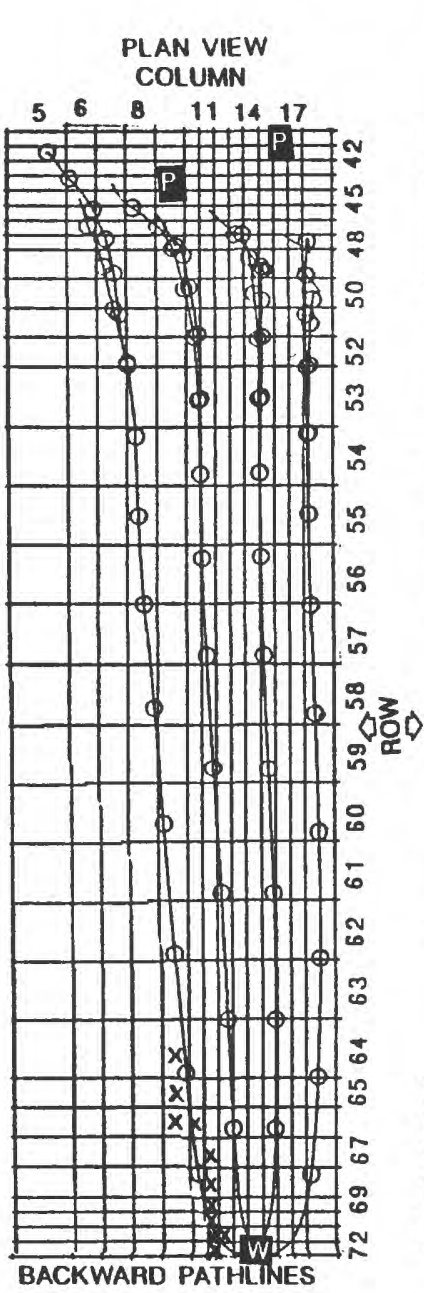

PUMPAGE $=72,000 \mathrm{FT}^{3} / \mathrm{D}$

VERTICAL SECTION

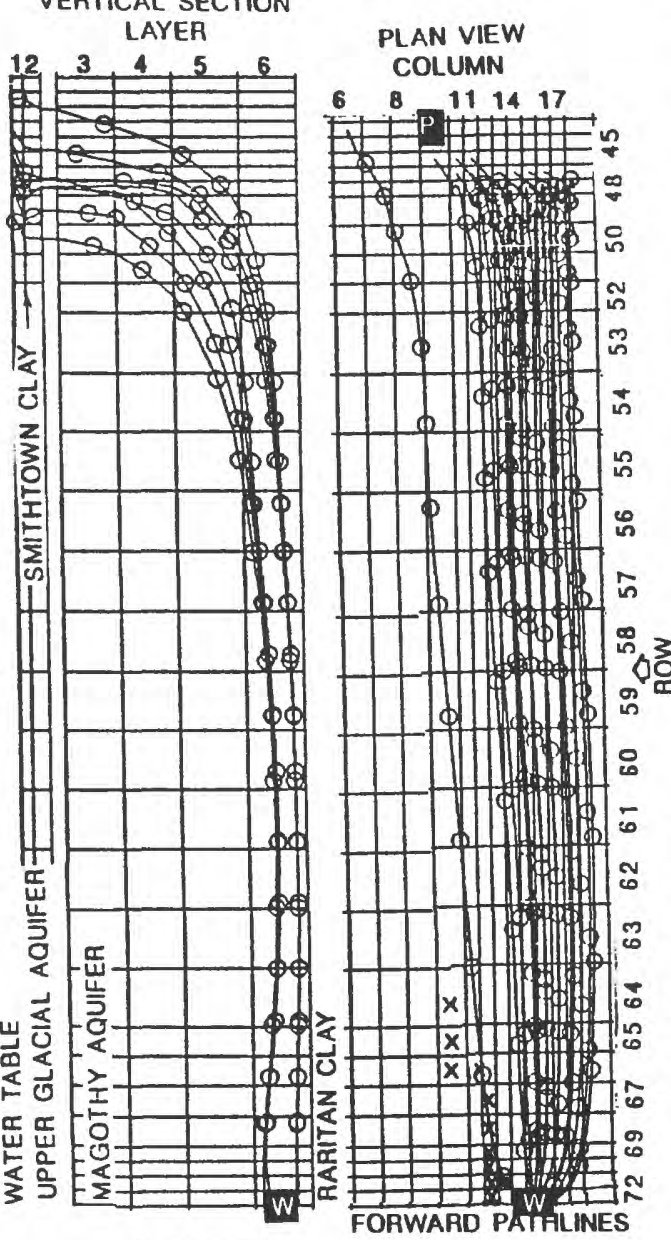

VERTICAL SECTION LAYER

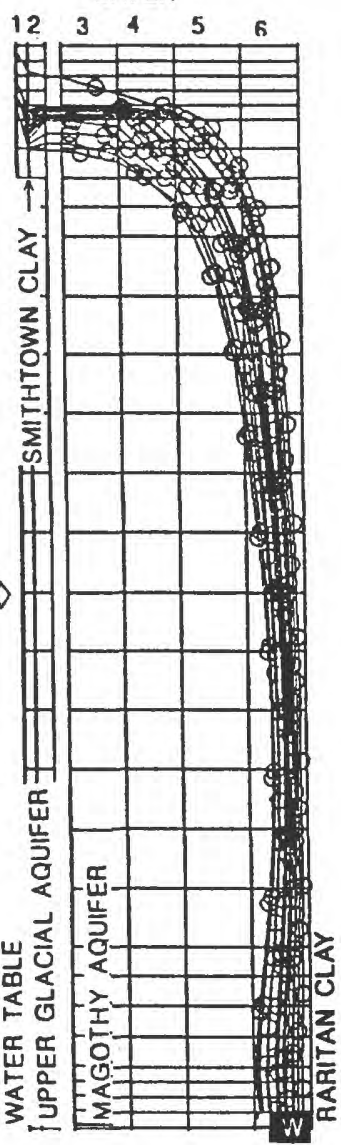

PLAN VIEW

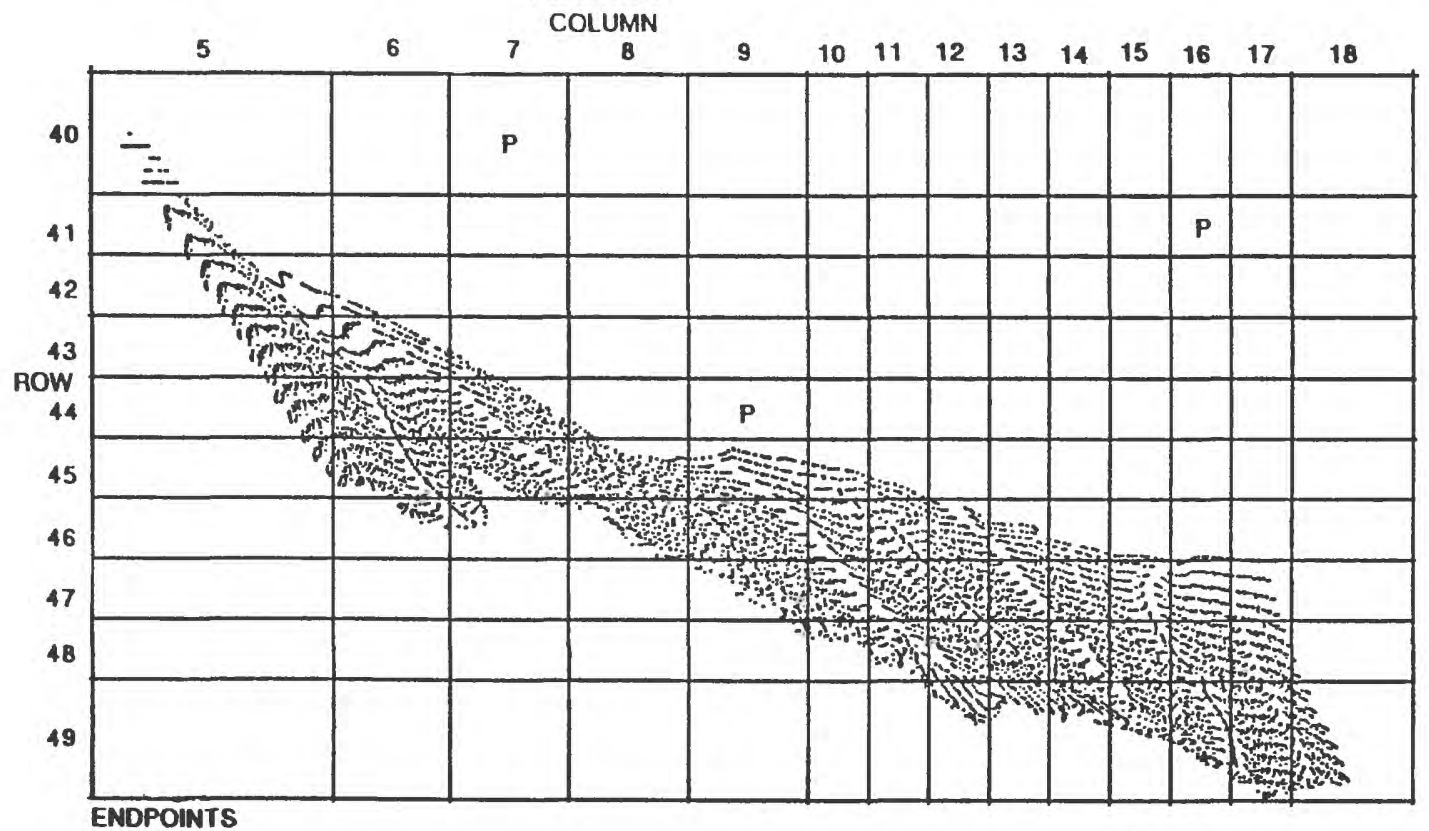

Figure 29C. Study-area-model grid at site IV (Patchogue), near the southern shore and adjacent to the Patchogue River, showing results of particle-tracking analysis for a hypothetical well screened in model layer 6 , at a pumping rate of 72,000 cubic feet per day. (Orientation of vertical sections is shown in fig. 20.) 


\section{UNSTRESSED CONDITIONS}

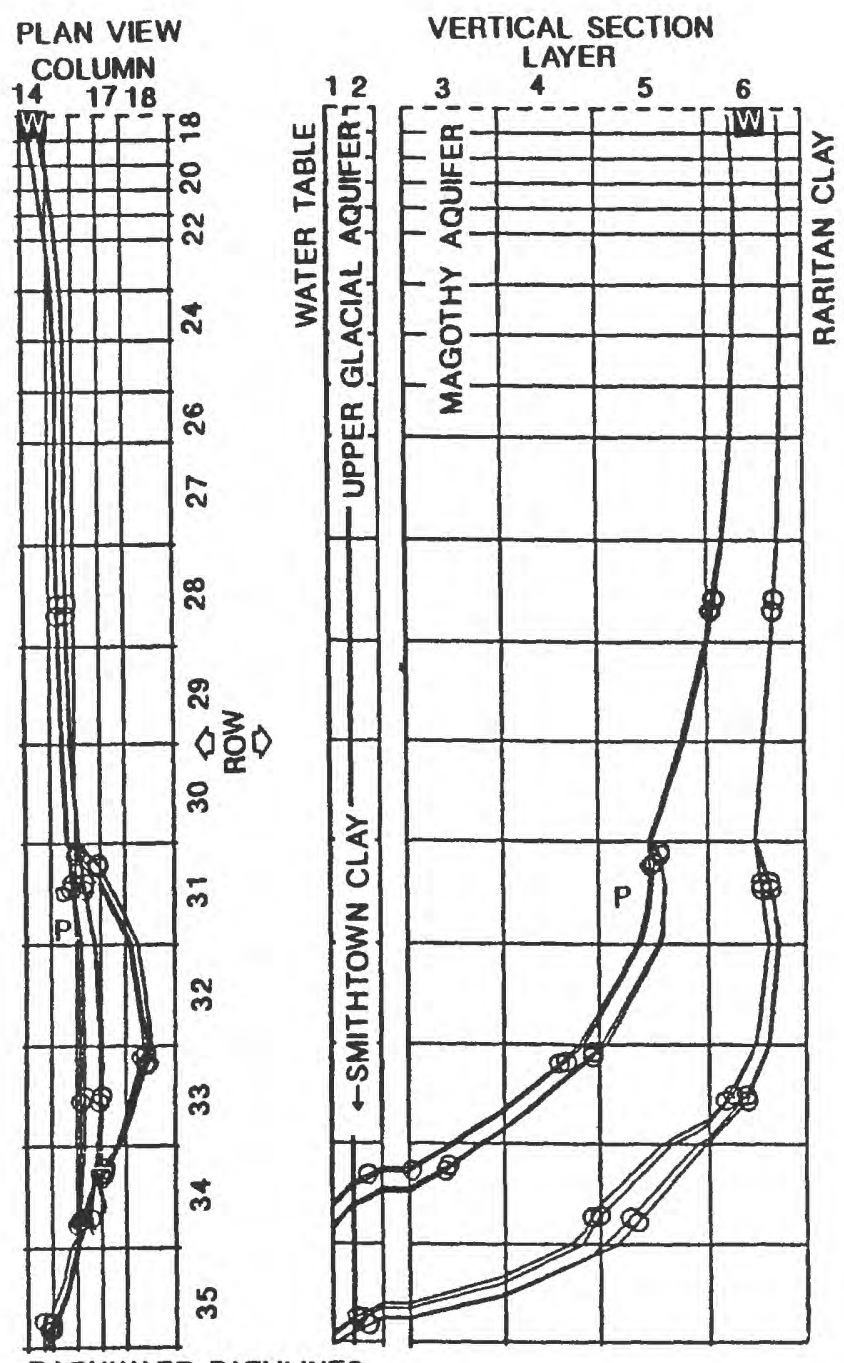

BACKWARD PATHLINES

VERTICAL EXAGGERATION $10 X$

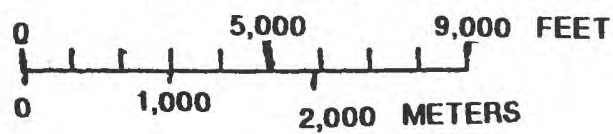

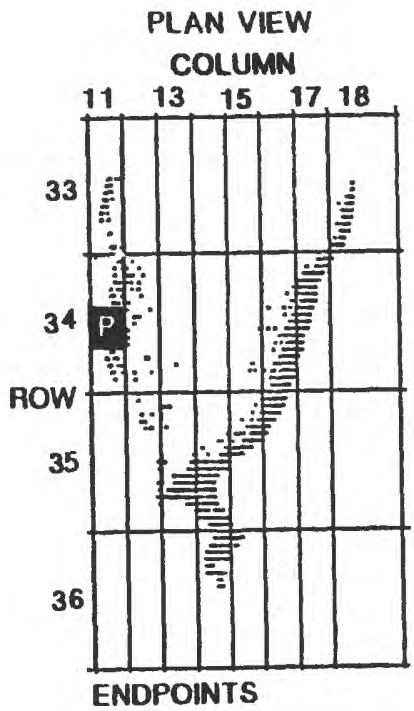

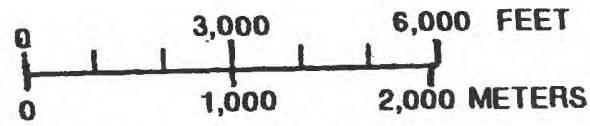

AQUIFER POROSITY $30 \%$

CONFINING LAYER POROSITY $25 \%$

\section{EXPLANATION}

PARTICLE PATHLINE-- Circle denotes 50-year traveltime.

PARTICLE ENDPOINT--Backtracked from hypothetical well cell. Total particles 8,000 .

W LOCATION OF HYPOTHETICAL WELL CELL

P LOCATION OF SIMULATED PUBLIC SUPPLY WELL

Figure 30A. Study-area-model grid at site I (Port Jefferson), on the northern shore, showing results of particle-tracking analysis for a hypothetical well screened in model layer 6, under unstressed (nonpumping) conditions. (Orientation of vertical sections is shown in fig. 20.) 


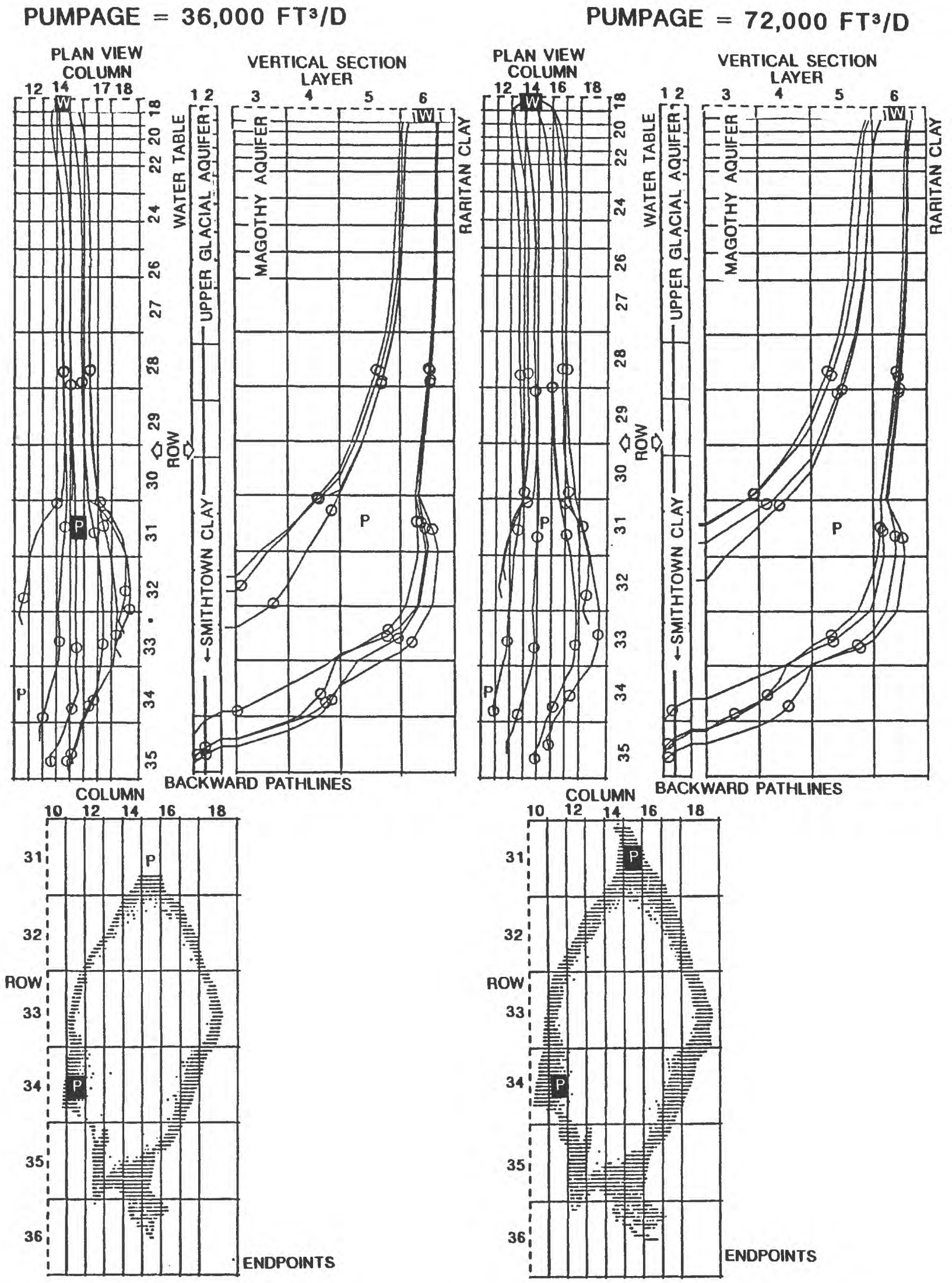

Figure 30B. Study-area-model grid at site I (Port Jefferson), on the northern shore, showing results of particle-tracking analysis for a hypothetical well screened in model layer 6 , for pumping rates of 36,000 and 72,000 cubic feet per day from model layer 6 . (Orientation of vertical sections is shown in fig. 20.) 


\section{SUMMARY AND CONCLUSIONS}

Simulation of ground-water flow and techniques for delineating contributing areas to wells were applied to five sites in central Long Island. A steady-state ground-water-flow model was developed and coupled to a regional model to provide appropriate resolution. Particle tracking was used to (1) delineate the regional flow regime along two north-south sections, and (2) to delineate contributing areas to a hypothetical well at each of five finely discretized sites. Traveltime intervals indicate that (1) maximum ground-water residence times in the regional flow regime are thousands of years and occur in a deep zone off the southern shore of Fire Island, and (2) residence time of water captured by a well depends on hydrogeologic setting and pumping rate.

The five sites were chosen to illustrate factors that affect the size, shape, location, and orientation of contributing areas. Separate particle-tracking analyses at each site were run under unstressed (nonpumping) conditions and at hypothetical pumping rates of 36,000 and $72,000 \mathrm{ft}^{3} / \mathrm{d}$. Well-screen depths were selected to illustrate effects of (1) discharges to streams (site III at Ridge, site IV at Patchogue, and site V at Moriches), (2) discharges to shoreline and wetlands (site I at Port Jefferson and site V at Moriches), and (3) nearby public-supply pumpage (site I at Port Jefferson). The effect of well-screen depth at two screendepths is illustrated in plots for site III at Ridge. Wells at sites I and IV tap zones of diversion wherein particles must travel through confining layers before being captured.

\section{REFERENCES CITED}

Buxton, H.T., and Reilly, T.E., 1985, Effects of sanitary sewering on ground-water levels and streams in Nassau County New York, part 2--Development and application of southwest Suffolk County model: U.S. Geological Survey Water-Resources Investigations Report 83-4209, 39 p.

1987, A technique for analysis of ground-water systems at regional and subregional scales applied on Long Island, New York, in Subitzky, Seymour (ed.), Selected papers in the hydrologic sciences 1986: U.S. Geological Survey Water-Supply Paper 2310, p. 129-142.

Buxton, H.T., Reilly, T.E., Pollock, D.W., and Smolensky, D.A., 1991, Particle tracking analysis of recharge areas on Long Island, New York: Groundwater, v. 29, no. 1, p. 63-71.

Doriski, T.P., 1986, Potentiometric-surface altitude of major aquifers on Long Island, New York, in 1983:

U.S. Geological Survey Water-Resources Investigations Report 85-4321, 4 pls., scale 1:125,000.

Franke, O.L., and Cohen, Philip, 1972, Regional rates of ground-water movement on Long Island, New York, in Geological Survey Research 1972: U.S. Geological Survey Professional Paper 800-C, p. C271-277.

Franke, O.L., and McClymonds, N.E., 1972, Summary of the hydrologic situation on Long Island, N.Y., as a guide to water-management alternatives: U.S. Geological Survey Professional Paper 627-F, 59 p.

Krulikas, R.K., and Koszalka, E.J., 1983, Geologic reconnaissance of an extensive clay unit in north-central Suffolk County, Long Island, New York: U.S. Geological Survey Water-Resources Investigations Report 82-4075, 9 p.

McClymonds, N.E., and Franke, O.L., 1972, Water-transmitting properties of aquifers on Long Island, New York: U.S. Geological Survey Professional Paper 627-E, 24 p.

McDonald, M.G., and Harbaugh, A.W., 1988, A modular three-dimensional finite-difference ground-water flow model: U.S. Geological Survey Techniques of Water-Resources Investigations, book 6, chap. A1, 586 p.

Morrissey, D.J., 1987, Estimation of the recharge area contributing water to a pumped well in a glacial-drift, river valley aquifer: U.S. Geological Survey Open-File Report 86-543, 59 p.

Peterson, D.S., 1987, Ground-water recharge rates in Nassau and Suffolk Counties, New York: U.S. Geological Survey Water-Resources Investigations Report 86-4181, 19 p. 
Pollock, D.W., 1989, Documentation of computer programs to compute and display pathlines using results from the U.S. Geological Survey modular three-dimensional finite-difference ground-water flow model: U.S. Geological Survey Open-File Report 89-381, 188 p.

Smolensky, D.A., Buxton, H.T., and Shernoff, P.K., 1989, Hydrologic framework of Long Island, New York: U.S. Geological Survey Hydrologic Investigations Atlas HA-709, 3 sheets, scale 1:250,000.

Soren, Julian, and Simmons, D.L., 1987, Thickness and hydrogeology of aquifers and confining units below the upper glacial aquifer on Long Island, New York: U.S. Geological Survey Water-Resources Investigations Report 864175,3 sheets, scale 1:125,000.

Spinello, A.G., Nakao, J.H., Flipse, W.J., Jr., and Carcaci, J.G., 1984, Water resources data, New York, water year 1983, volume 2-Long Island: U.S. Geological Survey Water Data Report NY-83-2, 248 p. 
Table 5. Public-supply-well locations in study-area model, Long Island, N.Y., and 1984-89 pumpage

[Pumpage data from Suffolk County Water Authority. Model rows and columns are shown in fig. 12; layers shown in fig. 13.

\begin{tabular}{|c|c|c|c|c|c|c|c|c|c|}
\hline \multirow{2}{*}{$\begin{array}{c}\text { Well } \\
\text { number }\end{array}$} & \multicolumn{3}{|c|}{ Model component } & \multirow{2}{*}{$\begin{array}{l}\text { Pumpage } \\
\text { (cubic feet } \\
\text { per day) }\end{array}$} & \multirow{2}{*}{$\begin{array}{c}\text { Well } \\
\text { number }\end{array}$} & \multicolumn{3}{|c|}{ Model component } & \multirow{2}{*}{$\begin{array}{l}\text { Pumpage } \\
\text { (cubic feet } \\
\text { per day) }\end{array}$} \\
\hline & Row & Column & Layer & & & Row & Column & Layer & \\
\hline S4372 & 23 & 9 & 2 & 8,584 & S68880 & 34 & 11 & $\overline{5}$ & 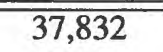 \\
\hline S8439 & 23 & 9 & 2 & 10,384 & S32325 & 34 & 19 & 3 & 37,962 \\
\hline S14612 & 23 & 35 & 2 & 865 & S32326 & 34 & 19 & 4 & 17,087 \\
\hline S34300 & 24 & 2 & 5 & 33,074 & S52490 & 34 & 19 & 4 & 38,330 \\
\hline S34301 & 24 & 2 & 6 & 40,417 & S51266 & 34 & 23 & 5 & 36,736 \\
\hline S57979 & 24 & 2 & 6 & 62,108 & S55502 & 34 & 23 & 5 & 40,666 \\
\hline S24663 & 26 & 16 & 3 & 36,043 & S47219 & 34 & 25 & 2 & 52,229 \\
\hline S22640 & 26 & 16 & 3 & 38,139 & S47310 & 34 & 25 & 5 & 38,322 \\
\hline S30088 & 26 & 29 & 3 & 40,426 & S37991 & 35 & 42 & 1 & 4,826 \\
\hline S38194 & 26 & 29 & 6 & 43,791 & S38784 & 36 & 3 & 5 & 24,240 \\
\hline S20838 & 26 & 33 & 1 & 6,248 & S36711 & 38 & 33 & 2 & 23,403 \\
\hline S20839 & 26 & 33 & 3 & 9,970 & S40161 & 38 & 33 & 2 & 41,373 \\
\hline S44640 & 26 & 33 & 2 & 23,636 & S49606 & 38 & 33 & 4 & 42,649 \\
\hline S61910 & 27 & 21 & 3 & 45,799 & S16309 & 39 & 9 & 2 & 31,837 \\
\hline S51953 & 27 & 21 & 3 & 68,942 & S21079 & 40 & 7 & 2 & 31,945 \\
\hline S68230 & 27 & 25 & 5 & 51,378 & S17438 & 40 & 7 & 2 & 42,681 \\
\hline S8895 & 27 & 61 & 2 & 697 & S70488 & 41 & 3 & 4 & 25,423 \\
\hline S2016 & 28 & 37 & 1 & 29,003 & S22547 & 41 & 3 & 1 & 17,947 \\
\hline S36166 & 29 & 1 & 4 & 30,031 & S35494 & 41 & 3 & 4 & 24,809 \\
\hline S57980 & 29 & 5 & 6 & 64,414 & S40331 & 41 & 16 & 4 & 102,104 \\
\hline S40837 & 29 & 5 & 3 & 64,457 & S40709 & 41 & 16 & 4 & 79,581 \\
\hline S14792 & 31 & 15 & 3 & 27,999 & S70459 & 41 & 16 & 4 & 48,800 \\
\hline S17689 & 31 & 15 & 4 & 24,058 & S23827 & 42 & 27 & 2 & 14,733 \\
\hline S23255 & 31 & 15 & 4 & 28,909 & S35494 & 41 & 3 & 4 & 24,809 \\
\hline S46928 & 31 & 15 & 5 & 43,030 & S23524 & 44 & 9 & 3 & 29,403 \\
\hline S34007 & 31 & 23 & 3 & 29,806 & S39347 & 51 & 2 & 1 & 25,472 \\
\hline S32180 & 31 & 23 & 3 & 25,406 & S42760 & 51 & 2 & 1 & 35,006 \\
\hline S36459 & 32 & 1 & 4 & 56,334 & S66496 & 51 & 2 & 6 & 72,748 \\
\hline S37301 & 32 & 1 & 3 & 58,065 & S32551 & 54 & 6 & 2 & 47,613 \\
\hline S58761 & 34 & 11 & 6 & 41,706 & S32552 & 54 & 6 & 2 & 48,513 \\
\hline S54473 & 54 & 6 & 2 & 38,683 & S21247 & 65 & 21 & 2 & 47,498 \\
\hline S60127 & 55 & 3 & 4 & 92,219 & S62022 & 65 & 21 & 3 & 59,257 \\
\hline S46400 & 55 & 9 & 2 & 97,012 & S37494 & 65 & 21 & 3 & 58,392 \\
\hline S53291 & 55 & 9 & 2 & 106,947 & S33826 & 65 & 29 & 2 & 18,254 \\
\hline S66881 & 55 & 9 & 2 & 48,173 & S42499 & 65 & 29 & 2 & 28,292 \\
\hline
\end{tabular}


Table 5. Public-supply-well locations in study-area model, Long Island, N.Y., and 1984-89 pumpage (continued)

\begin{tabular}{|c|c|c|c|c|c|c|c|c|c|}
\hline \multirow{2}{*}{$\begin{array}{c}\text { Well } \\
\text { number }\end{array}$} & \multicolumn{3}{|c|}{ Model component } & \multirow{2}{*}{$\begin{array}{l}\text { Pumpage } \\
\text { (cublc feet } \\
\text { per day) }\end{array}$} & \multirow{2}{*}{$\begin{array}{c}\text { Well } \\
\text { number }\end{array}$} & \multicolumn{3}{|c|}{ Model component } & \multirow{2}{*}{$\begin{array}{c}\text { Pumpage } \\
\text { (cublc feet } \\
\text { per day) }\end{array}$} \\
\hline & Row & Column & Layer & & & Row & Column & Layer & \\
\hline S47436 & 55 & 37 & 1 & 13,614 & S49018 & 65 & 29 & 4 & 27,006 \\
\hline S47437 & 55 & 37 & 1 & 4,570 & S71881 & 65 & 47 & 3 & 69,455 \\
\hline S47438 & 55 & 37 & 2 & 707 & S71882 & 65 & 47 & 3 & 81,761 \\
\hline S28819 & 57 & 4 & 2 & 53,674 & S27259 & 68 & 2 & 2 & 25,580 \\
\hline S29492 & 57 & 4 & 2 & 55,453 & S31913 & 68 & 2 & 2 & 22,937 \\
\hline S68666 & 57 & 4 & 2 & 71,737 & S47035 & 68 & 2 & 4 & 34,955 \\
\hline S56674 & 57 & 22 & 1 & 33,402 & S15037 & 71 & 23 & 1 & 23,905 \\
\hline S63256 & 57 & 22 & 1 & 34,916 & S20705 & 71 & 23 & 1 & 18,004 \\
\hline $\mathbf{S} 23440$ & 58 & 24 & 1 & 11,512 & S46712 & 71 & 58 & 2 & 7,125 \\
\hline S19408 & 58 & 26 & 2 & 22,855 & S46713 & 71 & 58 & 3 & 25,848 \\
\hline S17037 & 58 & 26 & 1 & 13,231 & S60486 & 77 & 8 & 3 & 37,297 \\
\hline S56038 & 60 & 57 & 2 & 26,045 & S871 & 80 & 2 & 2 & 16,368 \\
\hline S56039 & 60 & 57 & 2 & 1,043 & S872 & 80 & 2 & 2 & 20,156 \\
\hline S52944 & 61 & 29 & 2 & 58,194 & S9893 & 80 & 2 & 2 & 16,643 \\
\hline S52945 & 61 & 29 & 2 & 76,554 & S28408 & 80 & 2 & 3 & 28,158 \\
\hline S38320 & 62 & 5 & 2 & 42,505 & S1331 & 81 & 29 & 1 & 17,696 \\
\hline S42761 & 62 & 5 & 3 & 42,290 & $\mathbf{S} 14710$ & 81 & 29 & 2 & 21,274 \\
\hline S38321 & 62 & 5 & 3 & 45,351 & S69364 & 81 & 29 & 4 & 26,773 \\
\hline S53074 & 62 & 5 & 2 & 43,245 & S18729 & 82 & 39 & 3 & 28,650 \\
\hline S66183 & 63 & 4 & 4 & 56,728 & S52943 & 82 & 39 & 2 & 12,356 \\
\hline S66184 & 63 & 4 & 3 & 49,797 & $S 27440$ & 93 & 9 & 4 & 7,562 \\
\hline S54730 & 63 & 4 & 3 & 48,880 & $\mathrm{~S} 22880$ & 95 & 1 & 4 & 16,226 \\
\hline S59744 & 63 & 4 & 3 & 83,283 & S47024 & 84 & 66 & 3 & 34,776 \\
\hline S71785 & 63 & 24 & 3 & 111,924 & S70104 & 18 & 30 & 2 & 10 \\
\hline S28767 & 65 & 21 & 2 & 42,777 & S8736 & 18 & 30 & 3 & 520 \\
\hline S4152 & 22 & 34 & 2 & 1,497 & S71715 & 29 & 47 & 1 & 45,028 \\
\hline S11866 & 22 & 34 & 2 & 1,197 & S32563 & 30 & 61 & 1 & 6,072 \\
\hline S55101 & 23 & 35 & 2 & 736 & S89133 & 31 & 63 & 4 & 788 \\
\hline S65290 & 26 & 29 & 6 & 57,159 & S23772 & 31 & 64 & 1 & 2,578 \\
\hline S5565 & 28 & 37 & 2 & 34,675 & S35467 & 31 & 64 & 1 & 3,808 \\
\hline S8265 & 28 & 41 & 2 & 38,131 & S47310 & 34 & 25 & 6 & 38,322 \\
\hline S11464 & 28 & 42 & 1 & 12,816 & S52451 & 34 & 25 & 2 & 35,609 \\
\hline S50222 & 28 & 42 & 2 & 19,168 & S43117 & 36 & 3 & 5 & 27,710 \\
\hline S65341 & 28 & 42 & 1 & 92,485 & S42505 & 44 & 21 & 2 & 87,633 \\
\hline S40838 & 29 & 6 & 3 & 56,079 & S42504 & 44 & 21 & 2 & 164,471 \\
\hline
\end{tabular}

